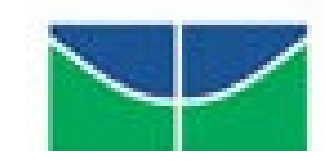

\author{
UNIVERSIDADE DE BRASÍLIA - UnB \\ Centro de Excelência em Turismo \\ Pós-graduação Lato Sensu Gestão de Negócios em Turismo
}

\begin{abstract}
A RELAÇÃO ENTRE CLIMA ORGANIZACIONAL E EXCELÊNCIA NO ATENDIMENTO: UM ESTUDO COMPARATIVO ENTRE O QUALITY RESORT LAKESIDE E O METROPOLITAN FLAT
\end{abstract}

\author{
Por \\ RICARDO CAIAFA \\ Orientador: Professor Dr. Gilson Borda
}

Brasília-2007 


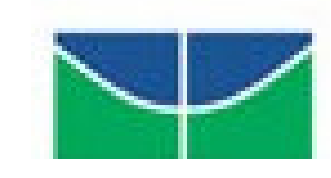

\author{
UNIVERSIDADE DE BRASÍLIA - UnB \\ Centro de Excelência em Turismo \\ Pós-graduação Lato Sensu em Gestão Empreendedora
}

\title{
A RELAÇÃO ENTRE CLIMA ORGANIZACIONAL E EXCELÊNCIA NO ATENDIMENTO: UM ESTUDO COMPARATIVO ENTRE O QUALITY RESORT LAKESIDE E O METROPOLITAN FLAT
}

\author{
Por \\ Ricardo Caiafa \\ Orientador: Professor Dr. Gilson Borda
}

Monografia apresentada ao Centro de Excelência em Turismo - CET, da Universidade de Brasília - UnB, como requisito parcial à obtenção do grau de Especialista em Gestão de Negócios em Turismo. 
CAIAFA, Ricardo.

A relação entre clima organizacional e excelência no atendimento: um estudo comparativo entre o Quality Resort Lakeside e o Metropolitan Flat / Ricardo Caiafa - Brasília-2007. xv, 106f.: il.

Monografia (especialização) - Universidade de Brasília, Centro de Excelência em Turismo, 2007.

Orientador: Professor Gilson Borda. 


\title{
$\Psi$ \\ UNIVERSIDADE DE BRASÍLIA - UnB \\ Centro de Excelência em Turismo \\ Pós-graduação Lato Sensu \\ Curso de Especialização em Gestão de Negócios em Turismo
}

\author{
RICARDO CAIAFA
}

Aprovado por:

Orientador: Dr. Professor Gilson Zehetmeyer Borda

Professor(a): MSc Walter Eustáquio Ribeiro

Professor(a): MSc Shirley Pontes

Monografia apresentada ao Centro de Excelência em Turismo - CET, da Universidade de Brasília - UnB, como requisito parcial à obtenção do grau de Especialista em Gestão de Negócios em Turismo.

Brasília, 27 de Agosto de 2007. 


\section{DEDICATÓRIA}

Aos meus pais pelo estímulo e compreensão.

A todos que, direta ou indiretamente, contribuíram para conclusão de mais esta etapa em minha vida. 


\section{AGRADECIMENTOS}

A Deus, aos meus familiares, aos professores e amigos, sem os quais não teríamos conseguido cumprir este desafio. Em especial ao meu orientador, que tanto contribuiu na concretização deste trabalho. 
"O futuro é construído pelas nossas decisões diárias, inconstantes e mutáveis, e cada evento influencia todos os outros." 


\section{RESUMO}

O presente trabalho tem como objeto de estudo a relação entre o Clima Organizacional e a qualidade do atendimento no Quality Resort Lakeside e no Metropolitan Flat, ambos administrado pela Rede Atlantica Hotels. O foco principal da pesquisa são os caracteres de satisfação com o trabalho, incidentes sobre o clima organizacional no ambiente de trabalho. Parte-se do pressuposto que o índice de satisfação do cliente dos hotéis pesquisados esteja relacionado diretamente com a qualidade do clima organizacional. Acredita-se que o funcionário bem disposto e motivado para o trabalho influencia positivamente o clima organizacional da empresa e, dessa forma, determina tanto a qualidade dos serviços realizados e a produtividade como também a qualidade do atendimento ao cliente. O estudo realiza uma incursão no conceito do Clima Organizacional buscando entender essa prática e suas respectivas características. Interpretar os aportes teórico-metodológicos concebidos pelos principais autores que buscam compreender o Clima Organizacional na sua origem e nos seus aspectos práticos. O estudo identifica e evidencia, por meios quantitativos, fundamentados em pesquisa bibliográfica e avaliação do clima organizacional do Quality Resort Lakeside e Metropolitan Flat, algumas especificidades dessa prática, como por exemplo, seus principais conceitos, os objetivos dessa disciplina e sua eficácia na aplicação prática de seus princípios. Nesse sentido, foi realizada uma pesquisa com 34 funcionários do hotel Lakeside e com 24 funcionários do Hotel Metropolitan, em cargos e funções variados, no intuito de equacionar as variáveis mais elementares e, assim, poder apreciar até que ponto o clima organizacional tem influenciado a qualidade do atendimento nos hotéis pesquisados. Portanto, foi aplicado um questionário de avaliação do clima organizacional e os resultados demonstraram nível satisfatório de clima organizacional nos dois hotéis pesquisados, sugerindo influência do clima organizacional sobre a qualidade no atendimento. A pesquisa, portanto, revelou que o clima organizacional do Lakeside e do Metropolitan se deve, sobretudo, aos benefícios oferecidos aos colaboradores, aos treinamentos e programas de incentivo, bem como uma política de recursos humanos voltada para a satisfação dos colaboradores no ambiente de trabalho. A partir dessas ações, os colaboradores motivados e satisfeitos, aparentemente, interagem de forma satisfatória com os clientes dos hotéis, influenciando positivamente a percepção dos hóspedes em relação à qualidade no atendimento.

Palavras-chaves: Excelência em atendimento. Motivação. Clima Organizacional. 


\begin{abstract}
The present work has as study object the relationship between the Organizational Climate and the quality of the service in Quality Resort Lakeside and in Metropolitan Flat, both administered by the Atlantic Net Hotels. The main focus of the research is the satisfaction characters with the work, incidents on the organizational climate in the work atmosphere. He breaks of the presupposition that the index of the customer's of the researched hotels satisfaction is related directly with the quality of the organizational climate. It is believed that the very willing employee and motivated for the work influences the organizational climate of the company positively and, in that way, it determines the quality of the accomplished services and the productivity as well as the quality so much of the service to the customer. The study accomplishes an incursion in the concept of the Organizational Climate looking for to understand that practice and their respective characteristics. He interprets the theoretical-methodological contributions become pregnant by the main authors that look for to understand the Organizational Climate in his origin and in their practical aspects. The study identifies and it evidences, for quantitative means, based in bibliographical research and evaluation of the organizational climate of Quality Resort Lakeside and Metropolitan Flat, some specificities of that practice, as for instance, their main concepts, the objectives of that discipline and his effectiveness in the practical application of their beginnings. In that sense, a research was accomplished with 34 employees of the hotel Lakeside and with 24 employees of the Hotel Metropolitan, in positions and functions varied, in the intention of setting out the most elementary variables and, like this, to identify to what extent the organizational climate has been influencing the quality of the service in the researched hotels. Therefore, a questionnaire of evaluation of the organizational climate was applied and the results demonstrated satisfactory level of organizational climate in the two researched hotels, suggesting influence of the organizational climate on the quality in the service. The research, therefore, he revealed that the organizational climate of Lakeside and of Metropolitan he is due, above all, to the benefits offered to the collaborators, to the trainings and incentive programs, as well as a politics of human resources gone back to the collaborators' satisfaction in the work atmosphere. Starting from those actions, the motivated collaborators and satisfied interact in a satisfactory way with the customers of the hotels, influencing the perception of the guests positively in relation to the quality in the service.
\end{abstract}

Word-key: Excellency in service. Motivation. Organizational climate. 


\section{LISTA DE FIGURAS}

Figura 1: Principais conceitos em Marketing. ..................................................... 65 


\section{LISTA DE QUADROS}

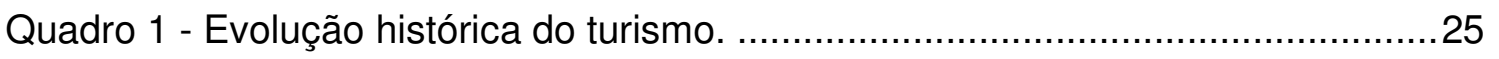

Quadro 2 - Caracteres de identificação de satisfação no trabalho ..........................86 


\section{LISTA DE GRÁFICOS}

Gráfico 1 - Satisfação do cliente por categoria de serviços / Lakeside..................104

Gráfico 2 - Satisfação do cliente por categoria de serviços / Metropolitan. .............104

Gráfico 3 - Satisfação do cliente em interação com colaboradores Lakeside..........105

Gráfico 4 - Satisfação do cliente em interação com colaboradores Metropolitan. ..105

Gráfico 5 - Satisfação dos clientes em situações que não exigem interação direta com o cliente Lakeside ....................................................................... 106

Gráfico 6 - Satisfação dos clientes em situações que não exigem interação direta com o cliente Metropolitan. 106 


\section{LISTA DE TABELAS}

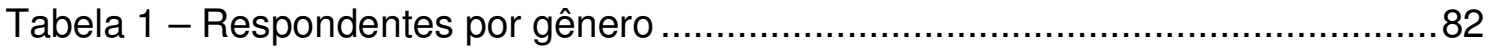

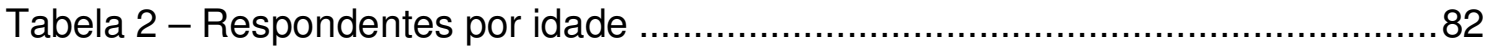

Tabela 3 - Respondentes por tempo de serviço .................................................... 83

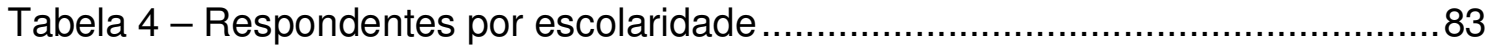

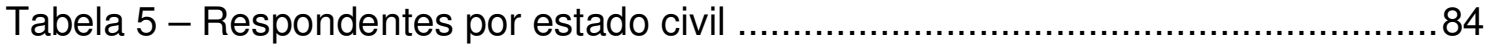

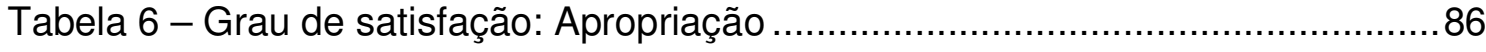

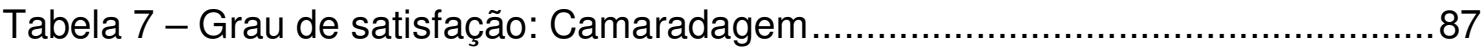

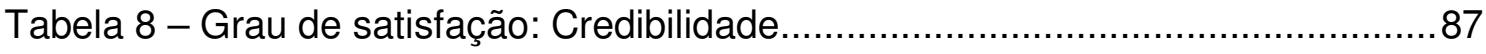

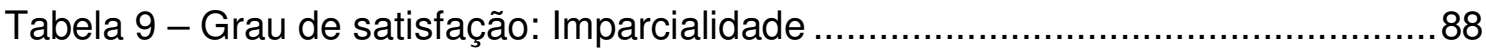

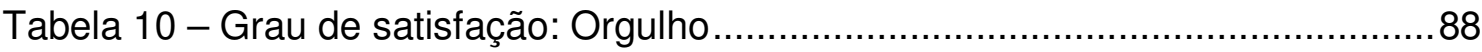

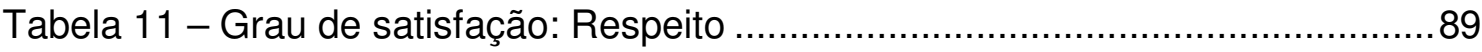

Tabela 12 - Indicadores de clima organizacional nos dois hotéis .............................90

Tabela 13 - Indicadores de satisfação do cliente.....................................................

Tabela 14 - Indicadores de satisfação do cliente em itens que não exigem interação direta com o cliente ..................................................................................

Tabela 15 - Indicadores de satisfação do cliente em itens que exigem interação direta com o cliente ....................................................................................... 


\section{SUMÁRIO}

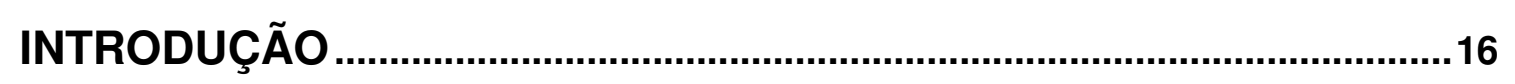

1 TURISMO: HISTÓRICO E FUNDAMENTOS........................................20

1.1 História do Turismo: Conceitos ..............................................................20

1.2 Evolução histórica do turismo …………………...............................24

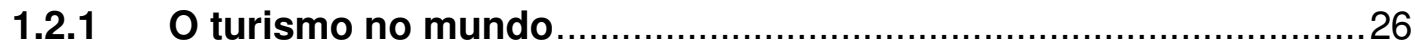

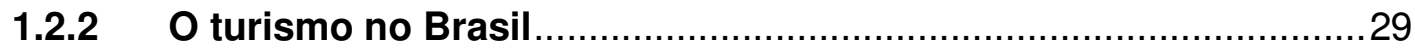

2 O MERCADO DA HOSPITALIDADE NO BRASIL .................................

2.1 Origens e conceitos do termo hospitalidade ..............................................35

2.2 O histórico da hotelaria no mundo ……………....................................36

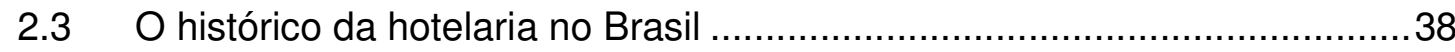

2.4 A força do mercado....................................................................... 41

3 GESTÃO ESTRATÉGICA: CLIMA ORGANIZACIONAL E

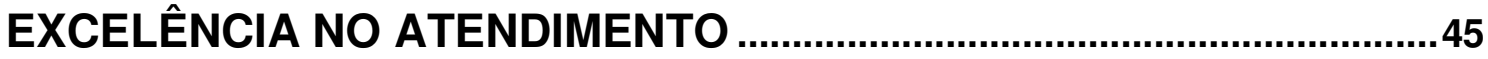

3.1 Origem, conceitos e relações entre clima organizacional e qualidade do

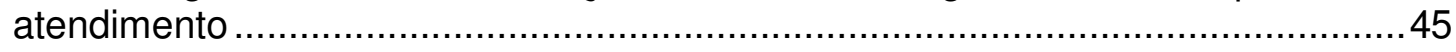

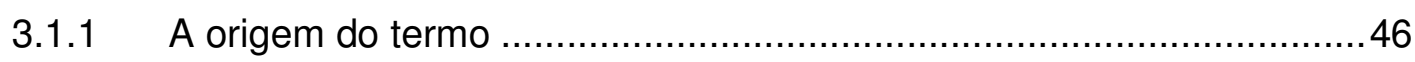

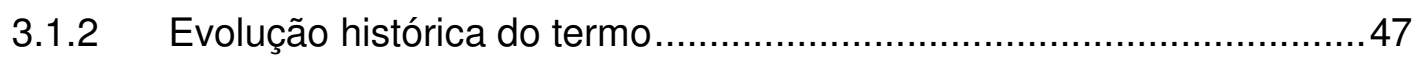

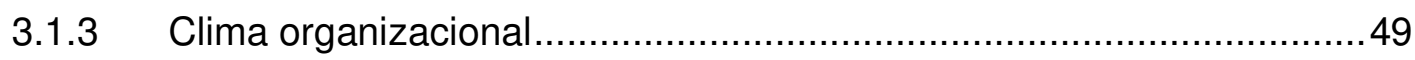

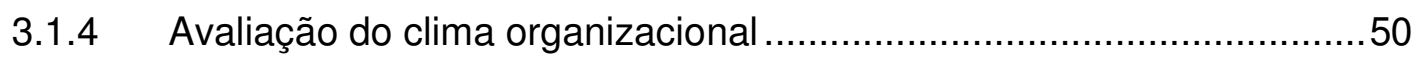

3.1.5 Requisitos para propiciar o melhor clima organizacional ....................61

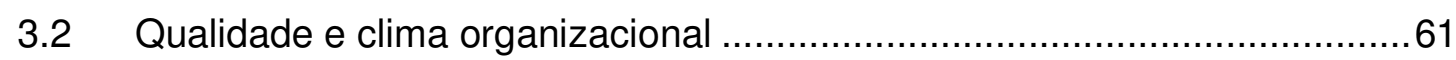

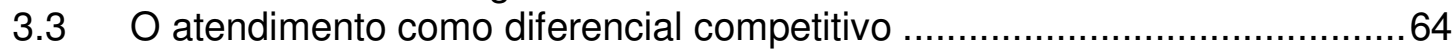

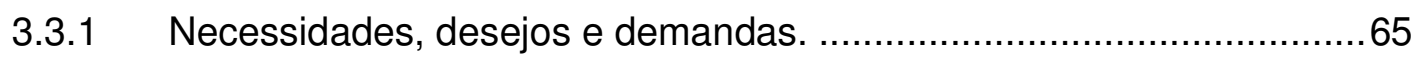

3.4 A motivação como fator importante em gestão de pessoas.........................70

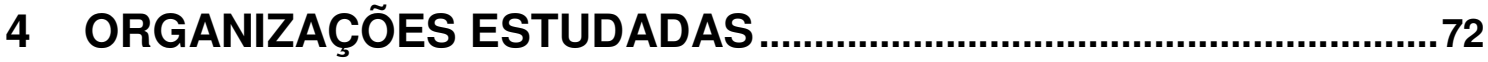

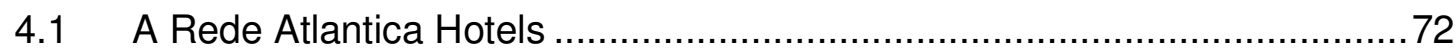

4.2 Caracterização do Quality Resort Lakeside ...............................................75

4.3 Caracterização do Metropolitan Flat ......................................................76

5 METODOLOGIA

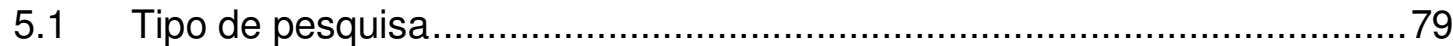

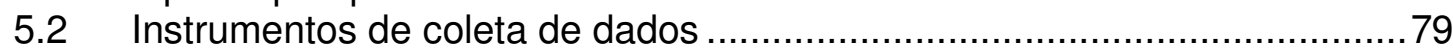

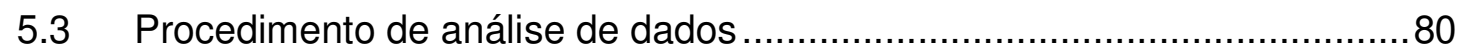

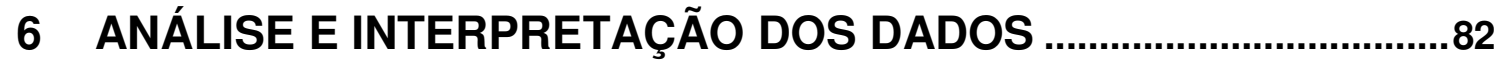

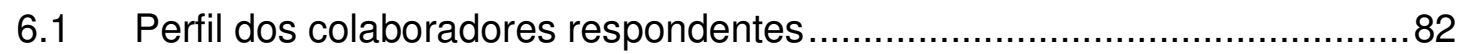

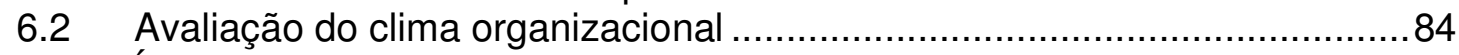

6.3 Índice de satisfação dos clientes .......................................................... 90

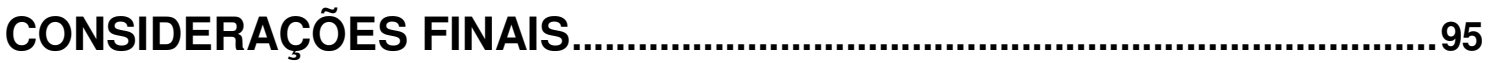


ANEXO I Questionário de Avaliação de Clima Organizacional Quality Resort Lakeside e Metropolitan Flat. 101

ANEXO II Gráfico de satisfação dos clientes Lakeside e Metropolitan Flat 104 


\section{INTRODUÇÃO}

O tema do presente trabalho é A Relação Entre Clima Organizacional e Excelência no Atendimento verificado empiricamente em dois hotéis de Brasília-DF: - Quality Resort Lakeside e o Metropolitan Flat, cujo objetivo geral foi analisar a relação da qualidade do clima organizacional e a qualidade do atendimento oferecido pelos colaboradores.

Ao realizar a pesquisa sobre relação entre o clima organizacional e a qualidade de seu atendimento em ambos os hotéis, buscou-se contemplar alguns aspectos importantes, por meio dos seguintes objetivos específicos: a) Pesquisar os autores da área; b) Descrever os serviços e a infra-estrutura dos hotéis estudados; c) Desenvolver pesquisa de campo relativa a clima organizacional e a satisfação no atendimento, D) Correlacionar a teoria da área com a prática das organizações pesquisadas.

Contudo, foram pesquisados os fatores de motivação e desmotivação no ambiente de trabalho que cooperam para a composição da satisfação pessoal dos funcionários tanto com o ambiente e condições de trabalho quanto com relação à equipe que o integra, pois o problema que se pretende pesquisar é: Qual a relação entre clima organizacional e qualidade no atendimento?

Se o bom atendimento é um dos requisitos de sucesso das empresas modernas, e atender bem envolve uma disposição pessoal de quem atende, então o clima organizacional se constitui fator importante, haja vista afetar diretamente a disposição das pessoas em um ambiente de trabalho. Portanto, parece haver uma relação positiva entre o clima organizacional e a disposição dos colaboradores na satisfação dos clientes. Dessa forma, se deduz que quanto melhor for o clima organizacional de uma empresa, melhor será a disposição de seus colaboradores e isso refletirá na satisfação do cliente, em função da qualidade do atendimento recebido.

Como o segmento da economia enfocado no presente trabalho é o turismo, mais especificamente o mercado de hotelaria, buscou-se fazer um embasamento teórico sobre a história do turismo, bem como sua evolução no mundo e no Brasil, pois foi a partir da demanda gerada nesse segmento que surgiu o conceito de hospitalidade, partindo da receptividade familiar para os variados tipos de 
hospedagens e, então, suscitando melhor desempenho na qualidade do atendimento.

Para conhecer as teorias dos principais autores sobre atendimento ao cliente optou-se pela realização de pesquisa bibliográfica, facilitando a compreensão da correlação entre clima organizacional e excelência no atendimento. Dessa forma, a pesquisa bibliográfica foi associada à avaliação do clima organizacional dos hotéis Quality Resort Lakeside e Metropolitan Flat, além da pesquisa documental sobre os índices de satisfação dos clientes nas duas empresas. Os dados coletados foram comparados no intuito de verificar a procedência da influência do clima organizacional sobre a qualidade do atendimento, conforme teoria pesquisada.

Para proceder à avaliação do clima organizacional nas duas empresas, foi elaborado um questionário contendo 34 afirmativas positivas, com cinco opções de respostas: 1) Discordo totalmente; 2) discordo parcialmente; 3) indiferente; 4) Concordo parcialmente; e 5) Concordo totalmente. O modelo de questionário elaborado segue os princípios utilizados pela empresa de consultoria Great Place to Work Institute, por ser esse modelo um dos mais utilizados no Brasil para pesquisa de avaliação de clima organizacional, inclusive para subsidiar a publicação das 100 melhores empresas para se trabalhar, veiculada por revista de grande circulação no país. O modelo criado por Livering reúne variáveis de outros cinco modelos, destacados no referencial teórico. Em seguida, comparou-se os resultados do clima organizacional de cada hotel, aferidos na pesquisa, com os respectivos índices de satisfação do cliente, com base em registros de avaliação realizado por cada uma das empresas.

Nesse sentido, para a realização do presente trabalho, abordou-se no primeiro capítulo os conceitos sobre turismo e agentes econômicos, sua evolução histórica, o mercado turístico e os efeitos da globalização, pois com a acirrada concorrência, as empresas precisam não apenas melhores produtos, mas também prestar o melhor atendimento possível. Com base nesse princípio, o presente estudo faz uma incursão teórica sobre o mercado de hospitalidade para compreender suas raízes históricas, bem como seus principais conceitos.

O segundo capítulo trata da origem e os conceitos do termo hospitalidade, pois entende-se que essa é uma das características mais marcantes no setor de hotelaria e que compõem os princípios do bom atendimento no segmento de 
turismo. Portanto, para se empreender melhorias na qualidade do atendimento como diferencial competitivo, se fez necessário observar certos aspectos do clima organizacional como recurso da gestão estratégica.

Para tanto, no terceiro capítulo foram abordados os princípios da Gestão Estratégica com foco na excelência no atendimento, utilizando-se dos principais conceitos de endomarketing, disciplina que trata do "cliente interno" e suas relações no ambiente do trabalho, cujas variáveis determinam a qualidade da vivência no ambiente de trabalho, conhecida por clima organizacional, bem como o impacto desse fenômeno sobre a qualidade do atendimento. Nesse mesmo capítulo, foram destacados os principais conceitos sobre clima organizacional e a relação que alguns autores fazem com a qualidade do atendimento e sua aplicação enquanto diferencial competitivo.

O quarto capítulo descreveu as organizações estudadas: Quality Resort Lakeside e Metropolitan Flat, por meio de suas respectivas caracterizações. $\mathrm{Na}$ seqüência, é feita uma comparação entre o clima organizacional e o índice de satisfação dos clientes dos hotéis pesquisados, cuja finalidade é apenas analisar o real impacto do clima organizacional sobre a qualidade do atendimento.

O quinto capítulo descreve a metodologia utilizada e o sexto capítulo faz uma análise e interpretação dos dados coletados.

Abordar o clima organizacional como fator de qualidade no atendimento, especificamente em atividades que exijam níveis elevados de qualidade, como é o caso dos serviços oferecidos pela Rede Hoteleira Atlantica Hotels International (Rede que tutela a bandeira "Quality"), pode trazer à tona soluções simples para questões elementares, que nem sempre são percebidas pelo grupo ou mesmo pelos gestores. De posse dessas informações, a elaboração de um plano de Gestão Empreendedora pode ser um passo significante para toda a força de trabalho que compõe a Rede.

Consciente dos benefícios dessa laboriosa e gratificante tarefa resta fazer uma breve reflexão sobre o desafio maior deste trabalho, que foi a observância do atendimento em seu aspecto qualitativo tanto na realização dos serviços quanto na relação com o cliente dos hotéis pesquisados. Tão importante quanto manter a produtividade, para atender um número cada vez maior de clientes em um espaço 
de tempo cada vez menor, é zelar pela qualidade desse atendimento, pois a revisão literária especializada tem demonstrado que a qualidade do atendimento é o fator de maior importância quando o assunto é conquistar e manter clientes.

Nesse aspecto, o segmento de hotelaria deve preocupar-se duas vezes com a qualidade do atendimento, pois não se pode conceber em qualquer empresa - que dependa de seus clientes para realizar suas metas financeiras - a hipótese de não atender bem seus clientes, quanto mais em um hotel com serviços para um público seleto e exigente.

Diante das demandas em relação à qualidade no atendimento é preciso conhecer a percepção e opinião de cada pessoa envolvida com as atividades da empresa para, só então, traçar um plano de ação rumo às condições idealizadas. Neste processo, considerou-se que a avaliação do clima organizacional é o método mais indicado e adequado para colher, analisar e avaliar as informações sobre as condições reais dos membros da equipe, e assim proceder à comparação com as expectativas de seus clientes e efetivar as ações necessárias para adequar às condições de trabalho ideais e que, imagina-se, jamais serão fixas e imutáveis, pois a cada alteração do grupo, quer seja em quantidade ou em qualidade, novas expectativas surgem e trazem consigo novas demandas que exigirão dos empreendedores e gestores, novos e diferentes tipos de avaliações e tomadas de decisões.

A importância da pesquisa da relação entre o clima organizacional e a qualidade do atendimento do hotel Lakeside e Metropolitan Flat se justifica pelo fato de que muitas informações importantes, às vezes, despercebidas pelos gestores, ou mesmo informações novas, possam ser buscadas e trazidas à apreciação e discussão das partes interessadas, promovendo a melhoria qualitativa na produtividade e no atendimento, incentivando a adoção de medidas de recursos humanos diversificadas, com vistas à promoção do bem-estar das pessoas que trabalham nos hotéis e, conseqüentemente, com influência positiva na qualidade final dos serviços prestados. 


\title{
1 TURISMO: HISTÓRICO E FUNDAMENTOS
}

\author{
1.1 História do Turismo: Conceitos
}

Para Ferreira (1993, p.553), Turismo significa "viagem ou excursão, feita por prazer, a locais que despertam interesse".

De acordo com Andrade (2000, p.9) "turismo é fenômeno social anterior às viagens que os jovens aristrocatas ingleses faziam, acompanhados de seus competentes e ilustrados preceptores".

Segundo Padilla (1997, p.33), o turismo é um fenômeno social caracterizado pelo deslocamento "voluntário e temporário de indivíduos ou grupos de pessoas". Dentre as várias motivações para esse deslocamento o autor cita "recreação, descanso, cultura ou saúde", entre outras atividades em que as pessoas deixam suas residências e se dirigem a outros locais para promoverem múltiplas interrelações de cunho social, econômico ou cultural.

A ênfase sócio-cultural dada por Padilla ao Turismo é atualmente adotada também pela Organização Mundial do Turismo, pois tal atividade possibilita a geração de benefícios para todos os envolvidos.

Contudo, Ruschmann (1997, p.13) afirma que a palavra turismo é relativamente recente e surgiu no século XIX. No entanto, as práticas de turismo remontam às mais antigas civilizações. Após a segunda guerra mundial, a evolução da prática do turismo se deu com maior velocidade, determinando novas metodologias de estudo e novas práticas como conseqüência dos aspectos relacionados à produtividade empresarial, e também impulsionados pelo poder de compra das pessoas e ao bem-estar resultante do restabelecimento da ordem e da tranqüilidade relativa no mundo, ocasionados pelo cessar guerra.

Até recentemente, a participação no turismo estava restrita a uma elite que dispunha de tempo e de dinheiro para realizar suas viagens. Atualmente, a maioria das pessoas dos países desenvolvidos, e um número significativo daquelas dos países em desenvolvimento, têm realizado viagens turísticas uma ou várias vezes ao ano (RUSCHMANN, 1997, p.13).

Se o turismo era vantagem de uma elite privilegiada, a popularização de suas atividades tornou-se acessível à grande maioria das pessoas, e constitui-se 
atualmente parte integrante do estilo de vida das pessoas, pois se apresenta sob as mais variadas formas.

Com o advento da industrialização e a expansão dos grandes centros urbanos, as condições de vida urbana têm perdido qualidade e esse fator, por si só, deflagra uma demanda considerável na busca da população por momentos de lazer e descontração durante as férias, feriados prolongados e até mesmo nos fins de semana.

Segundo Sauer (1975, apud RUSCHMANN, 1997, p.14) outros fatores contribuíram para o crescimento no setor, entre eles o autor destaca:

- o aumento do tempo livre como conseqüência da racionalização e do aumento da produtividade nas empresas. A jornada de trabalho - diária, semanal e anual - diminuiu, aumentando o tempo livre para atividades de lazer e turismo;

- a evolução técnica, que conduziu a um aumento na produtividade e à redução dos custos da produção. A produção em massa de veículos aumentou o grau de movimentação das pessoas, que se utilizam cada vez mais dos automóveis para viajar em férias;

- o aumento na renda de amplas camadas da população contribuiu para que parcelas crescentes dos rendimentos fossem direcionadas para os gastos com viagens e turismo;

- o desenvolvimento de empresas prestadoras de serviços que organizam e comercializam viagens de férias;

- a liberação das formalidades aduaneiras, a eliminação de vistos, a unificação de documentos de viagem, entre outros fatores, estimularam as viagens internacionais;

- o aumento da urbanização como conseqüência da industrialização; e,

- a falta das características do campo, nos grandes centros urbanos, incentivam as viagens de férias e de fim de semana.

As facilidades inerentes ao mundo moderno potencializaram a demanda por atividades turísticas e abriu espaço para que, cada vez mais, pessoas pudessem conhecer novas regiões, novas cidades, novos países e até o mundo todo, por meio 
de viagens emocionantes quer seja em outros grandes centros urbanos ou em regiões com recursos naturais e diferentes culturas.

Ruschmann (1997, p.15) explica que os anos de 1950 a 1970 foram marcados pela "[...] massificação da atividade; quando os vôos charters e os 'pacotes turísticos' conduziram milhares de pessoas às partes mais remotas do planeta, além de conduzi-las a localidades nos próprios países emissores".

[...] Sabe-se que a competitividade e a rentabilidade das empresas turísticas estarão baseadas na economia de escala, nos sistemas de lucro, na segmentação dos mercados e na finalidade dos clientes. Além disso, o turismo impessoal e de massa deverá ceder lugar ao high tech. (RUSCHMANN, 1997, p.17).

A autora (op. Cit) descreve que nos países desenvolvidos, o valor socioeconômico das atividades turísticas já se consolidou e, com o passar dos anos, se caracterizou como "o direito ao lazer".

Um detalhe importante entre conceituação de turismo e aquilo que se considera como prática turística exige um entendimento mais flexível do que sugere alguns autores.

De acordo com Lage (1991, p.25) algumas idéias podem definir o que seria turismo, entre essas idéias o autor destaca:

- para muitos especialistas, turismo são as viagens para regiões que distam mais de 50 milhas dos locais de residência;

- outros especialistas, ao conceituar turismo, exigem que os viajantes permaneçam mais de 24 horas nos locais visitados;

- algumas definições mais tradicionais incluem somente viagens de férias e de outras motivações como, por exemplo: de estudo, de eventos, de esportes, de saúde, de religião, de compras, de visitas a amigos e parentes. Algumas dessas definições incluem as viagens de negócio como uma variação de turismo. Mas qualquer que seja o motivo da viagem, sob o aspecto econômico, é importante ressaltar que o indivíduo que viaja para um país ou região não venha exercer, nessa localidade, uma ocupação remunerada; 
Mathieson e Wal (apud Lage, 1991, p.25) definem o turismo como:

- o movimento temporário de pessoas para locais de destinos externos aos seus lugares de trabalho e de moradia;

- as atividades exercidas durante a permanência desses viajantes nos locais de destino; e,

- as facilidades criadas para prover suas necessidades.

Embora sejam vários os conceitos e características que especificam e distinguem o Turismo, sabe-se que tal atividade assume importante papel na sociedade. O Turismo é uma das áreas promissoras quanto à estruturação da economia brasileira e, desde que foi descoberto, vem assumindo cada vez mais destaque no mercado globalizado.

A globalização possibilitou a expansão do turismo que se tornou fenômeno social, proporcionando a inter-relação entre várias classes e possibilitando a um número cada vez maior de pessoas conhecer outros povos, outras culturas em qualquer lugar do planeta, quer seja por meio de caminhadas ou qualquer meio de transporte disponível. O objetivo de tanta versatilidade é oferecer ao cidadão moderno a satisfação de suas necessidades, quer elas sejam de ordem acadêmica, financeira, social ou simplesmente lazer.

Para Andrade (1999, p.38), portanto, o Turismo é o conjunto de atividades para diversos fins e interesses que envolvem desde a assessoria para a escolha de um roteiro, deslocamentos, transportes, acomodações, alimentação, comercialização de produtos regionais, além das atividades relacionadas aos movimentos culturais, diversão e lazer.

Contudo, a Organização Mundial do Turismo - OMT (2007, p. 38), tem uma definição mais atualizada para Turismo, sendo:

todas as atividades que os indivíduos realizam durante suas viagens e permanência nos lugares fora de costume, por um período consecutivo inferior a um ano, com finalidade de lazer, negócios ou outras. 


\subsection{Evolução histórica do turismo}

Segundo a OMT (2007), a história do Turismo teve inicio quando o sedentarismo do homem deu lugar às suas viagens, em especial, motivadas pelas relações comerciais entre os povos. Nesse aspecto, compreende-se que o turismo de negócios é antecessor do turismo de lazer, embora este último caracterize melhor o significado genérico de turismo.

Para Beni (1997, p. 382), turismo de negócios pode ser caracterizado pelo "deslocamento de executivos e homens de negócios, portanto turistas potenciais, que afluem aos grandes centros empresariais e cosmopolitas a fim de efetuarem transações e atividades profissionais, comerciais e industriais".

De acordo com Ruschmann (1997, p. 22), o Turismo nasceu no Século XIX como atração, cuja finalidade principal é o lazer, descanso, cultura, saúde, negócios ou relações familiares. Estas atrações se diferenciam por sua intenção dos outros tipos de viagens motivadas por guerras, movimentos migratórios, conquista, comércio e outros. Mesmo assim o turismo tem uma história bem definida.

Conforme assevera Menezes (2007), foi a partir 1945 que o turismo ganhou novo espaço na economia mundial e determinou o seu futuro na sociedade. Antes dessa época, hotéis, operadores de transporte, agências de viagens e as agências de turismo trabalhavam de forma individual e não integrada. Visto antigamente como alguém que precisava apenas de acomodação, o turista despertou a atenção dos empresários do setor para outras necessidades.

Nessa perspectiva, as grandes redes de hotéis começaram a oferecer outros serviços, produtos e passaram a disponibilizar na sua estrutura física, lojas, spas, clínicas de estética, salão de beleza, entre outros, no intuito de oferecer mais comodidade e conforto ao turista, além de ampliar o tempo de permanência de seus clientes que, conseqüentemente geravam mais receitas para a empresa.

Menezes (2007) leciona que os conhecidos pacotes turísticos tiveram seu início na década de 80 , inclusive com o incremento da locação de veículos. Além de facilitar a visita do turista a outras regiões, os pacotes turísticos integram os mais variados tipos de serviço, possibilitando a redução de custos e, assim viabilizando a utilização por um maior contingente de pessoas de outras camadas sociais, além 
das classes ditas privilegiadas economicamente.

Molina (1994, p. 40) apresenta uma síntese da evolução turística, objetivando um panorama mais abrangente. Ele classifica a evolução turística em três grandes fases: Pré-turismo, Turismo Industrial e Pós-turismo, descritos no quadro a seguir:

\begin{tabular}{|c|c|}
\hline \multicolumn{2}{|c|}{ Evolução histórica do Turismo } \\
\hline Pré-turismo & $\begin{array}{l}\text { Corrente no século XVII na Europa, onde os filhos dos } \\
\text { comerciantes ricos viajavam para lugares de elevado nível } \\
\text { cultural e comercial. }\end{array}$ \\
\hline Turismo & $\begin{array}{l}\text { O Turismo Industrial Inicial - ocorrente no século XIX } \\
\text { até o início da segunda Guerra Mundial com o surgimento dos } \\
\text { grandes hotéis; } \\
\text { O Turismo Industrial Maduro - a grande explosão a } \\
\text { partir dos anos } 60 \text { e fundamentada no sistema "operadora- } \\
\text { avião-hotel-praia"; } \\
\text { O Turismo Pós-industrial - que surge a partir dos anos } \\
80 \text { e é baseado na diferenciação dos produtos/serviços e } \\
\text { também na desmassificação dos mercados, atendimento } \\
\text { personalizado e o ecoturismo que deriva as estratégias de } \\
\text { crescimento sustentável. }\end{array}$ \\
\hline Pós-turismo & $\begin{array}{l}\text { O deslocamento se torna desnecessário, podendo-se } \\
\text { realizar turismo na própria cidade aonde se vive, recorrendo à } \\
\text { mega-hotéis que têm por características: um nulo contato com } \\
\text { indivíduos das comunidades locais; contato com cenários } \\
\text { naturais adaptados, aplicando a alta tecnologia; substituição da } \\
\text { mão-de-obra pela tecnologia, e, não se produz coma os } \\
\text { recursos naturais ou culturais da região. }\end{array}$ \\
\hline
\end{tabular}

Quadro 1 - Evolução histórica do turismo.

Fonte: MOLINA, Sérgio. El Pós Turismo: de los centros turísticos industriales a las ludópolis. México: MOLINA, 1998. p 98.

É interessante observar que não necessariamente uma etapa substitui a 
outra. Ocorre que as mudanças são tão rápidas que pode-se perceber a interação entre as fases destacadas por Molina. A verdade é que a evolução do turismo acontece de forma gradual e constante, não havendo portanto uma mudança abrupta e repentina como insinua a síntese no quadro 2.

Ruschmann (1997, p. 113) se refere a evolução do Turismo como:

[...] um processo de transformação no qual a exploração de recursos, a direção dos investimentos, a orientação da evolução tecnológica e mudança institucional se harmonizam e reforçam o potencial presente e futuro, a fim de atender às necessidades e aspirações humanas (Ruschmann, 1997, p.113).

\subsubsection{O turismo no mundo}

Levando em consideração as idéias de Padilla (1997), Ruschmann (1997), Beni (1997) e OMT (2007) onde afirmam que o turismo é definido como atividade social, econômica e cultural, cuja finalidade é a integração dos povos para fins de vivências e trocas de experiências entre as pessoas e, portanto, uma atividade globalizada por excelência, o turismo representa uma das principais atividades sócio-econômicas mundiais, com força de trabalho equivalente a 10,7\% da mão de obra em todo o planeta, ou seja, um em cada 10 trabalhadores no mundo prestam serviços no segmento de turismo, demonstrando assim, o poder desse segmento na geração de renda e emprego.

Para Lage (1991, p. 7), nos últimos anos, a importância do turismo vem crescendo significativamente no mundo, cujas empresas do ramo vêem apresentando os maiores índices de viabilidade econômica em relação a outros setores como a indústria automobilística, por exemplo.

Coriolano (1998, p.9) reforça a idéia de Lage (1991) quando assevera que:

[...] a importância e o significado do turismo no mundo tem crescido de forma tão expressiva que vem dando a esta atividade lugar de destaque na política geoeconômica e na organização espacial, vislumbrando-se como uma das atividades mais promissoras para o futuro milênio.

De modo geral, a população mundial parece estar inserida em um mesmo contexto de desenvolvimento tecnológico e modernização de porcessos, cuja dinâmica é invarialvelmente estressante e desgastante, não importando a 
nacionalidade das pessoas envolvidas nessa dinâmica. Portanto, é natural que as pessoas procurem cada vez mais atividades que lhe proporcionem melhoria na qualidade de vida. Dessa forma, o turismo deixa de ser considerado luxo de pessoas privilegiadas e passa a ser uma necessidade de todas as pessoas que precisam, de alguma forma, melhorar sua qualidade de vida.

Conforme Castelli (2001), o turismo tem proporcionado aos indivíduos não apenas o contato com outras civilizações, culturas e costumes, mas principalmente a quebra da rotina, por meio de divertimento e momentos de descanso ao tempo em que a pessoa também pode conhecer lugares novos. Nesse sentido, a internet tem cooperado significativamente, pois tem possibilitado aos futuros viajantes a oportunidade de ver o local de destino sem mesmo sair de casa, dando origem a um novo tipo de cliente, mais exigente e com maior quantidade de informações.

De acordo com Hazin (2001) a era da informação tem oportunizado encurtar as distâncias. Esse fenômeno tem suas vantagens e desvantagens. Como o dia a dia está sendo transformado gradativamente pelas engenhosidades modernas na área de comunicação, um novo perfil de cliente surge, determinando mudanças em todos os setores da atividade comercial.

Por meio da internet e da TV, as pessoas recebem notícias instantâneas do mundo todo e ficam a par do que ocorre em todo o planeta, em tempo real. As barreiras de comunicação em todo o globo terrestre foram derrubadas e o acesso às informações se tornou tão fácil quanto clicar um mouse. Esse fator possibilita a interação com quase todos os tipos de pessoas espalhadas pelo mundo. A tecnologia proporcionou às pessoas a oportunidade de "viajarem" sem sair de casa. O intercâmbio por meio das tecnologias disponíveis tem estabelecido trocas de experiências e informações que, ao longo do tempo, transformarão a vida das pessoas de modo geral.

A televisão foi, talvez, um dos primeiros instrumentos de globalização, pois mostrava ao cidadão comum continentes, países e cidades que jamais poderia conhecer não fosse por meio de um passeio virtual, devido a dispendiosidade do programa. Canais de televisão especializados, fornecem dados completos sobre os principais pontos turísticos no mundo todo.

Atualmente, assim como a TV, a internet tem oferecido oportunidades 
interativas para se conhecer lugares em qualquer parte do planeta. No entanto, a vantagem da internet sobre a televisão é que a internet possibilita ao usuário escolher o lugar e selecionar as informações que mais lhe interessa.

Se por um lado o passeio virtual pode "trazer" lugares até as pessoas, por outro essa degustação turística suscita a vontade de conhecer o lugar assistido ou pesquisado. Isso tem aflorado nas pessoas o interesse por conhecer lugares diferentes.

A idéia de viajar vem penetrando de tal forma na mente do homem moderno que, cada vez mais, se fortalece como uma conquista, um direito, uma possibilidade, um consumo. Pode-se afirmar que a viagem é hoje um dos grandes consumos criados no contexto da sociedade através dos meios de propagação coletiva, sobretudo os meios de comunicação de massa eletrônicos (CORIOLANO, 1998, p.30).

Acredita-se que a influência da globalização na rotina das pessoas irá promover importantes alterações no ser humano impulsionando-os a adotar a viagem como alternativa de lazer. O princípio do capitalismo, associado a essa transformação mundial, tem popularizado e facilitado o turismo.

A necessidade imperiosa de viajar é fabricada, sendo incorporada mercadologicamente ao rol das necessidades básicas do homem. É o homem urbano que constitui o chamado Homo turísticus ou Homo viajor (Rodrigues, 1997: 26).

Para Hazin (2000, p1) "[...] o início da movimentação turística coincide com o desenvolvimento da sociedade industrial, mas o surgimento de um 'turismo de massas' ou um 'turismo moderno' foi observado a partir da década de cinqüenta"

Beni (1998, p.37) leciona que antes da revolução industrial a sociedade demonstrava preocupação com os aspectos da mundialização do turismo e, em 1937, a Comissão Estatística da Liga das Nações previa a definição do conceito de turista internacional toda "pessoa que visita um país que não seja o de sua residência por um período de, pelo menos, vinte e quatro horas".

Entretanto, Trigo (1998, p. 65) assevera que, com a aceleração do processo de globalização, o segmento de turismo tem superado todas as expectativas e previsões estatísticas, apresentando desenvolvimento extraordinário, com movimentação de recursos da ordem de centenas de milhares de dólares a cada 
ano. Para o autor, "a atividade turística passou a ser um espaço privilegiado da produção, na medida em que se tornou uma das ocupações sofisticadas do setor terciário".

\begin{abstract}
Muitos fatores contribuíram, nos países ocidentais, para o crescimento do que alguns insistem em identificar como "a indústria sem chaminé" (Lago, 1996:63; Lemos, 1999:207). Além da estabilidade política de muitos países, do crescimento econômico (com a formação das classes médias), da melhoria das condições de vida de uma parcela da população (com a redução das horas de trabalho), dos avanços tecnológicos (com o transporte mais rápido e a comunicação facilitada), o acesso `a cultura e à educação por um maior número de pessoas despertou o interesse em conhecer outras manifestações culturais, outros lugares (HAZIN, 2001).
\end{abstract}

É notório o impulso econômico que a globalização oportunizou ao turismo, tornando-se um fenômeno mundial. A Organização Mundial de Turismo registrou, só em 1980, um volume de US $\$ 105,3$ bilhões e, em 1997, registrou a cifra de US\$ 443,8 bilhões para o movimento decorrente dessa atividade em todo o planeta (GALINDO apud GUIMARÃES, 1999, p. 5).

Hazin (2001) afirma que no ano de 1991, segundo essa mesma organização, "o setor ocupava 101 milhões de pessoas e os investimentos alocados correspondiam a $7 \%$ dos investimentos mundiais".

Segundo Carvalho (1994, p. 2) o produto bruto estimado para 2003 no segmento de Turismo foi de US\$ 8 trilhões, "com investimentos no setor estimado em US\$1,7 trilhão e devendo empregar, segundo essa projeção, 350 milhões de pessoas que gerarão na atividade US\$ 1,5 trilhão em impostos".

Para Molina (1994), apesar dos aspectos econômicos serem exorbitantes, eles não são os únicos a beneficiarem o setor. $O$ autor destaca ainda o aspecto da "[...] comunicação entre as pessoas que viajam ou, até mesmo, o contato direto com a natureza e a cultura do lugar visitado. Essa experiência permite ao homem contemporâneo uma alternativa de 'ser-ter' uma outra realidade".

\title{
1.2.2 O turismo no Brasil
}

Trigo (1998, p.113) afirma que, em termos de Turismo, o Brasil "dorme em berço esplêndido". Segundo o autor, no ano de 1990 "entraram 1,08 milhão de 
turistas estrangeiros no país e o Rio de Janeiro teve uma queda de 397,9mil para 257,7 mil, de 1989 para 1990, devido à precariedade da estrutura urbana e à farta propaganda sobre a violência".

Soares (2000, p.81) considerou "ridículo" o Brasil ocupar o 29ำ lugar no ranking da OMT, ficando atrás de países como a Argentina, Malásia, Hungria e Irlanda.

Sicoli (2005, p.1) também comentou a esse respeito no ano de 2005:

\begin{abstract}
O Brasil ocupa o 26이 lugar no ranking da Organização Mundial de Turismo, apesar de ter uma variedade impressionante de atrativos: belezas naturais, cachoeiras, praias, florestas, cidades históricas, cidades modernas, centros industriais, um rico calendário de festas e eventos, culinária diversificada, festivais de música e arte, eventos esportivos, ritmos musicais diversos, que poderia em pouco tempo nos alavancar para as primeiras posições do ranking. A população bastante miscigenada, com várias cores, sotaques e origens étnicas, chama bastante atenção dos visitantes, pois apesar de toda as diferenças, convive alegremente e pacificamente com diversas vertentes religiosas,étnicas e culturais, e unida por uma só língua falada em todo seu território, o português.
\end{abstract}

De acordo com notícia da BBC Brasil, publicada em 19/12/2006 pelo CET/UnB, o Brasil saiu da lista dos 10 destinos preferidos pelos europeus e passou do $2^{\circ}$ para o $14^{\circ}$ entre a lista dos "próximos destinos". Uma das causas citadas pelo responsável pela edição do Guia atribui à distância e às constantes notícias de violência divulgadas pela mídia internacional.

Riqueza natural exuberante, povo hospitaleiro, cultura diversificada e uma produção musical reconhecida mundialmente fazem do Brasil um pólo turístico excepcional, entretanto o país "não está preparado para a invasão provocada pelo turismo de massas. E, apesar do despreparo, ele virá" (Santos, 1997, p.5).

Santos (1997) afirma que "a globalização favorece a divulgação das belezas das nossas matas, praias e grutas que vão sendo 'descobertas' pelos viajantes alternativos". Para o autor, são esses atrativos que abrem caminho para uma exploração desregrada, indisciplinada e devastadora.

Para Santos (1997, p.5) "o Brasil não decidiu entrar na globalização, apenas deixou entrar a globalização, é de se esperar que a produção da desordem se acelere, gerando pobreza, desemprego, desigualdade". 
Nessa perspectiva, o Instituto Brasileiro do Turismo - EMBRATUR, implementou e ampliou ações diversificadas para tratar desses problemas e, principalmente, em decorrência do aumento da importância do turismo na economia nacional.

\begin{abstract}
Caio Luiz de Carvalho, presidente da Embratur, em discurso realizado no Seminário sobre competitividade do turismo e luta contra a pobreza, realizado em Natal-RN, em junho de 2001, realça a necessidade de reverter as condições sócio-econômicas do país através do turismo, enfatizando que esse setor tem a capacidade de transformar "tradições, manifestações espontâneas da música, da dança e da cultura de um povo, transformar suas montanhas, florestas, desertos, rios e praias em riqueza". Tal afirmação torna, ainda mais urgente, a elaboração de medidas que visem a preservação da identidade cultural, já que constitui um diferencial de peso na escolha do destino de uma parcela significativa de visitantes (HAZIN, 2001, p.1).
\end{abstract}

Hazin (2001) leciona que as políticas de marketing mais agressivas têm vendido o "Nordeste turístico, tanto dentro do Brasil como em outros países, vêm trazendo resultados visíveis no incremento do número de visitantes à região". Por essas razões, a autora ressalta a "necessidade urgente de monitoramento científico do fenômeno, uma vez que o turismo justapõe culturas e identidades, ressalta diferenças".

Com o objetivo de intensificar o uso turístico de seus territórios, os governos dos estados da federação, com o aval do poder público federal, vem implementando duas políticas regionais para a atividade: uma voltada para os grandes projetos e a outra, mais diversificada, procura injetar recursos nas áreas com comprovado potencial turístico (HAZIN, 2001, p.1).

Entretanto, para Cruz (2000, p.131)

[...] não basta a aplicação dos recursos gerados a partir desses dois programas. Para que se obtenham os resultados esperados, é necessário que ocorra uma articulação em rede, das diversas políticas ligadas à atividade turística, inclusive "nas respectivas capitais dos estados, lugares estratégicos para o processo de expansão territorial do turismo, como nós de uma rede mundialmente organizada".

Já Coriolano (1998, p.18) ressalta que o preparo na participação desse processo de intensificação turística no Brasil "[...] implica não apenas modernizar, produzir e competir, mas encontrar os meios para distribuição de renda, dando 
prioridade ao homem".

Nessa perspectiva, percebe-se a importância de atenção à população hospedeira que participa diretamente na acolhida ao visitante. É preciso valorizar e preparar os moradores da região que se pretende atrair turistas, pois sem o preparo adequado, a questão da hospitalidade pode se tornar um elemento negativo ao invés de funcionar como atrativo.

Robinson (1999, p.22) leciona que:

"O conflito entre turista e anfitrião talvez seja o mais evidente. Ele nasce em parte de uma divergência radical de objetivo: o primeiro entrega-se a uma atividade de prazer, o segundo trabalha. O turista chega com muitas expectativas; os anfitriões, com muita freqüência, não têm a menor idéia do que devem esperar dele"

Castelli (2001, p.36) assevera que "Embora o progresso tecnológico tenha trazido inovações e aperfeiçoamentos no seio das empresas hoteleiras, o elemento humano continua sendo a peça fundamental".

Dentre todas as atividades econômicas praticadas no Brasil, o turismo tem se destacado de forma especial. Em vários países os governos despertaram para os benefícios econômicos encontrados na prática do turismo, pois o potencial de geração de emprego e renda é muito elevado e tem sido constatado de forma significativa, a ponto de receber atenção especial por parte de políticos, empresários entres outros grupos de interesse (LEMOS, 1999, p.9).

Devido à demanda crescente pelas atividades turísticas, esse segmento da economia está entre as quatro principais atividades econômicas do mundo, conforme afirma Lemos (1999, p.10):

[...] de fato, este setor está entre as quatro principais atividades econômicas do mundo. Gera empregos em grande quantidade e receitas gigantescas para os países que optam por essa alternativa de crescimento. Soma-se o fato da probabilidade de que seja a principal atividade econômica do mundo na virada do milênio.

Segundo Lemos (1999, p.19) As ciências econômicas estudam dois importantes campos: a microeconomia e a macroeconomia, onde define a primeira como sendo o campo responsável por estudar o comportamento individual dos 
agentes econômicos, tais como: consumidores e empresas; e a segunda como sendo a compreensão mais ampla dos sistemas econômicos, como por exemplo: a renda nacional, o nível de emprego e dos preços, bem como as circunstâncias em que o governo pode operar para intervir ou influenciar essas variáveis.

De acordo com Lage (1991, p.30), os agentes econômicos mais importantes são os consumidores e as empresas, sendo que os consumidores buscam o melhor de seus interesses pessoais e as empresas buscam multiprodução de bens e serviços, visando melhores lucros.

Dentre as muitas ofertas e procura por bens e serviços econômicos, uma que se destaca é o serviço de turismo, que tem como alvo satisfazer a necessidade de lazer das pessoas, bem como vários grupos que fazem parte e interagem, fazendo o turismo existir e crescer como um todo, conforme exemplifica Lage (Op.Cit):

- os turistas: têm como objetivo suprir necessidades psíquicas e físicas, fazendo o melhor de suas viagens o que fará as escolhas do destino, transporte, hospedagem e o que fazer de lazer.

- as empresas turísticas: visando melhores lucros, buscam multi produção de bens e serviços, conforme a demanda do mercado turístico.

- o governo: recebem o turismo como aumento da economia que é motivado pela receita e arrecadação dos impostos gerados pelo mercado de turismo.

- a comunidade anfitriã: formada pelas pessoas nativas da região turística que têm o turismo como cultura. Para eles o mais importante sendo o resultado das interrelações entre os residentes e os visitantes.

Sendo que o mais importante motivo para o crescimento do turismo é a interação de alvos e trabalhos dos quatro grupos de agentes que fazem parte dessas atividades turísticas. 
Uma outra importante segmentação do setor econômico é a divisão por setores. Lemos (1999, p.23) destaca essa segmentação dos setores da economia como:

- Setor primário: que envolve agricultura, a pecuária, a pesca, a extração de minérios e de vegetais, a horticultura e outros;

- Setor secundário: que engloba as empresas industriais, por exemplo: máquinas e equipamentos, automóveis, autopeças, plásticos, móveis, construção civil, alimentos industrializados, tecidos e diversos outros; e,

- Setor terciário: que envolve atividades de serviços como: educação, transporte, comunicação, saúde, bancos, lazer e entretenimento, serviços de hospedagem, eventos, fornecimento de energia, água, esgoto e outras.

As atividades de turismo, portanto, pertencem ao setor terciário, pois envolvem a prestação de serviços por meio de empresas e agências. Destarte, pode-se perceber a influência do turismo nas atividades dos outros dois setores, uma vez que demanda uma série de consumo dos chamados bens intermediários.

Bahl (Org, 2004, p.3) informa que, segundo a Embratur, já em 1994 o Brasil havia recebido 1,7 milhões de turistas estrangeiros e, em 2000, em apenas 6 anos, esse número havia triplicado, tendo evoluído para 5,3 milhões. No mesmo ano, foram registrados 38,2 milhões de turistas domésticos, tendo movimentado US $\$ 25,8$ bilhões na economia interna brasileira, somente no ano de 2000.

Com base nas perspectivas anunciadas à respeito do turismo de modo geral, percebe-se um campo crescente e cada vez mais promissor para o mercado de hospitalidade, pois quanto maior for o número de pessoas se deslocando de suas casas para conhecer ou visitar novos lugares, maior será a demanda por modalidades de hospedagem, fomentando ainda mais o mercado de hotelaria em todo o mundo.

A tendência de crescimento do setor de serviços em hospitalidade coloca a indústria hoteleira como uma das principais atividades de geração de renda e emprego, além de ser considerada uma indústria ecologicamente correta, demonstrando o quanto este setor pode contribuir com a sociedade de modo geral. 


\title{
2 O MERCADO DA HOSPITALIDADE NO BRASIL
}

\author{
2.1 Origens e conceitos do termo hospitalidade
}

A hospitalidade, de modo geral, é um costume de origem familiar que se estendeu para a área comercial, tomando proporções industriais como é o caso das grandes redes hoteleiras. Entretanto, as características peculiares da hospitalidade requerem muito mais do que simplesmente oferecer e cobrar por um espaço onde a pessoa possa descansar e fazer sua higiene.

De acordo com Dias (2002, p.13) as atividades de hospitalidade abordam:

[...] desde a satisfação de necessidade de ordem psicológica, passando pelas trocas culturais, até as relações socioeconômicas, chegando à discussão sobre os aspectos atuais da indústria da hospitalidade e serviços de alimentação.

Portanto, percebe-se que a hospitalidade não se limita aos serviços oferecidos pelos hotéis, mas indica a participação de toda a população de uma determinada localidade, pois desde a chegada ao aeroporto ou a rodoviária, o turista entra em contato com diversas pessoas que trabalham em setores da cadeia turística. Nesse aspecto, a hospitalidade começa no desembarque, continua no hotel e termina na partida do cliente. O resultado sobre a qualidade da hospitalidade dependerá da leitura que o turista fizer durante sua permanência na localidade visitada, estando além das limítrofes da hotelaria.

De acordo com Castro (2004, p.1) "a hospitalidade tem sido estudada por vários pesquisadores do mundo inteiro. Com isso, existem diferentes tendências em sua análise" e aponta algumas linhas de pensamento no meio acadêmico mundial.

O estudo francês possui uma tendência sobre a hospitalidade pública, já o estudo americano aborda a hospitalidade comercial, para nós brasileiros seria o equivalente ao estudo da hotelaria [...] e tem a pretensão de identificar uma análise ampla da hospitalidade, abordando todos os espaços da hospitalidade, inclusive a hospitalidade comercial onde existem análises sobre o que percebemos "além dos contratos mercantis" sob a forma de doação incondicional e que podemos nos remeter ao estudo da "dádiva", discutido por Jacques Godbout (1999) em o "espírito da dádiva" (CASTRO, 2001, p.1). 
De acordo com Watanabe (2007) "a hospitalidade é um conceito tão antigo quanto às formas mais remotas de atividade social, desde as mais arcaicas, tanto no Ocidente como no Oriente; considerada como um atributo de pessoas e de espaços".

Segundo Ferreira (1993, p.290) hospitalidade se refere à hospedagem e é a qualidade de quem é hospitaleiro. Para hospitaleiro, Aurélio define como aquele "que dá hospedagem por bondade ou caridade; ou que acolhe com satisfação (hóspedes)".

A origem desta palavra vem do latim e que tem significado de acolhimento. Nesse sentido, hospitalidade indica a atribuição de valor ao tratamento dispensado às pessoas.

Atualmente, estudiosos de administração de serviços relacionam a hospitalidade como valor e princípio para ser cultivado pelas empresas. O objetivo é antecipar-se às necessidades dos clientes nessa era onde o cliente é o foco principal.

\subsection{O histórico da hotelaria no mundo}

A análise e o entendimento do mercado da hospitalidade no mundo, significa abordar a conhecer conceitos de receptividade turística, atendimento, presteza, encantamento, gastronomia e uma arrojada gestão de pessoas.

De acordo com Campos (2003, p.11), com a chegada do século XX, o segmento da hotelaria ganhou um novo rumo, com direção, organização e padronização, ganhando assim, importância semelhante à adotada pela indústria tradicional da época.

Segundo Lattin, (1998 apud CAMPOS, 2003, p.12) entre 1750 e 1820, a Nova Inglaterra, diversificou conceitos, inovou e melhorou serviços, conquistando assim, a reputação de serem os melhores hospedeiros da época, ainda com pequenas e medias estruturas.

A cidade de Nova York, em 1794, oficializa a abertura de seu primeiro projeto especialmente construído para ser um hotel: o City Hotel, com 73 quartos. 
Essa estrutura tornou-se uma referencia empresarial e social para os nova-iorquinos bem-sucedidos. O City Hotel foi o primeiro grande passo para a evolução da hotelaria nos Estados Unidos. (LATTIN 1998).

Conforme Campos, (2003) o segmento da hotelaria nos Estados Unidos foi marcada por três grandes movimentos:

- Na metade do século XIX, com a construção de prédios próprios para hotéis nas grandes cidades do Leste, que possuíam camas para duas ou três pessoas, chaves na porta e bacia com jarro de água para higiene simples.

- No mesmo período, quando a corrida para o Oeste propiciou não somente a expansão das ferrovias, como também a instalação de hotéis nas cidades em desenvolvimento do Meio-Oeste em direção ao Pacifico. Esses hotéis ofereciam ainda, refeições e banho. Outros agregavam também o jogo e a prostituição, resultando nas primeiros hotéis-cassinos de Oeste.

- Entre 1930 e 1940, com a expansão da industria automobilística e da malha viária americana, surgiram os primeiros motéis, sendo que em 1963, os Estados Unidos já contabilizavam 36 mil motéis à beira das rodovias.

Abbey (1989 apud CAMPOS, 2003) afirma que no começo dos anos 50, a hotelaria mundial, principalmente a americana, evoluiu em função de diversos fatores, onde entre eles, os principais foram:

- Crescimento populacional;

- Maior longevidade da população;

- Aumento da renda familiar;

- Crescimento do tempo destinado ao lazer;

- Expansão das grandes rodovias;

- Desenvolvimentos das zonas suburbanas;

- Crescimento das viagens aéreas.

Percebe-se uma evolução histórica e estrutural da hotelaria mundial. O crescimento populacional, a evolução cultural e as necessidades naturais do ser humano foram fundamentais para a afirmação da hotelaria. 


\subsection{0 histórico da hotelaria no Brasil}

Para Campos (2003, p.11), "a grande dificuldade de conhecer e analisar o mercado da hospitalidade no Brasil decorre do fato de que os serviços hoteleiros em nosso país foram tratados [...] como um negócio agregado à família".

Outro aspecto sobre as origens da hospitalidade brasileira, diz respeito às instituições religiosas como é o caso do Colégio de Jesus de Salvador, que possuía em sua estrutura uma casa de hóspedes, cujo objetivo era hospedar pessoas recomendadas por autoridades, às vezes pagantes ou até mesmo por questões de caridade (CAMPOS, 2003, p.15).

Com a demanda crescente de negócios, cultura e recreação no Brasil do século $\mathrm{XIX}$, as estruturas de hospedaria tiveram que se adaptarem para receber os visitantes. Dessa forma, houve um processo de massificação do turismo, exigindo, entre outras coisas, a evolução dos meios de transportes para tornar as viagens mais acessíveis às classes menos abastadas financeiramente, possibilitando que mais pessoas usufruíssem dos serviços nesse setor, conforme afirma Badaró (2007).

Segundo a Confederação Nacional do Comércio (2007, p. 21), no Brasil, "Os hotéis de melhor categoria começaram a surgir em antigas mansões, como o Hotel Ravot [...] ou fora do centro do Rio, alguns deles em bairros afastados". Além de oferecerem maior conforto aos seus hóspedes, as suntuosas e espaçosas mansões preservavam seus hóspedes dos inconvenientes de qualquer grande centro urbano, como barulho, o movimento contínuo e a ausência de infra-estrutura de saneamento na capital daquela época. Outro atrativo eram as belas paisagens, peculiares ao campo.

De acordo com Caldeira (1995, apud CAMPOS, 2003, p. 16) em meados do século XIV, havia no Rio de Janeiro duas centenas de estabelecimentos de hospedagem, em sua maioria de propriedade estrangeira e apenas um terço empreendido por brasileiros. No entanto, em termos de hotelaria, "o grande marco foi o Hotel Avenida, inaugurado em 1908 com 220 quartos e salas tidas como magníficas". 
Belchior e Poyares (1987, p. 40) relatam que o desenvolvimento hoteleiro no Brasil, a partir da Capital Federal, na época o Rio de Janeiro, incentivou o comércio e a utilização de muitas novidades tecnológicas, além de inserir o hotel na vida social colaborando para a transformação dos costumes próprios da sociedade colonial, a exemplo das festas e exposições artísticas promovidas pela Corte portuguesa, promovendo inclusive shows com artistas internacionais, fomentando a taxa de ocupação nos hotéis da cidade. Desde então os hotéis passaram a fazer parte do roteiro de diversões da cidade, promovendo bailes e festas de carnaval, oferecendo um ambiente alternativo e mais requintado para os foliões mais elitizados que queriam se divertir sem os inconvenientes das ruas.

Dados da Confederação Nacional do Comércio (2005, p. 24) revelam que o turismo seguiu crescendo em outras regiões do país, a partir da segunda metade do século XIX, a exemplo do Rio Grande do Sul, onde a cidade de Porto Alegre passou a contar, em 1870, com o Hotel del Siglo, localizado na Praça da Alfândega. Também no Estado de Minas Gerais, foi inaugurado em 1881 o Hotel Caxambu e o Grand Hotel Pocinhos, instalado na Cidade de Poços de Caldas. Tais hotéis se constituem os mais antigos ainda em funcionamento no Brasil.

Os hotéis eram procurados, sobretudo, por imigrantes, conforme relata a Confederação Nacional do Comércio (2005, p. 24):

\begin{abstract}
Nessa época, nada foi mais impactante para o turismo no Brasil do que a imigração, não apenas pela exigência de acomodações para os imigrantes, mas também pela experiência que traziam nos serviços de hotelaria europeu. No Rio Grande do Sul, por exemplo, de 1859 a 1875, o Governo da Província registrou o número de 12.563 estrangeiros, das seguintes nacionalidades: alemães (8.412), austríacos (1.452), italianos (729), franceses (648), suíços (263) e outros (105).
\end{abstract}

Com a revolução industrial e a necessidade de mão de obra qualificada e experiente nos ramos que se expandiam no Brasil, inclusive o ramo hoteleiro, muitas empresas contratava mão de obra estrangeira e com isso o número de imigrantes que chegavam ao Brasil não parava de crescer (BADARÓ, 2007).

A Confederação Nacional do Comércio (2005, p. 26) confirma o relato de Badaró (2007), ao registrar que "[...] em apenas cinco anos, de 1895 a 1900, a população da paulicéia saltou de 130 mil habitantes para 240 mil. Enquanto isso, a atividade hoteleira crescia incessantemente na cidade". 
Segundo Campos (2003, p. 17), "o crescimento da rede hoteleira no Brasil está ligado ao desenvolvimento das formações urbanas do começo do século $\mathrm{XX}$ atrelado aos caminhos das ferrovias". Nesse sentido, as regiões mais desenvolvidas, a exemplo da Região Sudeste, foram mais beneficiadas pela cultura cafeeira e a abertura das grandes fazendas.

Com as demandas da produção rural para os grandes centros urbanos, o fluxo de pessoas era intenso entre essas localidades, aumentando consideravelmente a oferta hoteleira.

Além da área produtiva e comercial, as atividades de lazer e entretenimento também mantinham suas demandas em alta escala. Entretanto, com a proibição do jogo no governo de Eurico Gaspar Dutra, em 1946, os hotéis que mantinham suas taxas de ocupação em função do jogo, quase vão à bancarrota e precisaram investir em atividades alternativas como as fontes termais, por exemplo, muito difundido para cura de diversas doenças orgânicas (CAMPOS, 2003).

Com a entrada da indústria farmacêutica no Brasil, oferecendo medicamentos para cura e controle das doenças que eram objeto do termalismo, mais uma vez os hotéis se vêem desafiados a sobreviverem a uma baixa taxa de ocupação, afetando inclusive os hotéis urbanos.

Com a decadência das grandes redes hoteleiras da época, os investimentos migraram para o setor imobiliário. Dessa forma, hotéis eram demolidos e davam lugares a edifícios com salas comerciais ou residenciais (CONFEDERAÇÃO NACIONAL DO COMÉRCIO, 2005).

Com a construção da nova Capital Federal, passa a prevalecer o governo militar que privilegiaria a modernização dos transportes e a expansão das comunicações. Com isso, houve um surto desenvolvimentalista, promovendo a indústria automobilística, ao tempo em que sucateavam a malha ferroviária, enfraquecendo ainda mais três setores de negócios: as ferrovias, os hotéis e os cinemas. 


\subsection{A força do mercado}

Segundo a Confederação Nacional do Comércio (2005), com a crise no segmento de turismo por efeito da proibição dos cassinos no País e da decadência da hotelaria por conta dos prejuízos que se abatia sobre esse setor da economia, surgiu a união de representantes de agências de viagens e criaram, em 1953, a ABAV - Associação Brasileira das Agências de Viagens.

Não obstante as mudanças políticas do fim do século XIX terem feito sucumbir os investimentos turísticos e, em especial, o setor hoteleiro no Brasil, o turismo tem se mostrado como um dos segmentos da economia que oferecem a melhor relação custo benefício.

Para Wille (2007, p.1) o mercado de turismo "[...] é uma das atividades econômicas mais promissoras para o novo milênio". Segundo a autora, essa afirmativa é muito mais do que uma simples afirmação otimista à respeito do segmento, ao afirmar:

\footnotetext{
Empreendedores nacionais e estrangeiros, os diversos setores da economia que estão envolvidos com a área de Eventos, Lazer e Turismo, as entidades representativas (EMBRATUR, ABAV, $A B I H$, etc.), além das instituições governamentais, já perceberam essa realidade. Da mesma forma, perceberam também, que muitas ações podem e devem ser feitas para melhorar o mercado do Turismo no Brasil.
}

De acordo com números do IBGE (2007), o Brasil recebeu em 2001 cerca de 4.773 milhões de estrangeiros, sendo que $28 \%$ dessas pessoas foram para o Rio de Janeiro.

Segundo dados da Associação Brasileira de Viagens, atualmente o turismo movimenta, no mundo, aproximadamente $\bigcup \$ 3,5$ trilhões, representando quase $10 \%$ do PIB da terra. A Embratur informa que a indústria do turismo no Brasil movimenta mais de $\mathrm{R} \$ 30$ bilhões, o que representa algo em torno de $3,5 \%$ do PIB nacional, sendo que o turismo interno responde por, aproximadamente, $80 \%$ deste total. (REVISTA TURISMO, 2007).

Para justificar esse crescimento, Martin (2003, p.183) cita a "[...] estabilidade monetária do real, a queda da taxas de juros, o crescimento da economia brasileira e a modernização da infra-estrutura como formas fundamentais para estimular a vinda 
de capital estrangeiro".

Para Martin (2003, p.183), a vantagem em se investir no turismo é devido ao fato do turismo requerer baixo investimento, se comparado a outros setores da economia, fato que também contribui muito para o crescimento acelerado no setor. Ela exemplifica a facilidade de geração de emprego e faz uma comparação entre a indústria do turismo e a indústria automobilística dizendo que: "[...] bastam $\mathrm{R} \$ 10.000$ para gerar um emprego em restaurante e $R \$ 40.000$ para a mesma vaga em hotel. Na indústria automobilística, são necessários R\$170.000".

Apesar de o turismo mostrar toda essa potencialidade, por meio de números expressivos, seu desenvolvimento depende de outros fatores como, por exemplo, a conscientização da responsabilidade de todos, em promover ações sociais e envolver a comunidade nos aspectos de preservação do meio ambiente e dos recursos naturais, bem como o setor empresarial destinar recursos para investimentos nas comunidades receptoras dos turistas, com vista a otimizar o receptivo turístico.

Neste sentido, Martin (2003, p.183) informa a necessidade em se conhecer os componentes do turismo e a dinâmica entre esses elementos para poder potencializar a procura por um determinado destino turístico.

Por destino turístico Martin (2003, p.184) considera alguns elementos importantes, tais como:

- Atrativos: Museus, galerias, locais históricos, parques e jardins, parques de diversões, cultura local, indústria e agro-turismo, artesanato, boates, clubes e instituições;

- Aventura e divertimento: Parques, pesca esportiva, esportes e aventuras, náutica e esportes ao ar livre;

- Alimentação: Restaurantes, refeições, café, comida típica, bares e serviços de abastecimento;

- Comércio de viagens: Agência de viagens e operadoras de turismo;

- Eventos: Eventos especiais, encontros, conferências, convenções, festivais, mostras comerciais, feiras e exposições;

- Hospedagem: Hotéis, motéis, estâncias, campings, pensões, quartos, hotéis de lazer, lodges, hotéisresidência, flats, albergues e pousadas; 
- Serviços turísticos: Departamentos turísticos oficiais, centros de informação, serviço de reserva, guias de turismo, associações profissionais, consultores, educadores de turismo, serviços básicos e segurança; e,

- Transportes: Companhias aéreas, ônibus, ferrovias, marítimo e fluvial, locadoras de veículos, veículos recreativos, táxis, postos de gasolina e oficinas mecânicas.

Contudo, dados da OMT divulgados pelo Sebrae (2007) revelam que desde o atentado ao World Trade Center, em 2002, e também devido aos conflitos recentes entre países do Oriente Médio com envolvimento dos EUA, alguns lugares sofrem retração:

[...] no ano de 2003, foram realizadas no mundo 649 milhões de viagens, representando uma queda de $1,2 \%$ em relação a 2002, queda esta motivada pelos conflitos globais. Apesar dos números negativos, a América do Sul vem tendo aumentos significativos de procura, haja vista, ser uma região localizada fora das zonas de conflito. O Brasil é um dos países da América Latina que mais demonstram este crescimento, no ano de 2000, o país recebeu 5,3 milhões de turistas estrangeiros, atingindo um recorde histórico. Este índice ainda é pequeno se comparado aos apresentados por países como a França, Estados Unidos e Espanha e se levarmos em consideração a diversidade de atrativos que o país apresenta. Hoje, o Brasil possui infra-estrutura e projetos turísticos que atestam a sua vocação na área de uma forma mais concreta e consistente do que na última década.

Como visto, apesar de alguma retração no setor, o turismo não pára de crescer e tem recebido muitos investimentos em praticamente em todo o mundo e no Brasil esse fato é uma realidade, onde empresários e principalmente o governo brasileiro, demonstram interesse na geração de empregos e distribuição de renda, em especial no mercado de entretenimento e, por conseqüência, em hotelaria.

Campos (2003, p. 32) revela que apenas no mercado brasileiro de hotelaria se concentram cerca de um milhão de trabalhadores, que prestam serviços em pelo menos 19 mil meios de hospedagem. O faturamento no ramo de hotelaria, no país alcançou, em 2000, um volume de 10 bilhões de reais e 75 bilhões em atrativos fixos, conforme dados da Associação Brasileira da Industria de Hotéis - ABIH.

Segundo Stilpen (2007, p.1) a expansão do turismo, em especial do mercado de hotelaria no Brasil tem sido responsável pela geração de empregos diretos e indiretos em diversos setores da economia. Segundo o autor, o efeito 
multiplicador do turismo repercute em, pelo menos, 52 ramos de atividade. Esse fato por si só demonstra a força do mercado de turismo no Brasil.

Além da geração de emprego e renda, Stilpen (2007) destaca que a construção em ritmo acelerado de hotéis, resorts, pousadas, entre outras modalidades de hospedagem, em diversas localidades no Brasil, tem beneficiado a população local tanto do ponto de vista econômico quanto sócia. Dentre os efeitos deste setor, o autor destaca "[...] maior arrecadação de impostos, preservação do meio ambiente, conservação do patrimônio histórico, geração de empregos desestimulando, inclusive a migração".

Nesse sentido, o turismo tem se estabelecido cada vez mais como excelente fonte de rentabilidade para o Brasil, recebendo investimento de um número crescente de empresários e investidores em diversos segmentos do comércio e da indústria, inclusive na modalidade de franquias. 


\section{GESTÃO ESTRATÉGICA: CLIMA ORGANIZACIONAL E EXCELÊNCIA NO ATENDIMENTO}

3.1 Origem, conceitos e relações entre clima organizacional e qualidade do atendimento

Não se pode conceber a qualidade sem um agente motivador. Os trabalhadores têm seus objetivos e metas pessoais que estão condicionados e subordinados aos objetivos e metas profissionais. Dessa forma, as pessoas sabem que para alcançarem os objetivos pessoais precisam realizar antes suas tarefas profissionais de forma satisfatória.

Salgado (2005, p. 41) assevera que quando se fala em motivação, não se pode deixar de falar em liderança. Nesse sentido, Uma das teorias mais conhecidas para definir o comportamento individual e o modo de agir de cada pessoa ou grupo diante de determinada situação parte da investigação dos traços da personalidade.

Definida por Allport (1966, p. 50) como: "organização dinâmica no indivíduo dos sistemas psicofísicos que determinam seu comportamento e seu pensamento característicos" a personalidade se distingue, na opinião do autor, de caráter e personalidade. Para o autor, o caráter associa-se mais aos hábitos, atitudes e interesses apresentados pelo sujeito, enquanto temperamento está relacionado aos fenômenos de natureza emocional do indivíduo, incluindo a estimulação, intensidade e situações que predispõem a manifestação destes fenômenos.

A importância de se diferenciar personalidade, caráter e temperamento fazse fator necessário, pois muitas vezes tidos como semelhantes percebe-se que de fato tratam de características intrínsecas do ser humano, entretanto, a personalidade está muito mais ligada à essência do indivíduo, enquanto caráter e temperamento em algum momento relacionam-se com fatores externos.

Nos estudos sobre motivação, a teoria dos traços de personalidade mantém maior aceitação sobre os estudos acerca de caráter ou de temperamento. Uma das hipóteses que provavelmente envolve esta questão pode ser explicada devido ao fato de que líderes historicamente reconhecidos mantinham traços semelhantes em sua personalidade e tinham um fator motivacional bastante destacado. 
Evidentemente não se tem uma personalidade definida para esta ou aquela pessoa, mesmo porque é a combinação de diversos traços que irá delinear a personalidade de cada ser humano. Entretanto, segundo Stogdil (apud PIETRI JR, MOSLEY e MEGGINSON, 1998, p.379), teórico desta linha de pesquisa, as pessoas que mais se destacam no cumprimento de suas metas, apresentam um conjunto de traços encontrados em sua personalidade, não apenas no caráter ou temperamento.

Dentre os traços encontrados pelo pesquisador encontram-se: habilidade pessoal e interpessoal, habilidade técnica, habilidade administrativa e espírito de liderança eficaz, o que não significa dizer que a pessoa motivada nasça com gens de motivação.

\subsubsection{A origem do termo}

Semanticamente, o termo "Clima" foi emprestado da climatologia e aplicado em outras áreas do conhecimento por sua analogia em relação à "temperatura" de um determinado lugar. A palavra "clima" vem do grego "Klima", quer dizer inclinação, tendência; que na Climatologia refere-se à incidência dos raios solares sob um determinado lugar ou região, entre outras influências de fatores atmosféricos, a qual, determinam a diferença de temperatura e as estações em cada parte do planeta (BRESCANCINI, 2007).

Clima organizacional é semântica e analogamente definido por especialistas em lingüística como "a atmosfera do ambiente de trabalho", ou seja, as expectativas e percepções mantidas por colaboradores em relação a vários fatores profissionais, tais como: membros da equipe, condições de trabalho, plano de salário, plano de carreira, sentimento de realização e produtividade, entre outros, que determinam as características do ambiente profissional (BRESCANCINI, 2007).

O estudo sobre clima organizacional tem chamado a atenção de especialistas de diversas áreas, em especial da Administração, por meio da disciplina de Marketing/Endomarketing e da Psicologia, por meio da Psicologia Organizacional. 


\subsubsection{Evolução histórica do termo}

Levando em consideração o trabalho realizado por Forehand e Gillmer (1964), comparado com os estudos apresentados por James e Jones (1974), Palácios (2006) conclui que "[...] houve uma grande mudança na compreensão do clima organizacional, em relação à apresentada por Forehand e Gillmer (1964)".

Palácios, (2006) salienta que a mudança observada, diz respeito ao reconhecimento da dinâmica entre a organização e seus colaboradores, corrigindo o papel de "fornecedores de informação" para "[...] responsáveis pela construção do clima a partir do significado que outorgam àquilo que percebem".

Nesse sentido, James e Jones (1974 apud PALACIOS, 2006) influenciam com seus estudos a construção de uma nova visão sobre o clima organizacional, deslocando seu sentido com base em um fato isolado para reconstruí-lo a partir do significado global que o indivíduo atribui à organização.

Em 1983, Scheneider e Reichers (apud PALÁCIOS, 2006, p. 6) publicam artigo tratando da etiologia do termo clima organizacional, onde descrevem uma síntese das três abordagens identificadas:

a) a abordagem estrutural: essa abordagem é similar à abordagem de mensuração organizacional de atributos múltiplos apresentada por James e Jones (1974). Tal definição explica o surgimento do clima organizacional a partir de aspectos objetivos da organização como tamanho, centralidade ou descentralidade, número de níveis hierárquicos, tipo de tecnologia utilizada na produção e grau em que as políticas são obstáculos para o comportamento;

b) a abordagem da seleção via atrito-atração: está sustentada nas percepções individuais. A similaridade dessas percepções seria o resultado de um processo de seleção realizado tanto pela organização como pelos indivíduos que a ela se vinculam. Este processo de mútua escolha explicaria a relativa homogeneidade entre os membros da organização e, portanto, a similaridade das suas percepções sobre os aspectos organizacionais e sobre o clima; e,

c) a abordagem interativa: é denominada interacionismo simbólico e constitui uma nova proposta, realizada por Schneider e Reichers, para a compreensão da etiologia do clima organizacional. Tem como fundamento, segundo os autores, os 
trabalhos sobre o interacionismo simbólico, realizados por Mead em 1934.

Pode-se perceber que a mudança fundamental no conceito de clima organizacional, apresentada pelos autores citados, diz respeito à ênfase dada no aspecto social dos relacionamentos internos.

Para Palácios (2006) "[...] o clima deixa de ser concebido como um evento que ocorre dentro do indivíduo, para ser analisado à luz de uma perspectiva social". Portanto a definição do termo clima organizacional é relativo e variável, pois leva em consideração a percepção de um determinado grupo, com base nos significados atribuídos e sustentados socialmente pelos membros desse grupo aos eventos que ocorrem no meio organizacional.

Moran e Volkwein (1992 apud PALACIOS, 2006, p.8) definem em seus estudos (1992) os termos mais recentes sobre conceito de clima organizacional, bem como as suas diversas abordagens. Para eles a perspectiva sobre o termo diz respeito à forma de conceber o clima organizacional, com ênfase na abordagem cultural, onde afirmam:

[...] o clima organizacional é fortemente influenciado pela cultura da organização na qual os indivíduos estão inseridos. Esta abordagem está relacionada com a nova corrente teórica conhecida como paradigma interpretativo, segundo o qual os grupos nas organizações moldam o senso comum em relação à história, valores, intencionalidade e propósito das ações organizacionais, por meio da interpretação coletiva. A este respeito, os autores comentam que há uma mudança do foco psicológico primário inerente à abordagem interacionista, para um foco sociológico. O centro da análise deixa de ser o indivíduo que percebe e passa a ser o grupo de pessoas que "vive" a organização.

No entanto, Palácios (2006, p.8) reitera:

[...] A diferença fundamental entre a abordagem interativa e a apresentada por Moran e Volkwein (1992) radica na compreensão que padrões de comportamento não constituem somente reflexos de processos cognitivos aprendidos num processo de estímulo e resposta. Esses comportamentos, segundo os autores, estão sustentados na cultura da organização, a qual, por sua vez, está baseada em um sistema de significados compartilhados pelo grupo. Assim, a cultura não está presente apenas nos processos cognitivos de indivíduos, mas nos processos de interação que ocorrem entre indivíduos. 


\subsubsection{Clima organizacional}

Em Psicologia Organizacional, o Clima Organizacional é um tema estudado há pelo menos quatro décadas, no entanto, segundo Palácios (2006, p.1) "[...] a falta de clareza a respeito do seu significado e extensão continuam sendo uma constante".

Segundo a autora (op. Cit) Forehand e Gillmer foram os primeiros a organizarem as publicações existentes sobre o conceito de clima organizacional. Ambos estudaram, em 1964, 104 obras divulgadas entre os anos de 1939 e 1963 sobre o tema, onde concluem que clima e ambiente organizacional são considerados sinônimos. A partir daí, surgia então mais uma nova disciplina: a Psicologia Organizacional.

A ênfase de estudo dessa escola da Psicologia é o comportamento organizacional, cujos interesses científicos se referem "[...] aos impactos que mudanças ocorridas no seio das organizações, tinham sobre o clima" (PALACIOS, 2006).

Clima organizacional é definido como "a qualidade do envolvimento afetivo entre os membros de uma equipe, que buscam objetivos comuns" (ALVES, 2000, p.1).

Fourgous e Iturralde (1991, apud ALVES, 2000) entendem o fenômeno como:

[...] o conjunto de características objetivas e relativamente permanentes da organização, percebidas pelos indivíduos pertencentes à organização, que servem para the dar uma certa personalidade e que influenciam o comportamento e as atitudes de seus membros.

Forehand e Gillmer (1964) definem o clima organizacional como:

[...] o conjunto de características que descrevem uma organização e que: a) a distinguem de outras, b) são relativamente duradouras ao longo do tempo; e c) influenciam no comportamento das pessoas na organização. Em relação à mensuração do construto, afirmam, os problemas são semelhantes aos enfrentados por estudiosos do comportamento individual, pois a personalidade seria para o indivíduo o que o clima seria para a organização. A partir da revisão de literatura, identificaram, como metodologias de mensuração do clima, a observação intensiva em situação 
de campo, a avaliação das percepções dos membros sobre a organização, a observação de propriedades organizacionais objetivas e a manipulação experimental das propriedades organizacionais.

Por sua vez, Abbey \& Dickson (1983) lecionam que clima organizacional é "a qualidade de um ambiente interno de uma organização, que resulta do comportamento e conduta dos seus membros". Para os autores, a condição do clima no ambiente de trabalho serve como referência na interpretação das situações com impacto direto sobre as atividades, direcionando-as de forma positiva ou negativa.

Já Campbell et al. (1970, apud PALÁCIOS, 2006) asseveram que o clima organizacional pode ser visto como:

[...] um conjunto de atributos específicos de uma organização em particular, que pode ser influenciado pela forma como esta organização lida com seus membros e seu ambiente. Para cada indivíduo dentro da organização, o clima assume a forma de um conjunto de atitudes e expectativas estáticas (tal como o grau de autonomia), como variáveis comportamentais de resultado ou eventos de saída.

Em uma perspectiva filosófica, Luz (1996) diz que: "clima organizacional é o reflexo do estado de espírito ou do ânimo das pessoas, que predomina numa organização em um determinado período" e salienta a importância de se considerar o fator tempo na interpretação do conceito, pois o clima do ambiente interno de uma organização é instável e se modifica conforme a interferências de inúmeras variáveis.

Dessa forma, entende-se que clima organizacional é o resultado da percepção de uma realidade objetiva que os trabalhadores constroem de acordo com o que vivenciam e sentem em relação ao grupo em que trabalham e à organização de um modo geral, e que se modifica de forma dinâmica e constante em função de diversas variáveis.

\subsubsection{Avaliação do clima organizacional}

Posteriormente, com base nos princípios e conceitos citados, vários modelos de avaliação do clima organizacional foram surgindo. Dentre os principais, Pereira (2003, p.20-25) destaca os seguintes: 
a) Modelo de Litwin e Stringer

O modelo proposto por Litwin e Stringer (SANTOS apud PEREIRA, 2003) apresenta sete fatores:

Conflito: é o sentimento de que os membros da organização, em todos os níveis, aceitam opiniões contrárias e não temem enfrentar e solucionar problemas tão logo estes surjam

Cooperação: é o sentimento dos membros da organização sobre a existência de um espírito de ajuda tanto por parte das lideranças quanto dos demais colegas, dando ênfase no apoio mútuo;

Desafio: corresponde à percepção dos membros da organização quanto aos desafios impostos pelo trabalho;

Estrutura: representa a percepção dos membros da organização sobre a quantidade de regras, procedimentos e outras limitações enfrentadas para a realização dos trabalhos;

Recompensa: corresponde à percepção dos membros sobre a adequação da recompensa por um trabalho bem feito. Essa recompensa serve como reforço positivo sobre uma atitude ou sobre um resultado esperado do colaborador;

Relações: é a percepção dos membros da organização acerca da existência de um ambiente de trabalho gratificante e de boas relações sociais, tanto entre os pares quanto entre chefe e subordinados; $\mathrm{e}$,

Responsabilidade: é o sentimento dos membros da organização a respeito da sua autonomia nas decisões relacionadas ao seu trabalho. Leva em consideração se a supervisão que recebem é do tipo mais geral, ou seja, o sentimento de ser seu próprio chefe.

b) Modelo de Kolb

Conforme descreve Pereira (2003, p. 21) o modelo de Kolb (1986), apresenta a definição de oito fatores, tornado-o uma ampliação do modelo de Litwin e Stringer:

Clareza organizacional: percepção dos membros da organização de que os 
padrões e as rotinas de trabalho estão organizados, assim como as metas claramente definidas;

Conformismo: sentimento de que há muitas limitações impostas pela organização; com inúmeras regras, políticas e procedimentos. Determina que o indivíduo deve se amoldar e não fazer à sua maneira;

Padrões: é a percepção dos membros acerca da ênfase que a organização coloca nos padrões de desempenho e se esses são objetivos desafiadores;

Recompensa: mede o nível de reconhecimento por um trabalho bem feito. Este quesito está relacionado também com o nível de crítica e das punições;

Relações: sentimento de que as relações entre seus membros são positivas, que existe confiança entre eles;

Responsabilidade: grau com que os trabalhadores podem tomar decisões e resolver problemas sem consultar seus superiores em cada etapa;

Cooperação: existência de um espírito de ajuda mútua entre os membros da organização; e,

Liderança: a disposição dos membros da organização em aceitar a liderança e a direção de pessoas qualificadas.

\section{c) Modelo de Sbragia}

O modelo aplicado por Sbragia (1983), é constituído de um instrumento de coleta de dados privilegiando vinte fatores (PEREIRA, 2003, p. 22-23):

Adequação da Estrutura: descreve o quanto o esquema organizacional facilita as ações das pessoas, em termos de normas e canais de comunicação consistentes com os requisitos do trabalho;

Apoio logístico proporcionado: indica o quanto a organização provê às pessoas os recursos necessários para um desempenho adequado;

Atitude perante conflitos: descreve o grau com que as pessoas estão dispostas a considerar opiniões diferentes e a explicitar os conflitos existentes;

Autonomia presente: reflete o grau de liberdade que as pessoas têm para tomar decisões; 
Clareza percebida: descreve o quanto a organização informa seus membros sobre os assuntos relevantes para eles;

Condições de progresso: descreve o grau com que a organização disponibiliza oportunidades e estimula o crescimento profissional;

Conformidade exigida: grau de flexibilidade que os membros têm dentro do contexto organizacional;

Consideração humana: indica o grau de humanização com que a organização trata seus membros;

Cooperação existente: descreve o grau de confiança entre os membros da organização e o quão boa é a relação entre eles;

Ênfase na Participação: grau de envolvimento dos membros da organização no processo decisório e da aceitação de idéias e sugestões;

Estado de tensão: grau com que as pessoas agem e decidem de forma lógica e racional;

Forma de controle: descreve o grau com que a organização usa indicadores de performance para melhorias ao invés de usá-los para punições;

Justiça predominante: explicita o grau com que os critérios de habilidade e desempenho são considerados nas decisões da organização;

Padrões enfatizados: descreve a ênfase que é dada nas metas e os padrões de desempenho;

Prestígio obtido: indica a percepção dos membros da organização de como são vistos pelos agentes externos;

Proximidade da supervisão: indica como o controle é exercido pelo supervisor e qual o grau de autonomia que o empregado tem para definir os métodos de trabalho;

Recompensas proporcionais: descreve como as pessoas são recompensadas pelo trabalho e quão justas são a política de remuneração e os planos de carreira;

Reconhecimento proporcionado: descreve o quanto o desempenho diferenciado é valorizado e reconhecido pela organização; 
Sentimento de identidade: deixa claro sobre as pessoas sentirem que pertencem a organização; e,

Tolerância Existente: indica como os erros das pessoas são tratados pela organização.

\section{d) Modelo de Coda}

De acordo com Pereira (2003, p. 23-24) o modelo de Coda (1997) foi aplicado em diversas pesquisas de clima organizacional realizadas em empresas públicas e privadas no Brasil. Este modelo comporta dez fatores de análise:

Acesso: grau de acesso a outros tipos de trabalho ao longo da carreira;

Colaboração entre áreas funcionais: descreve o grau de respeito e colaboração entre as diversas áreas para atingir os objetivos da organização;

Compensação: descreve o equilíbrio do pacote de remuneração, ou seja, amplitude dos benefícios, relatividade com mercado, concessão de promoções por desempenho;

Identificação com a empresa: sentimento de pertencer a uma grande equipe em busca de objetivos mútuos;

Liderança: descreve o grau de feedback e orientação fornecido ao subordinado sobre seu desempenho;

Maturidade empresarial: compreensão dos membros da organização sobre o mercado, concorrentes e expectativa dos clientes; valorização de altos padrões de desempenho;

Política global de Recursos Humanos: apoio fornecido pelas políticas de $\mathrm{RH}$ e importância desta área;

Processo de comunicação: rapidez na comunicação de decisões, informações necessárias ao bom desempenho das pessoas são disponibilizadas de forma clara;

Sentido de Trabalho - importância do trabalho realizado para os objetivos da organização; e,

Valorização profissional: estímulo ao desenvolvimento e crescimento 
profissional; disponibilização de oportunidades de crescimento e promoção.

e) Modelo de Kozlowski

O modelo proposto por Kozlowski (1989), conforme pontua Pereira (2003, p. 24-25), destaca onze fatores relevantes para proceder à avaliação do clima organizacional conforme descrito a seguir:

Apropriação: indica como é percebido o grau com que o empregado é responsabilizado por suas ações;

Comunicação: é o grau de suficiência na comunicação em termos de receptividade, abertura e fluxo;

Cooperação: mede a percepção de que existe cooperação entre as diversas áreas da organização;

Ênfase de supervisão: indica como é percebida a pressão de trabalho feita pelo supervisor;

Entendimento do trabalho: indica se os objetivos das empresas estão bem claros para os membros da organização;

Estrutura do trabalho: indica como são percebidas a organização e a estrutura do trabalho;

Gerenciamento consciente: indica a percepção do grau em que os gerentes estão preocupados com as necessidades dos empregados;

Participação: indica o grau de incentivo por parte do supervisor em relação a participação dos empregados nos processos de decisão;

Responsabilidade: indica como é percebido o grau de autonomia para tomar decisões;

Suporte: indica como são percebidos o grau de apoio, confiança e respeito demonstrados pelo supervisor; e,

Trabalho em equipe - indica a percepção de que existe um ambiente de cooperação e amizade na equipe. 
f) Modelo The Great Place to Work Institute

Este último modelo destacado por Pereira (2003, p. 25-26) foi elaborado pelo escritório de consultoria americana GPTW-Great Place to Work Institute, desde1997.

Segundo Pereira (2003, p.25), a proposta desse modelo não é avaliar diretamente o clima organizacional, mas "[...] estabelecer um conjunto de fatores que permita a comparação do grau de satisfação dos empregados em diversas organizações empresariais".

Neste sentido, Pereira (2003, p.26) afirma que o objetivo do modelo GPTW é verificar a existência de correlação entre a satisfação funcional e o desempenho financeiro da empresa e destaca que dentre os fatores de impacto no desempenho da empresa no mercado econômico, as pesquisas que a empresa de consultoria GPTW vem realizando desde 1997, concluiu-se que "[...] um excelente lugar para se trabalhar é onde o individuo confia na organização, tem orgulho do que faz e gosta das pessoas com quem trabalha".

O autor deste modelo é Levering, (fundador do instituto) e possui seis caracteres de identificação transcritos a seguir:

Apropriação: indica como é percebido o grau com que o empregado é responsabilizado por suas ações;

Camaradagem: qualidade da hospitalidade, intimidade e comunidade no ambiente de trabalho, senso de equipe.

Credibilidade: grau de acesso e abertura nas comunicações, competência em coordenar os recursos humanos e materiais, integridade e consistência das decisões;

Imparcialidade: eqüidade, ou seja, tratamento equilibrado para todos em termos de recompensas, bem como ausência de favoritismo em recrutamento e promoção, não discriminação e possibilidade de apelação;

Orgulho: no trabalho realizado pelo indivíduo, no resultado alcançado por um membro ou pelo grupo, e nos produtos e serviços oferecidos pela empresa; e,

Respeito: suporte aos empregados em decisões relevantes, tratar os empregados como indivíduos com vida pessoal, apoiar o desenvolvimento profissional; 
Esse último modelo é o mais utilizado pelas empresas no Brasil, das quais a maioria se destaca no Guia Exame das 100 melhores empresas para se trabalhar.

[...] comparando os diversos modelos de pesquisa de clima organizacional, observa-se que os modelos mais abrangentes são o modelo de Sbragia e o modelo do Greate Place to Work Institute". Os dois modelos juntos conseguem abranger algo em torno de $80 \%$ de todos os itens pesquisados em todos os outros modelos (PEREIRA, 2003, p. 26).

De acordo com informações do GPTW (2007), a metodologia de avaliação utilizada pela empresa foi criada por Robert Levering, fundador do Instituto, como resultado de anos de pesquisas e entrevistas efetuadas em mais de 200 empresas nos EUA. "A metodologia de Levering demonstrou-se aplicável a empresas de diferentes setores e tamanhos, presentes em países com culturas distintas", e, portanto, se tornou o modelo mais utilizado pelas empresas quando o assunto é avaliação da satisfação de seus funcionários e do clima organizacional.

A metodologia de Levering vem sendo aplicada desde 1997 com o objetivo de elaborar as listas de "Melhores Empresas para Trabalhar". Segundo a empresa, a primeira lista brasileira foi publicada 1997, sendo o processo repetido nos Estados Unidos e publicada pela primeira vez em 1998. A partir dessas duas publicações principais, o Great Place to Work Institute desenvolve e publica listas de "Melhores Empresas" nas Américas do Norte e do Sul; na Europa e na Ásia.

Segundo informações do Instituto, as pesquisas realizadas têm demonstrado crescente interesse empresarial em melhorar a qualidade do ambiente de trabalho, pois permite inúmeras empresas, compararem sua política de gestão de pessoas e proceder as melhorias necessárias, indicando influência do clima organizacional com o desempenho financeiro das empresas, ou seja, quanto melhor o clima organizacional, melhor a relação com o cliente e, conseqüentemente, o desempenho financeiro das empresas.

Segundo Sehn (2005, p.33) "o Great Place to Work Institute já pesquisou o equivalente a um universo de mais de 10 milhões de funcionários em todo o mundo, em mais de 5000 empresas, o que torna uma referência mundial" e complementa:

Através do apoio à transformação dos ambientes de trabalho nas empresas - Institute espera construir uma sociedade melhor, disponibilizando ferramentas de diagnóstico e subsídios para implementação de ações de 
melhorias. Em 20 anos de atuação o Great Place to Work Institute vem avançando seus conhecimentos para se trabalhar nos Estados Unidos, Brasil e pelo mundo.

De acordo com Levering (apud SEHN, 2005, p.34) um excelente lugar para se trabalhar deve merecer a sua credibilidade em relação às pessoas que você trabalha, além de manter orgulho em relação ao local de trabalho e estar satisfeito com a equipe que integra.

Nesse aspecto o modelo GPTW privilegia o relacionamento entre chefes e subordinados; o relacionamento entre funcionários e a empresa onde trabalha; e a relação entre membros de uma equipe. Essas três perspectivas sobre o ambiente do trabalho devem estar em nível satisfatório para poder representar um clima organizacional ideal, ou seja, um clima propício à produtividade e ao desempenho pessoal de cada membro (SEHN, 2005, p. 35).

A autora (op. cit) cita a revista Fortune e destaca alguns resultados positivos com relação ao modo como as pessoas são tratadas em uma organização. Segundo ela, a disposição pessoal dos colaboradores "melhoram significativamente as vantagens competitivas disponíveis na organização", com destaque para as seguintes vantagens:

- recebem profissionais mais qualificados em seus processos de recrutamento;

- conseguiram um menor turnover, ou seja, há menor rotatividade no quadro funcional, representando menores despesas com novas contratações e treinamento desses novos funcionários;

- diminuíram custos com saúde, pois os funcionários ficam menos estressados e assim gozam de melhor disposição;

- alcançaram altos índices de satisfação e lealdade dos consumidores;

- promovem maior inovação e criatividade nos produtos e serviços, bem como nas soluções para processos de rotina;

- outros benefícios em decorrência da maior produtividade e lucratividade.

Segundo dados divulgados no site da empresa de consultoria Great Place to 
Work Institute (2007), os diversos estudos realizados pela empresa ao longo de seus 20 anos de atuação comprovam que as empresas que entram para a lista de "melhores empresas para se trabalhar" têm retorno imediato de seus investidores, concluindo que as empresas que investem em seus colaboradores, na realidade estão investindo nas próprias organizações.

Sehn (2005, p. 38) cita um estudo do Departamento de Trabalho dos Estados Unidos, comprovando o fenômeno de retorno descrito pela empresa de consultoria Great Place to Work Institute, e destaca:

A relação positiva entre treinamento, motivação com os funcionários resulta em aumentos da produtividade, satisfação interna e desempenho financeiro;

Quando você desenvolve e implementa uma estratégia de pessoas com progressivas práticas, a combinação de práticas é mais que uma prática em particular;

O impacto das práticas progressivas é maior no longo prazo ( 3 anos ou mais), indicando que as práticas precisam ser integradas ao ambiente de trabalho para prover benefícios.

De acordo com Vassalo (2004, p.26 e 27) o modelo Great Place to Work Institute proposto por Levering é um sucesso. Sobre a eficácia do modelo sugerido para avaliação de clima organizacional e, conseqüentemente, o investimento nas áreas deficitárias, diagnosticada pelo sistema de avaliação, a autora firma que as empresas que se dispõem a investir em seus funcionários, sentem significativa diferença na evolução da produtividade de modo geral, resultando no aumento da rentabilidade, inclusive.

Portanto, o que se pode concluir é que apesar do modelo GPTWI ser referência em termos de avaliação de clima organizacional, o fato de haver apenas clientes motivados não garante o sucesso da empresa. Entretanto, o presente estudo não contempla a avaliação mais ampliada sobre o sucesso das empresas pesquisadas, mas se limita a relacionar a condição do clima organizacional com a qualidade do atendimento, na opinião dos clientes das empresas pesquisadas.

Visando uma melhor qualidade no atendimento e uma melhor relação com seus clientes externos, as organizações têm investido em treinamento dos colaboradores no intuito de alcançar maior satisfação interna. Essa técnica é 
conhecida na administração como endomarketing.

O surgimento do endomarketing se deu a partir da década de 70 , oriundo da necessidade de se trabalhar as questões próprias do marketing como retratam as principais teorias sobre o tema. O objetivo primeiro era encantar os clientes internos das empresas e, como conseqüência, conquistar os clientes externos.

Com o ressurgimento da indústria japonesa, principalmente na área automobilística e eletrônica, e com o advento da globalização e a concorrência cada vez mais acirrada, gerou-se a necessidade das empresas alcançarem níveis de produtividade e qualidade cada vez mais elevados. Tais mudanças trouxeram reflexos diretos na forma de administrar que passou a buscar diferenciação pelo serviço e fidelização do cliente. Só que para fidelizar o cliente era preciso dar o melhor atendimento possível a esse cliente.

Juntamente com novas ferramentas para a Nova Administração, tais como: Reengenharia, Benchmarking e Qualidade Total, surge o Endomarketing como uma promessa para elevar o nível de competição através da melhoria da comunicação interna das organizações.

Os japoneses foram os pioneiros no desenvolvimento do Endomarketing e os americanos perceberam que a chave do sucesso japonês estava na valorização dispensada ao fator humano. Não bastava somente a qualificação técnica, pois a qualidade humana do comportamento e da iniciativa se constituíam a força motriz que levava à vantagem competitiva e à liderança eficaz.

Um dos executivos pioneiros na prática do endomarketing foi Saul Faingaus Bekin. Ele percebeu a necessidade de se trabalhar a comunicação entre departamentos, pois essa era uma área crítica na empresa. Além disso, Bekin constatou a ausência de visão dos colaboradores a respeito da empresa em que atuavam, o que dificultava o entendimento do papel e importância de cada um no contexto organizacional. Bekin percebeu que as ferramentas de marketing que precisava já existiam, o que faltava era adaptá-las à realidade interna da empresa.

Dessa forma, e graças à necessidade de uma ferramenta para promover a harmonia e a reordenação interna da empresa, surge o Endomarketing como importante instrumento interno para melhoria da ambiência de trabalho. Para agradar o cliente externo são necessários, primeiramente, atentar para os valores de 
cooperação no trabalho e envolver o cliente interno nos programas e objetivos da organização.

De acordo com Levitt apud Bekin (2004, p.5) "se a empresa espera atingir objetivo lá fora, precisa se certificar que todos nela estão comprometidos com esse objetivo".

\subsubsection{Requisitos para propiciar o melhor clima organizacional}

Não é difícil perceber que as exigências para a satisfação dos clientes estão cada vez mais presentes no dia a dia das empresas. Oferecer mais comodidade, facilidade e agilidade na transação de produtos ou serviços tem sido uma das principais preocupações das empresas realmente competitivas no mercado. Entretanto, a intensidade com que essas exigências avançam causam certo desconforto nos trabalhadores, pois nem todas as pessoas conseguem acompanhar e implementar tais reclamações do mercado consumidor. O resultado é o estresse no ambiente do trabalho e a conseqüente queda na qualidade do clima organizacional (GPTWI, 2007).

Segundo o Instituto MVC (2007), há pesquisas na área de clima organizacional indicando que trabalhadores insatisfeitos e com baixo índice de motivação, tendem a utilizar apenas $8 \%$ de sua capacidade de produção. Na mesma pesquisa, ficou comprovado que trabalhadores motivados utilizam até $60 \%$ de sua capacidade de produção.

Nesse sentido, o Instituto MVC (2007) afirma que fatores como ambiência de trabalho, salário, programas de valorização do colaborador, entre outros aspectos associados às condições de trabalho; compensação justa e adequada; uso e desenvolvimento de capacidades; chances de crescimento e segurança permanente; integração social na empresa; o constitucionalismo na organização do trabalho; comunicações e programação dos serviços são considerados como requisitos para a melhoria do clima organizacional.

\subsection{Qualidade e clima organizacional}


Embora uma das variáveis do foco da pesquisa não seja a produtividade, mas sim a qualidade dos serviços oferecidos pelo Lakeside, torna-se relevante a abordagem sobre esse tema devido à relação entre produtividade e clima organizacional. Entende-se que a produtividade não contempla apenas a questão da quantidade produzida, mas a qualidade daquilo que se produz. Nessa perspectiva, faz-se sugestivo, observar alguns conceitos.

Segundo a Progestão Consulting (2007) produtividade pode ser interpretada como "a relação entre os resultados obtidos e os recursos disponíveis consumidos". Para a Progestão Consulting, alguns fatores essenciais estão contidos no termo produtividade, transcritos a seguir. Entre eles:

[...] Produzir cada vez mais e melhor, com máxima satisfação das necessidades dos clientes; o termo vem do latim productivus, que significa fértil, rendoso, proveitoso, profícuo; é diferente de produção que é simplesmente quantidade produzida, sem valor e uso e pode-se generalizar que a produtividade existe quando a produção tiver qualidade.

Como se percebe, o termo produtividade é mais amplo e abarca outros elementos tão importantes quanto à questão da quantidade produzida apenas, ou seja, também pressupõe, entre outras variáveis:

- conformidade com os requisitos, ou, adaptabilidade ao uso, adequação ao cliente e/ou usuário;

- atendimento perfeito de forma confiável (sem defeitos), acessível (baixo custo), segura e no tempo certo às necessidades do cliente; e,

- ausência de desperdício, é 'atitude’.

"[...] qualidade, produtividade e competitividade caminham juntos e estão interligados e interdependentes, pois a competitividade decorre da produtividade, e esta da qualidade" (PROGESTÃO CONSULTING, 2007).

De acordo com o Sebrae (2007), quando se estuda as questões alusivas à produtividade, busca-se "identificar, analisar e minimizar a influência de fatores que, de uma forma direta ou indireta, interferem para que algo indesejado distorça os resultados esperados".

Produtividade é minimizar cientificamente o uso de recursos materiais, mão- 
de-obra, máquinas, equipamentos etc., para reduzir custos de produção, expandir mercados, aumentar o número de empregados, lutar por aumentos reais de salários e pela melhoria do padrão de vida, no interesse comum do capital, do trabalho e dos consumidores. (JAPAN PRODUCTIVITY CENTER FOR SOCIAL - ECONOMICS DEVELOPMENT apud SEBRAE, 2007).

Essas idéias sobre produtividade certamente começaram com a teoria das tarefas de Frederick Taylor, original criador e participante mais destacado do movimento da Administração Científica no início do século XX.

Taylor trabalhava na empresa Midvale, e preocupou-se em analisar os problemas apresentados durante as operações. Quase um século depois, os mesmos problemas que despertaram a atenção de Taylor em 1911, ainda podem ser encontrados, com facilidade, nas empresas atuais. Dentre eles, Taylor (Apud MAXIMIANO 2000, p.47), cita os seguintes:

- a administração não tinha noção clara da divisão de suas
responsabilidades com o trabalhador; - havia conflitos entre capatazes e operários a respeito da quantidade da produção.

- não havia incentivos para melhorar o desempenho do trabalhador;

· não havia integração entre os departamentos da empresa;

- os gerentes pareciam ignorar que a excelência no desempenho significava recompensas tanto para eles próprios quanto para a mão-de-obra; e,

- os trabalhadores eram colocados em tarefas para as quais não tinham aptidão;

Como se vê, a lista acima parece ter sido feita recentemente. No entanto, o que importa para efeito de corroborar as idéias propostas neste trabalho é demonstrar que alguns problemas relativamente simples podem prejudicar significativamente a produtividade de uma organização, em todos os sentidos.

Um outro importante conceito sobre produtividade, surgiu da mente de Henri Fayol, considerado o fundador da Teoria Clássica da Administração. Fayol teve a 
oportunidade de demonstrar suas idéias em sua famosa publicação, datada de 1916 sob o título de "Administration Industrielle et Générale". Com o mesmo afinco de Taylor, Fayol defendia suas teorias como sendo a "coisa certa a fazer" para elevar os níveis de produção. Na mesma época em que Taylor e Fayol apostavam em suas idéias e esforçavam-se para aumentar a produtividade industrial, o psicólogo Elton Mayo dirigia uma pesquisa muito interessante e com foco no bem estar dos trabalhadores da Western Electric Company, visando determinar qual a relação existente entre a intensidade da iluminação e a produtividade dos operários. (PARANHOS, 2006, p.12).

\subsection{O atendimento como diferencial competitivo}

Há um equívoco com relação ao conceito de bom atendimento. Muitas pessoas consideram que atender bem um cliente é prestar um bom serviço. No entanto, atender bem é tão obrigatório e óbvio para uma empresa quanto a honestidade deve ser para um funcionário.

Para uma melhor compreensão do que seja o bom atendimento e, conseqüentemente, sua aplicação como diferencial competitivo, destacam-se alguns princípios do marketing.

Os principais conceitos de marketing podem ser melhor visualizados e entendidos no esquema a seguir: 


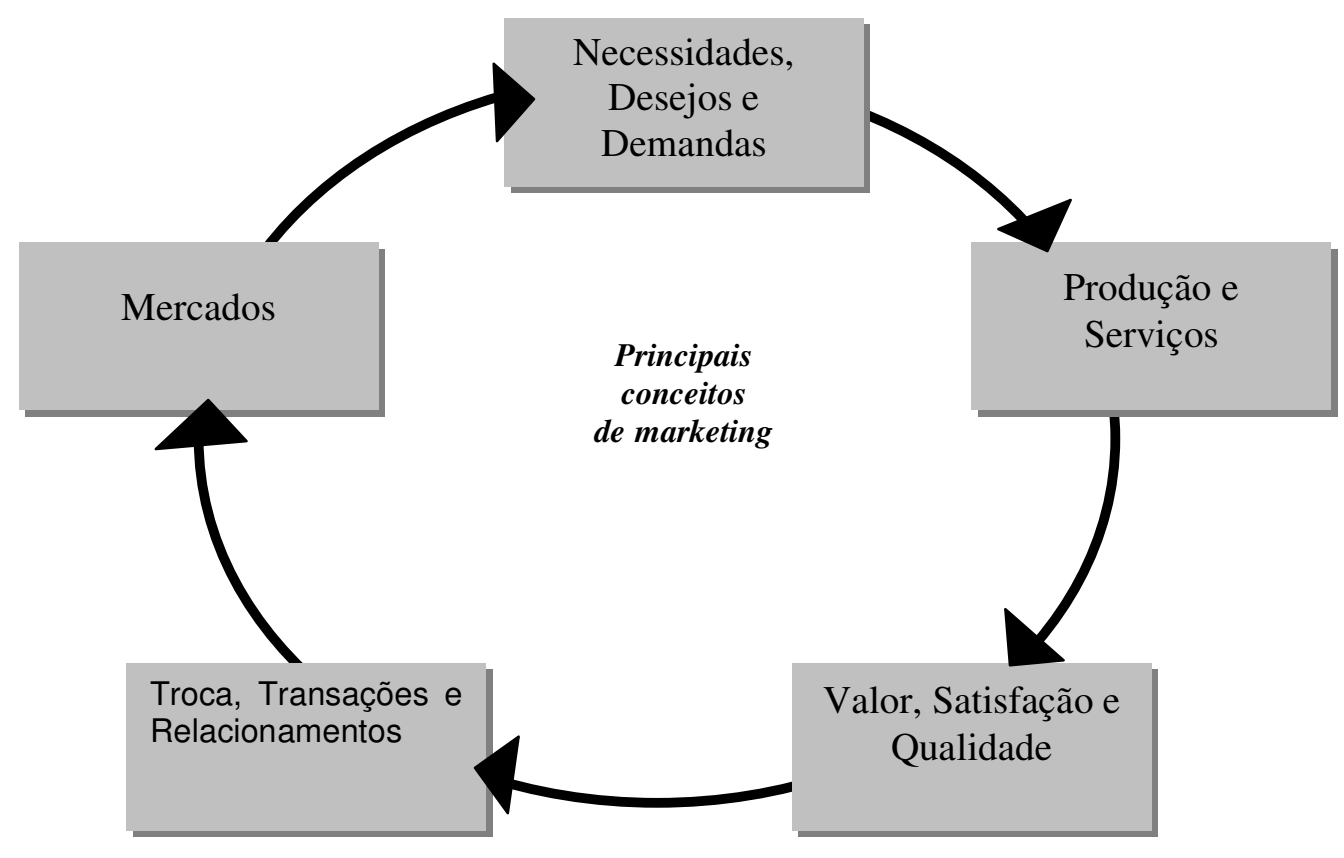

Figura 1: Principais conceitos em Marketing.

Fonte: McKENNA, Regis. Marketing de Relacionamento: estratégias bem-sucedidas para a era do cliente. Rio de Janeiro: Elsevier, 1997:23.

O esquema acima, como se pode perceber, demonstra claramente que não há uma hierarquia de importância entre as áreas estudadas em marketing, mas, o que existe é uma relação interdinâmica e que deve ser harmoniosa para atingir os objetivos a que se pretende, conforme McKenna (1997).

\subsubsection{Necessidades, desejos e demandas.}

Necessidades humanas estão relacionadas com algo imprescindível para a sobrevivência biológica ou social do indivíduo como o alimento, vestuário, abrigo e segurança, por exemplo. Essas necessidades podem resultar de um estado de privação de origem indeterminada. Essa origem pode ser voluntária ou involuntária, pode ainda ser de ordem intelectual, estética ou financeira, entre outras. O ser humano tem inúmeras necessidades que podem ser de ordem física ou social e essas necessidades precisam ser levadas em consideração na elaboração de estratégias mercantis que envolvem processos desde a fabricação de um produto ou oferta de um serviço até a aferição da satisfação e expectativas do cliente com relação ao produto ou ao serviço adquirido (McKENNA, 2007, p. 23). 
Segundo Kotler (1998, p.10)

produto é qualquer coisa que possa ser oferecida a um mercado para satisfazer uma necessidade ou desejo, sendo que o conceito de produto não se limita a objetos físicos e, qualquer coisa que satisfaça uma necessidade pode ser considerada como um produto.

Serviço, no entanto pode ser entendido como atividades ou benefícios oferecidos para venda, os quais são essencialmente intangíveis e não resultam na posse de nada. Alguns exemplos de serviços são bancos, companhias aéreas, hotéis, escritórios contábeis e serviços domésticos. Neste rol de 'prestadores de serviços' temos também o segmento de hotéis, objeto deste estudo (KOTLER, 1998).

Uma pessoa que compra uma furadeira, por exemplo, não precisa da furadeira, mas do furo que ela vai fazer. Logo, o que o cliente quer saber é se a furadeira vai fazer o furo do jeito que ele quer e do jeito que precisa (KOTLER, 1998).

Valor para o cliente, portanto, é a diferença entre o que ele ganha adquirindo e utilizando um produto e o que gasta para fazer a aquisição. Ou ainda o que ganha em termos de status ou valor de imagem. Geralmente os clientes não julgam o valor e os custos do produto de maneira precisa ou objetiva. Eles agem de acordo com o valor percebido (KOTLER, 1998).

A satisfação para o cliente depende do que ele percebe sobre o desempenho do produto em relação às suas expectativas. Se esse desempenho não corresponder às expectativas do cliente, o comprador ficará insatisfeito. Se exceder as expectativas, ele ficará maravilhado. As empresas referência em marketing se desdobram para manter seus clientes satisfeitos, pois clientes satisfeitos repetem suas compras e contam aos outros suas boas experiências com o produto (KOTLER, 1998).

Essa satisfação do cliente está estreitamente vinculada à qualidade do produto ou serviço oferecido. Neste sentido cada vez mais empresas estão aderindo a programas de gestão de qualidade total ou também conhecida pela sigla TQM como meio de fidelizar e manter seus clientes no maior índice de satisfação possível, pois gestão da qualidade representa melhoria constante dos produtos e serviços 
oferecidos e evolução interna no processo de marketing.

Os melhores prestadores de serviços estabelecem padrões de qualidade elevados. No site do SEBRAE pode-se ter acesso a artigos e estudos sobre a insatisfação de consumidores onde aponta que os clientes ficam insatisfeitos com suas compras cerca de $25 \%$ das vezes, mas apenas $5 \%$ deles reclamam. Os outros $95 \%$ acham que não vale a pena reclamar. Dos $5 \%$ dos consumidores que reclamam, apenas $50 \%$ relatam que houve uma solução satisfatória do problema. Supondo que, em média, um consumidor satisfeito fale a três pessoas sobre sua satisfação com a aquisição de um determinado produto ou serviço, por outro lado estima-se que o consumidor insatisfeito deva falar a pelo menos o dobro de pessoas, e isso explica-se por sua indignação por uma eventual frustração em uma relação de negócio (SEBRAE, 2007).

Por outro lado, os consumidores cujas reclamações foram satisfatoriamente solucionadas, tendem a confiar na empresa prestadora do serviço e assim ficam mais leais tornando constante suas relações de consumo, ao contrário do que acontece com aqueles consumidores insatisfeitos e que nunca reclamam, mas também não voltam a negociar com a empresa.

De acordo com Mckenna (1997) e Sebrae (2007), estima-se que $35 \%$ dos clientes de bens e serviços que registram suas insatisfações nas relações de compra tornam a adquirir o produto ou serviço reclamado, caso sejam atendidos. Nos casos de pequenas reclamações esse número pode elevar para 53\%. Isso significa que caso o consumidor seja atendido satisfatoriamente em sua reclamação, e o inconveniente ocorrido na relação de compra não chegue a abalar a confiança que esse cliente esteja desenvolvendo pela empresa, é muito provável que o cliente receberá um reforço positivo e voltará a fazer negócios com a mesma empresa.

Sugere-se que para aferir e administrar os índices de satisfação de seus clientes as empresas precisam facilitar o processo de reclamações, críticas ou sugestões, disponibilizando formulário adequado e de fácil acesso além de outros recursos tais como e-mail de acesso direto ao gerente ou diretor geral e, se possível, um departamento de atendimento ao cliente e até a disponibilidade de um ombudsman, espécie de 'ouvidor' especialmente designado para ouvir as eventuais queixas dos clientes e tomar as providências cabíveis em prazo hábil. 
Outro fator importante é o treinamento constante dos funcionários da empresa que recebem as reclamações com autonomia para resolver os problemas dos consumidores de maneira rápida e satisfatória.

Para manter um padrão elevado de qualidade na prestação de um determinado serviço a empresa deve primar não somente pela satisfação do cliente, mas também cuidar da satisfação de seus funcionários que lidam diretamente com os clientes - As empresas de serviços excelentemente administradas acreditam que as relações com os funcionários refletirão sobre as relações com os consumidores (SEBRAE, 2007).

Uma empresa deve zelar de forma equivalente pela satisfação de seus clientes, seus funcionários e seus fornecedores. Esta dinâmica garantirá satisfação entre todas as pessoas que têm a empresa como ponto comum de suas relações.

Juran (1990) define qualidade por meio de vários de seus aspectos arrolados em: desempenho do produto ou serviço e ausência de deficiências.

Como a ausência de defeitos pode ser relativa, pois cada cliente tem uma determinada expectativa, então Qualidade Total poderá ser definida como a ausência de defeitos na 'qualidade percebida'.

A qualidade percebida é a diferença entre a expectativa do cliente antes de consumir o produto ou serviço e a satisfação do cliente após adquirir o produto ou serviço.

\begin{abstract}
O significado do termo qualidade possui várias interpretações, sendo importante sua compreensão e definição, pois uma definição equivocada pode gerar problemas sérios para a empresa. Por exemplo, se a qualidade for considerada como algo abstrato, não existirão técnicas que levam a ela, ou, se qualidade for considerada como a perfeição, nutre-se a sensação de que nunca será alcançada. As conseqüências dessas definições refletem na gestão da qualidade (PARANHOS apud JURAN, 1990).
\end{abstract}

Segundo a Associação Brasileira de Normas Técnicas - ABNT, qualidade pode ser definida como "grau no qual um conjunto de características inerentes satisfaz a requisitos". Uma coleção desses requisitos da qualidade pode conter, entre outros itens: 
Confiabilidade: envolve tratar com coerência o desempenho e procurar ao longo do tempo manter constância de proposta e atitude.

Competência: significa possuir as habilidades necessárias para 0 bem servir e o conhecimento necessário para a sua execução.

Cortesia: envolve tratar com boas maneiras, respeito, consideração e contato amigável do pessoal com o mercado como um todo.

Credibilidade: envolve a confiança necessária, o crédito, a honestidade e o envolvimento concreto como s interesses, antes de tudo, do cliente.

Compreender e Conhecer o Cliente: envolve fazer um efetivo esforço para compreender todas as necessidades do cliente e demonstrar isto aplicando no dia-a-dia do atendimento.

Rapidez de resposta: diz respeito à disposição e à rapidez dos empregados para fornecerem o serviço esperado.

Acesso: envolve facilidade de estar sempre disponível, acessáveis, pronto para ser abordado, disposto a manter contato.

Comunicação: significa manter constantemente os cliente informados numa linguagem compreensível por eles. Além disto, demonstrar claramente que está sempre disposto a ouvir sobre as necessidades dos clientes.

Segurança: significa não deixar dúvidas quanto ao que vai ser "servido", não oferecer qualquer tipo de perigo ou risco.

Tangíveis: procurar tangibilizar os serviços através de evidências físicas que a qualificam o serviço desejado.

Neste sentido, considerando que a percepção do cliente é que determina o nível de qualidade de um produto ou serviço, entende-se que um mesmo produto ou um mesmo serviço pode ser avaliado de forma diferente por clientes distintos. Assim, não é a ausência de falhas e sim a percepção de cada cliente que definirá o nível de sua satisfação, conforme afirmam Kotler e Armstrong (1998b, p. 7) da seguinte forma:

De maneira simplista podemos definir qualidade como 'ausência de defeitos'. No entanto, muitas empresas voltadas para o cliente vão além dessa limitada definição de qualidade. Essas empresas definem qualidade em termos do nível de satisfação do cliente. Segundo a American Society for Quality Control qualidade é definida como sendo "o total de 
características de um produto ou serviço voltadas para satisfazer as necessidades dos clientes". Essas definições focalizadas no cliente sugerem que uma empresa alcança a qualidade total somente quando seus produtos ou serviços atendem às expectativas dos clientes ou as superam. (KOTLER e ARMSTRONG, 1998b, p.7).

A cada busca pela satisfação de uma necessidade, o cliente cria uma expectativa relacionada ao processo na satisfação dessa busca. Assim, cada cliente tem diferentes expectativas sobre um mesmo serviço ou produto. Nesse sentido, a empresa precisa preparar seus funcionários para prever e satisfazer o maior número possível de variações dessas expectativas dos clientes. Dessa forma, entende-se que a empresa estará apta para oferecer ao cliente aquilo que ele espera receber. É a avaliação do cliente, ao final da transação, que determinará a qualidade do serviço prestado.

3.4 A motivação como fator importante em gestão de pessoas

Para Lopes (1980, p.23) e Ribeiro (1994, p.32) a motivação está intrinsecamente relacionada com "sentimentos de realização e de reconhecimento profissional". Para os autores, essas sensações são manifestadas por meio de atividades que apresentem desafio compatível com as capacidades individuais e, necessariamente, façam sentido para o trabalhador.

[...] é o objetivo que se imagina possuído pelos outros e que em geral contamos encontrar em alguma meta imediata e notória, como ambição de dinheiro, desejo de segurança ou esforço para ter prestígio. No entanto, as metas pelas quais as pessoas parecem lutar, ao serem analisadas, freqüentemente são apenas meios de alcançar uma outra meta mais fundamental. Sendo assim, a riqueza, a segurança, a posição elevada e todas as demais metas, que supomos ser a "causa" do comportamento humano, não passam de instrumentos de que se serve o indivíduo para atingir seu verdadeiro objetivo, que é ter personalidade própria (BOSS, 1997, p.30).

Bergamini (1997, p. 45) leciona que o senso comum entendia a motivação como sendo fruto de objetivos motivacionais genéricos, sem um alvo determinado. Essa idéia fora amplamente difundida por Maslow, McGregor e, inclusive, por Herzberg. De acordo com essa idéia, as pessoas precisam satisfazer certas necessidades ou objetivos elementares para só então focarem outros, a exemplo da 
teoria das necessidades humanas de Maslow. É indubitável que a consecução de tais objetivos produzem satisfação ao indivíduo.

Entretanto, embora não discorde dessa teoria tradicional da motivação, é importante o enfoque motivacional com base na psicodinâmica interna da pessoa. (CHIAVENATO, 1991, p. 33). 


\section{ORGANIZAÇÕES ESTUDADAS}

\subsection{A Rede Atlantica Hotels}

De acordo com informações postadas no site da Atlantica (2007), a Barrington Hotels \& Resorts BIH LTD, responsável pela administração de 68 hotéis na Europa, em 1996, por meio de sua subsidiária Choice Hotels Empreendimentos do Brasil, inicia operações no país. No início, atuava somente como franqueador das bandeiras Choice: Sleep Inn, Comfort e Quality.

Em 1998, a entra em operação do primeiro hotel aberto pela Atlantica Hotels, o Comfort Hotel Trianon Park, que depois passou a se chamar Comfort Hotel Paulista. Em 1999, a rede inaugura o Sleep Inn Galeria na cidade de Campinas, São Paulo, somando na época três empreendimentos.

Em 2000, outros três empreendimentos são lançados, entre eles: Sleep Inn de Ribeirão Preto; Quality Suítes Metrópolis em São Paulo, capital e o Comfort Hotel Ilha do Leite, em Recife.

Em 2001 a rede altera sua razão social para Atlantica Hotels International, com o objetivo viabilizar a expansão da empresa para o segmento quatro e cinco estrelas. A Atlantica Hotels International passe a liderar o segmento de administradora hoteleira e se torna a maior empresa independente de administração hoteleira da América do Sul. Sua estratégia principal foi o estabelecimento de acordos preferenciais multimarcas.

Posteriormente, mas no mesmo ano, estabelece parceria com a master franqueadora Starwood Hotels e inaugura o Four Points Sheraton na cidade de Curitiba, e o Quality Resort Lins. Nesse período a expansão de empreendimentos chega a marca de 19 hotéis. Dentre os empreendimentos, destaca-se o Quality Resort Lakeside, em Brasília.

Na capital do País a rede incorpora no ano seguinte (2002) outros dois grandes empreendimentos: O Metropolitan Flat e o Bonaparte Hotel.

Ainda em 2002 a rede lança o Cartão Preferencial Atlantica Gold, uma iniciativa inédita no mercado hoteleiro com benefícios exclusivos para seus 
investidores, que permite desconto nas diárias em qualquer empreendimento da rede no Brasil, inclusive para seus familiares.

O ano de 2003 foi marcado pela criação do cargo de Vice Presidente de Recursos Humanos com a promoção da diretora de $\mathrm{RH}$, Dináurea Cheffins, concomitante com a reestruturação dos canais de vendas e reformulação da Central de Reservas. Em abril do mesmo ano, a Atlantica Hotels inova mais uma vez e lança o Andar Feminino em toda a rede com bandeiras Quality, Clarion, Four Points By Sheraton e Radisson.

O complexo hoteleiro adota o Programa "Selo Azul", para garantir o padrão de qualidade internacional nos serviços e instalações em toda a rede e o Comfort Suítes Campinas é nomeado um dos cinco finalistas para o prêmio "2003 Hotel of The Year", promovido pela rede Choice Hotels International.

Em 2003 a Atlantica Hotels abriu 16 empreendimentos sendo a primeira inauguração do ano o Quality Jardins em São Paulo e o último o Beach Class suítes em Recife. A empresa fecha o ano de 2003 com 43 empreendimentos em plena operação. Nesse ano, a Atlantica Hotels recebe o prêmio da revista Exame e Você S/A por constar na lista das 150 melhores empresas para se trabalhar.

A implantação do serviço de andar feminino nas marcas Quality, Clarion, Four Points e Radisson garantiu para a Atlantica Hotels o Prêmio de Inovação de Serviços, concedido pela revista 4 Rodas da editora Abril. Na mesma época, a empresa comemora o sucesso da campanha Final de Semana Inesquecível, tendo cadastrado mais de 15.000 participantes em seu site.

O ano de 2004 foi marcado pela abertura do Comfort Inn, em Taguatinga e o Comfort da cidade de Franca, interior de São Paulo. A Atlantica Hotels chega a 50 unidades em operação e entrega 47 prêmios Selo Azul, Selo Ouro e Gold Award, em reconhecimento à qualidade das unidades, e o President's Award aos colaboradores de destaque durante a VI Convenção Anual no Quality Resort \& Convention Lins. Radisson recebe o President's Award do Grupo Carlson pelo segundo ano consecutivo.

Os resultados de 2004 conferiram aos Executivos da Atlantica prêmios por reconhecimento e três unidades concorrem ao título de Melhor Hotel do Ano pela Choice Hotels Internacional. 
De acordo com informações no site oficial da Atlantica Hotels, em setembro de 2004, Carlos Eduardo Santos, Roberto Bertino e Rachel Golfetto, executivos da Atlantica Hotels recebem o Certified Hotel Administrator concedido pelo Educational Institute of the American Hotel and Lodging Association (AH\&LAs Educational Institute) em reconhecimento à excelência profissional.

No mesmo ano, a Atlantica Hotels inova mais uma vez, agora com redução de custos operacionais por meio do Data Inn, sistema inédito de tráfego de dados e telefonia interna, desenvolvido pelo departamento de tecnologia de Informação da Empresa, em parceria com a Linktel. A empresa fecha o ano com chave de ouro patrocinando o evento da revista Forbes: As Mulheres mais Influentes do Brasil.

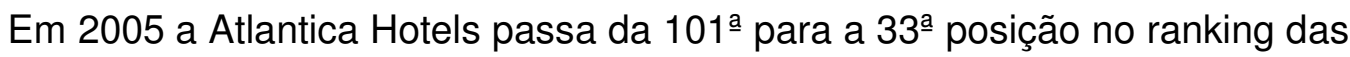
empresas top em administração hoteleira no mundo, editado pela revista Lodging Magazine. Iniciam-se as operações de restaurantes próprios pelo grupo, oferecendo maior qualidade dos serviços.

Em novembro de 2005, a Atlantica Hotels é eleita como a Melhor Empregadora da América Latina pela revista América Economia e em dezembro conclui o ciclo de treinamento e reciclagem de todos os gerentes gerais da rede.

De acordo com informações institucionais, atualmente são 10 bandeiras divididas em três segmentos, da seguinte forma: Econômico: Go Inn, Sleep Inn, Comfort e Park Inn. Superior: Comfort Suites, Quality e Park Suites. Luxo: Clarion, Four Points e Radisson.

Como diferencial competitivo, os empreendimentos administrados pela Atlantica Hotels oferecem o mesmo conjunto de vantagens e atrativos, como:

- Programa $100 \%$ Satisfação Garantida, através do qual o dinheiro é devolvido caso haja algum problema que não possa ser corrigido durante a permanência do hóspede;

- Café da manhã cortesia em todas as categorias de hotéis da rede;

- Andar feminino, com exclusivo serviço e decoração disponíveis na maioria dos hotéis das categorias Superior e Luxo, para maior conforto e privacidade;

- Acesso à internet gratuito

A política de Recursos Humanos é arrojada e, entre os benefícios oferecidos 
aos seus colaboradores, destacam-se: Alimentação; uniforme; assistência médica inclusive para os dependentes; vale transporte; seguro de vida em grupo; custeio total de viagens à serviço; celular para os colaboradores em cargos de gerência; sistema de reconhecimento e desenvolvimento cujo objetivo é reconhecer o melhor colaborador do mês ou bimestre. O colaborador premiado recebe uma bonificação de $50 \%$ do salário nominal, no mês / bimestre e 100\% do salário nominal como Funcionário do ano. Além disso, o Lakeside oferece também programas de treinamento e acompanhamento profissional, visando o desenvolvimento profissional do colaborador e a viabilização de um plano de carreira dentro da empresa.

O Lakeside mantém Programa de pesquisa de satisfação do colaborador, permitindo que seus funcionários expressem suas opiniões sobre a empresa, revelando o seu nível de satisfação com relação à organização. Dentre os tópicos abordados, destacam-se: Relacionamento, Comunicação, Treinamento \& Desenvolvimento, Reconhecimento e Condições de Trabalho, Plano de ação de cada hotel para obter os resultados.

\subsection{Caracterização do Quality Resort Lakeside}

O Lakeside foi inaugurado em 2001. Fica às margens do Lago Paranoá, em Brasília, Capital Federal e dispõe de 120 apartamentos, além de toda infra-estrutura de esporte e lazer para seus hóspedes (ATLANTICA HOTELS, 2007).

$\mathrm{Na}$ qualidade de resort o Lakeside fica distante do centro de Brasília e, em compensação, oferece a tranqüilidade peculiar dos empreendimentos construídos com essas características, atraindo um público que busca mais o lazer do que os negócios, embora o hotel tenha toda infra-estrutura para a realização de convenções e outros eventos.

Dentre os itens que disponibiliza aos seus clientes cita-se: Piscina adulta e infantil, oferece atividades náuticas, bar da piscina, bar molhado, business center, centro de convenções, coffee shop, equipe de recreação, estacionamento, fitness center, kids club, lavanderia, lobby bar, loja de conveniências, marina, quadra poliesportiva, quadras de tênis, sala de massagem, sauna a vapor, solarium, spa, traslado free - hotel / setor autarquias e hotel / setor comercial, andar para não- 
fumante, apartamento conjugado, apartamento para não-fumante, long stay equipados com mini-cozinha e geladeira, 02 apartamentos para portadores de necessidades especiais, linha telefônica nos apartamentos, ar condicionado individual, banheira, cofre eletrônico, dvd player, isolamento acústico, menu de travesseiros, mesa de trabalho com conexão para internet banda larga, microondas, mini-bar, pay per view, rádio-relógio, sacada, secador de cabelos, tv a cabo, tv tela plana.

O Hotel oferece ao público das classes A e B infra-estrutura em hospitalidade e lazer. O hotel conta com todos os itens da categoria "Superior" e oferece ainda loja de conveniência, spa e academia, entre outros serviços.

De acordo com Sistare (2007, p.7), presidente da Atlantica Hotels International, administradora da bandeira Lakeside, a organização "assume muitas obrigações com seus colaboradores enquanto empregador", e complementa:

[...] somente desta forma criaremos uma atmosfera de confiança e respeito mútuo. Sabemos que o crescimento da Empresa depende do envolvimento de pessoas competentes e motivadas. Desta forma, vamos incentiva-lo a crescer profissionalmente, para que juntos alcancemos o sucesso.

Outro programa realizado pela empresa é o de Prevenção de Acidentes no Trabalho, aumentando o senso de segurança de seus colaboradores.

Atualmente o Lakeside conta com 110 colaboradores, cujo perfil pode ser melhor detalhado, conforme pesquisa realizada com 34 desses funcionários, cuja amostragem representa $31 \%$ do total do efetivo.

\subsection{Caracterização do Metropolitan Flat}

Ao contrário do Lakeside, o Metropolitan está localizado no centro de Brasília, dentro do pólo comercial e político da Capital Federal e a quinze minutos do aeroporto internacional JK. Enquanto a estrutura do Lakeside está disposta em uma área mais ampla e, por isso, sua estrutura arquitetônica é horizontalizada, no Metropolitan, a estrutura arquitetônica é verticalizada, por razões óbvias aos grandes empreendimentos construídos no centro dos principais centros urbanos. Dessa 
forma, mesmo oferecendo a mesma quantidade de apartamentos e mantendo a mesma qualidade dos serviços, no Metropolitan o hóspede tem a opção de estar próximo de shoppings, bancos, ministérios e do Congresso Nacional, enquanto no Lakeside o hóspede tem outras opções como marina e centro de convenções, por exemplo (ATLANTICA HOTELS, 2007).

Assim como no Lakeside, o Metropolitan também possui 120 apartamentos (flats). Cada unidade é equipada com duas televisões, vídeo, TV a cabo, conectividade (Internet), umidificador de ar, geladeira, microondas, tostadeiras, entre outros equipamentos (ATLANTICA HOTELS, 2007).

A infra-estrutura do Metropolitan oferece aos seus hóspedes: sala de reunião, internet, sala de ginástica, sala de jogos, piscinas e duas versões de um dos mais tradicionais restaurantes de Brasília (ATLANTICA HOTELS, 2007).

Atualmente o Metropolitan conta com 78 colaboradores, cujo perfil pode ser melhor detalhado, conforme pesquisa realizada com 24 desses funcionários, cuja amostragem representa $31 \%$ do total do efetivo (ATLANTICA HOTELS, 2007). 


\section{METODOLOGIA}

Silva (2005, p.33) define a metodologia como "um conjunto de procedimentos intelectuais e técnicos utilizados para atingir determinado objetivo, nesse caso, conhecimento".

Gil (apud SILVA, 2005, p.33) diz que "existe uma diversidade de métodos científicos" e classifica-os como gerais e específicos. Os métodos gerais proporcionam a base lógica para a investigação e os métodos específicos são métodos de raciocínio que indicam os procedimentos técnicos que serão adotados. Portanto, a técnica sempre estará sujeita aos métodos.

Segundo Barros e Lehefeld (2000, p.2) a metodologia busca mostrar ao pesquisador que se pode adquirir conhecimento por meio da pesquisa científica e 0 autor se refere ao pesquisador como sujeito do processo.

Dentre os métodos de pesquisa, Silva (2005, p. 34) cita os seguintes:

a) Método Indutivo: aquele que parte das questões particulares para as mais generalizadas.

Para Marconi e Lakatos (2000, p. 53), o método indutivo "[...] é um processo mental por intermédio do qual, partindo de dados particulares, suficientemente constatados, infere-se uma verdade geral ou universal, não contida nas partes examinadas".

Dessa forma, a finalidade da argumentação do método indutivo é extrair conclusões "cujo conteúdo é muito mais amplo do que o das premissas nas quais se basearam" (MARCONI e LAKATOS, 2000, p.53).

b) Método Dedutivo: aquele que pressupõe a existência de verdades gerais, previamente afirmadas, no intuito de servirem como base para a aquisição de novos conhecimentos (SILVA, 2005, p. 35).

c) Método Hipotético-dedutivo: aquele cujo raciocínio implica a dedução de certas conclusões com base apenas nas hipóteses (SILVA, 2005, p. 37).

d) Método dialético: "que penetra o mundo dos fenômenos através de sua ação recíproca, da contradição inerente ao fenômeno e da mudança 
dialética que ocorre na natureza e na sociedade" (MARCONI e LAKATOS, 2001, p. 106).

Dentre as variadas possibilidades, optou-se pelo método dedutivo, pois tal abordagem tem como fundamentos teóricos os estudos já existentes sobre clima organizacional e qualidade no atendimento, e realiza uma análise comparativa de fenômenos específicos nos hotéis Lakeside e Metropolitan Flat.

\subsection{Tipo de pesquisa}

Dentre os tipos de pesquisa destacados por Silva (2005, p.36), cita-se:

a) Pesquisa Exploratória: aquela que busca aprimorar uma idéia préexistente com base em levantamento bibliográfico, além de entrevistas e análises de exemplos similares.

b) Pesquisa Descritiva: Sua finalidade é descrever certos fenômenos ou estabelecer relações entre variáveis. Neste tipo de pesquisa utiliza-se o questionário como técnica de coletas de dados, além da observação sistemática.

c) Pesquisa Explicativa: aquela que busca a identificação de fatores determinantes ou que contribuem de certa forma para a consecução de dado fenômeno.

Para a realização deste trabalho, optou-se pelo tipo de pesquisa descritiva, pois tenta descrever um fenômeno de influência entre o clima organizacional e a qualidade no atendimento, com base na utilização de um questionário de pesquisa.

\subsection{Instrumentos de coleta de dados}

Segundo Marconi e Lakatos (2001, p. 115) o procedimento de coleta dos dados pesquisados pode ser a pesquisa bibliográfica, "[...] desenvolvida a partir de material já elaborado: livros e artigos científicos". 
Para Denker (2004, p.125) a pesquisa documental também é um instrumento de coleta de dados. Entretanto, sua característica se difere da pesquisa bibliográfica, pois utiliza material sem tratamento analítico, possibilitando sua reelaboração, a exemplo dos registros de hóspedes de formulários de avaliação de satisfação de cliente, entre outros, conforme afirma o autor, nas seguintes palavras:

As fontes documentais podem ser documentos de primeira mão conservados em arquivos de instituições públicas e privadas (formulários da Embratur, registro de hóspedes) ou pessoais (diários, relatos de viagem). Além desses temos documentos de segunda mão: relatórios (de pesquisa, de empresas) e dados estatísticos (IBGE). DENCKER (2004, p. 125).

De acordo com Silva (2005, p.40), além das pesquisas bibliográfica e documental, considera-se também como instrumento de coleta de dados a pesquisa experimental, que por sua vez, "consiste em verificar as alterações causadas por uma determinada variável no objeto escolhido para estudo". A autora revela ainda que há outras inúmeras possibilidades de coleta de dados, podendo inclusive sofrer adaptações para atender as necessidades de cada pesquisador

Nesse sentido, para a realização do presente trabalho optou-se pela aplicação de questionário (anexo I) aos funcionários do Quality Resort Lakeside e Metropolitan flat, contendo 34 perguntas referentes às condições gerais de trabalho do hotel, de acordo com o modelo adotado pela empresa de consultoria The Great Place to Work Institute, além da pesquisa documental dos registros de satisfação do cliente mantidos pela Atlantica Hotels.

\subsection{Procedimento de análise de dados}

Os dados coletados foram tabulados utilizando-se do programa Microsoft Excel, possibilitando a disposição comparativa em tabelas. Ao comparar as informações colhidas tanto na pesquisa de clima organizacional realizada com as equipes dos dois hotéis com os resultados de satisfação dos clientes do Quality Resort Lakeside e Metropolitan Flat, foi possível observar as variações de satisfação nas atividades que demandam interação direta com o cliente.

Dessa forma, buscou-se conhecer a influência direta do clima organizacional 
sobre a qualidade dos serviços prestados.

Ao identificar possíveis relações entre o clima organizacional e a qualidade dos serviços, poderá ser sugerida algumas ações no sentido de potencializar a qualidade dos serviços prestados pelos funcionários do Quality Resort Lakeside. 


\section{ANÁLISE E INTERPRETAÇÃO DOS DADOS}

Para a realização da pesquisa foram escolhidos 34 funcionários do hotel Lakeside e 24 do Metropolitan Flat, tendo sido distribuído o questionário de pesquisa, conforme Anexo I, e solicitado o preenchimento consensual, sem que fosse necessária a identificação pessoal. Os funcionários que aceitaram responder os questionários foram instruídos a devolver o instrumento de pesquisa preenchido em até 48 horas, sendo orientados a marcarem as questões que melhor se adequavam à opinião dos respondentes.

\subsection{Perfil dos colaboradores respondentes}

\begin{tabular}{|c|c|c|c|c|}
\hline \multirow[t]{2}{*}{ Gênero } & \multicolumn{2}{|c|}{ Lakeside } & \multicolumn{2}{|c|}{ Metropolitan } \\
\hline & Frequência & $\%$ & Frequência & $\%$ \\
\hline Masculino & 24 & 71 & 4 & 17 \\
\hline Feminino & 10 & 29 & 20 & 83 \\
\hline Totais & 34 & 100 & 24 & 100 \\
\hline
\end{tabular}

Tabela 1 - Respondentes por gênero

Fonte: Pesquisa direta

Em relação ao gênero, embora não haja distinção por parte da administração dos hotéis pesquisados para efeito de contratação, verificou-se que do total de respondentes, a população de colaboradores femininos é maior no Metropolitan do que no Lakeside, conforme demonstra a tabela 1.

\begin{tabular}{c|c|c|c|c}
\hline \multirow{2}{*}{ Faixa etária } & \multicolumn{2}{|c|}{ Lakeside } & \multicolumn{2}{c}{ Metropolitan } \\
\cline { 2 - 5 } & Frequência & $\%$ & Frequência & $\%$ \\
\hline 16 a 30 anos & 26 & 76 & 18 & 75 \\
\hline 31 a 45 anos & 6 & 18 & 5 & 21 \\
\hline Acima de 45 anos & 2 & 6 & 1 & 4 \\
\hline Totais & $\mathbf{3 4}$ & $\mathbf{1 0 0}$ & $\mathbf{2 4}$ & $\mathbf{1 0 0}$ \\
\hline
\end{tabular}

Tabela 2 - Respondentes por idade

Fonte: Pesquisa direta

Com relação à idade, a maioria dos colaboradores dos dois hotéis pertence à faixa etária jovem-adulto com idades entre 16 e 30 anos, representando $76 \%$ da força de trabalho no Lakeside e $75 \%$ no Metropolitan; os respondentes com idade entre 31 e 45 anos representam $18 \%$ do efetivo do Lakeside contra $21 \%$ no Metropolitan e apenas $6 \%$ dos entrevistados possuem idade acima de 45 anos no Lakeside, contra 4\% no Metropolitan, conforme tabela 2. 


\begin{tabular}{l|c|c|c|c}
\hline \multirow{2}{*}{ Tempo de serviço } & \multicolumn{2}{|c|}{ Lakeside } & \multicolumn{2}{c}{ Metropolitan } \\
\cline { 2 - 5 } & Frequência & $\%$ & Frequência & $\%$ \\
\hline até 2 anos & 24 & 70 & 20 & 83 \\
\hline de 3 a 5 anos & 8 & 24 & 4 & 17 \\
\hline de 6 a 10 anos & 0 & 0 & 0 & 0 \\
\hline acima de 11 anos & 2 & 6 & 0 & 0 \\
\hline Totais & 34 & 100 & 24 & 100 \\
\hline
\end{tabular}

Tabela 3 - Respondentes por tempo de serviço

Fonte: Pesquisa direta

Na tabela 3 verifica-se que a maioria dos colaboradores do Lakeside, cerca de $70 \%$, têm até dois anos de serviço, enquanto $24 \%$ têm entre três e cinco anos de serviço no hotel e apenas 6\% têm mais de 11 anos de serviço. Quanto ao Metropolitan, assim como no Lakeside, a maioria dos colaboradores, cerca de $83 \%$, têm até dois anos de serviço e $17 \%$ têm entre 3 e 5 anos de casa.

\begin{tabular}{|c|c|c|c|c|}
\hline \multirow[t]{2}{*}{ Escolaridade } & \multicolumn{2}{|c|}{ Lakeside } & \multicolumn{2}{|c|}{ Metropolitan } \\
\hline & Frequência & $\%$ & Frequência & $\%$ \\
\hline Ensino Fundamental & 0 & 0 & 0 & 0 \\
\hline Ensino Médio & 4 & 18 & 2 & 0 \\
\hline Ensino Superior incompleto & 10 & 58 & 20 & 84 \\
\hline Ensino Superior completo & 3 & 24 & 2 & 8 \\
\hline Pós-graduação & 0 & 0 & 0 & 8 \\
\hline Outro & 0 & 0 & 0 & 0 \\
\hline Totais & 34 & 100 & 24 & 100 \\
\hline
\end{tabular}

Tabela 4 - Respondentes por escolaridade

Fonte: Pesquisa direta

A tabela 4 revela que a escolaridade média dos colaboradores, em ambos os hotéis, é de Ensino Superior Incompleto, representando $58 \%$ do efetivo no Lakeside e 84\% no Metropolitan.

Apesar da escolaridade de nível superior ser um dos requisitos para contratação dos colaboradores da Rede Atlantica, não há estudos que comprovem a influência da escolaridade sobre o clima organizacional ou mesmo sobre a satisfação dos clientes. 


\begin{tabular}{|c|c|c|c|c|}
\hline \multirow[t]{2}{*}{ Estado civil } & \multicolumn{2}{|c|}{ Lakeside } & \multicolumn{2}{|c|}{ Metropolitan } \\
\hline & Frequência & $\%$ & Frequência & $\%$ \\
\hline Solteiro(a) & 16 & 47 & 12 & 50 \\
\hline Separado(a) / Divorciado(a) & 0 & 0 & 0 & 0 \\
\hline Casado(a) & 14 & 41 & 8 & 33 \\
\hline Viúvo(a) & 0 & 0 & 0 & 0 \\
\hline União estável & 4 & 12 & 4 & 17 \\
\hline Totais & 34 & 100 & 24 & 100 \\
\hline
\end{tabular}

Tabela 5 - Respondentes por estado civil

Fonte: Pesquisa direta

Com relação ao estado civil dos respondentes, a maioria dos colaboradores nos dois hotéis pesquisados marcou a opção "solteiro", representando 47\% e 50\% no Lakeside e Metropolitan, respectivamente. Não houve registro de colaboradores separados ou viúvos em ambos os hotéis, conforme se observa a tabela 5.

Com base nos dados coletados, observa-se diferença significativa na composição das duas equipes em relação ao gênero, pois enquanto no Lakeside predomina a população masculina de colaboradores, no Metropolitan é a população feminina que predomina.

Não há qualquer razão específica e aparente para essa diferença no perfil dos colaboradores. Contudo, os demais dados se mostraram proporcionalmente eqüitativos em relação ao perfil dos respondentes.

Não se encontrou qualquer pesquisa ou estudo mais significativo sobre diferenças qualitativas no atendimento e na qualidade do clima organizacional em relação ao gênero dos colaboradores e, por isso, não se pode afirmar qualquer vantagem tanto no atendimento aos clientes dos hotéis pesquisados, quanto na qualidade do clima organizacional em função da predominância de um determinado gênero na equipe.

\subsection{Avaliação do clima organizacional}

Para identificar o grau de satisfação dos funcionários dos hotéis Lakeside e Metropolitan e, conseqüentemente, do clima organizacional para posteriormente fazer uma comparação com a satisfação dos clientes de ambos os hotéis, procedeuse a aplicação de questionário contendo 34 afirmativas e cinco opções de respostas: 
Discordo totalmente, discordo parcialmente, indiferente, concordo parcialmente, e concordo totalmente.

A estrutura do questionário segue o modelo utilizado pela empresa de consultoria The Great Place to Work Institute, por ser esse modelo o que melhor se adequa a esse tipo de pesquisa, sendo inclusive eficaz instrumento utilizado para verificar "As 100 melhores empresas para se trabalhar" divulgado periodicamente pela revista Exame e Época.

O modelo sintetiza as principais teorias sobre clima organizacional e, para efeito de representação gráfica, as afirmativas foram reagrupadas em seis caracteres indicativos de satisfação laboral: Apropriação, camaradagem, credibilidade, imparcialidade, orgulho e respeito.

Importante salientar que todas as afirmativas do questionário são positivas, sugerindo uma situação ideal em relação às categorias pesquisadas e, dessa forma, as respostas discordantes apontam insatisfação e as respostas concordantes apontam a satisfação por parte do colaborador conforme os itens pesquisados. Assim, quanto maior for o índice de respostas concordantes, maior será o grau de satisfação do colaborador com o quesito pesquisado. Nesta mesma perspectiva, quanto maior for o índice de respostas discordantes, maior será o grau de insatisfação.

\begin{tabular}{|l|l|l|}
\hline Categoria & Descrição & $\begin{array}{l}\text { Afirmativas do questionário } \\
\text { de pesquisa }\end{array}$ \\
\hline Apropriação & $\begin{array}{l}\text { Indica como é percebido o grau com } \\
\text { que o empregado é responsabilizado } \\
\text { por suas ações }\end{array}$ & $8,16,21,27,29$ e 34 \\
\hline Camaradagem & $\begin{array}{l}\text { Qualidade da hospitalidade, } \\
\text { intimidade e comunidade no ambiente } \\
\text { de trabalho, senso de equipe }\end{array}$ & 5,14 e 25 \\
\hline Credibilidade & $\begin{array}{l}\text { Grau de acesso e abertura nas na } \\
\text { comunicações, competência em em } \\
\text { coordenar os recursos humanos e } \\
\text { materiais, integridade e consistência } \\
\text { das decisões }\end{array}$ & $2,3,4,7,13,22,28$ e 30 \\
\hline Imparcialidade & $\begin{array}{l}\text { Eqüidade, ou seja, tratamento } \\
\text { equilibrado para todos em termos de } \\
\text { recompensas, bem como ausência de } \\
\text { favoritismo em recrutamento e e } \\
\text { promoção, não discriminação e e } \\
\text { possibilidade de apelação }\end{array}$ & $1,19,20$ e 33 \\
\hline
\end{tabular}




\begin{tabular}{|c|c|c|}
\hline Orgulho & $\begin{array}{l}\text { No trabalho realizado pelo indivíduo, } \\
\text { no resultado alcançado por um } \\
\text { membro ou pelo grupo, e nos } \\
\text { produtos e serviços oferecidos pela } \\
\text { empresa }\end{array}$ & $9,11,12,15,17,23$ e 26 \\
\hline Respeito & \begin{tabular}{lccr|} 
Suporte & aos & empregados & em \\
decisões & relevantes, & tratar & os \\
empregados como & indivíduos & com \\
vida & pessoal, apoiar & 0 \\
desenvolvimento profissional &
\end{tabular} & $6,10,18,24,31$ e 32 \\
\hline
\end{tabular}

Quadro 2 - Caracteres de identificação de satisfação no trabalho

Fonte: The Great Place to Work Institute (PEREIRA, 2003, p.23).

A tabela a seguir, afere o grau de satisfação dos colaboradores no quesito apropriação. Essa variável adotada pelo modelo GPTWI, é um dos tópicos propostos no modelo de Kozlowski (1989) e também no modelo de Litwin e Stringer, que representa o sentimento dos membros da organização a respeito da sua autonomia nas decisões relacionadas ao seu trabalho. Leva em consideração se a supervisão que recebem é do tipo mais geral, ou seja, o sentimento de ser seu próprio chefe segundo Pereira (2003, p.24-25).

\begin{tabular}{|c|c|c|}
\hline \multirow[t]{2}{*}{ Apropriação } & Lakeside & Metropolitan \\
\hline & $\%$ & $\%$ \\
\hline Discordo totalmente & 4 & 3 \\
\hline Discordo parcialmente & 4 & 0 \\
\hline Indiferente & 3 & 3 \\
\hline Concordo parcialmente & 32 & 58 \\
\hline Concordo totalmente & 57 & 36 \\
\hline Totais & 100 & 100 \\
\hline
\end{tabular}

Tabela 6 - Grau de satisfação: Apropriação

Fonte: Pesquisa direta

Com relação ao sentimento de apropriação, cujas afirmativas 8, 16, 21, 27, 29 e 34 do questionário avaliativo, se referem à satisfação do colaborador sobre sua percepção de responsabilidade por suas ações, ficou constatado ao somar as respostas concordantes que $89 \%$ dos respondentes do Lakeside demonstraram satisfação com esse quesito e $94 \%$ no Metropolitan.

A tabela 7, a seguir, afere o grau de satisfação dos colaboradores no quesito camaradagem, ou seja, o companheirismo dispensado pelos colegas de trabalho. Essa variável adotada pelo modelo GPTWI, também pode ser encontrada no modelo proposto por Kozlowski (1989), entretanto, sob o título "trabalho em equipe" e no 
modelo de Sbragia (1983) sob o título "cooperação existente". No mesmo sentido, o modelo de Litwin e Stringer sugere que camaradagem é o sentimento dos membros da organização sobre a existência de um espírito de ajuda tanto por parte das lideranças quanto dos demais colegas (PEREIRA, 2003, p.24-25).

\begin{tabular}{|c|c|c|}
\hline \multirow[t]{2}{*}{ Camaradagem } & Lakeside & Metropolitan \\
\hline & $\%$ & $\%$ \\
\hline Discordo totalmente & 2 & 0 \\
\hline Discordo parcialmente & 12 & 11,11 \\
\hline Indiferente & 2 & 22,22 \\
\hline Concordo parcialmente & 41 & 33,33 \\
\hline Concordo totalmente & 43 & 33,33 \\
\hline Totais & 100 & 100 \\
\hline
\end{tabular}

Tabela 7 - Grau de satisfação: Camaradagem

Fonte: Pesquisa direta

A variável camaradagem, segundo Pereira (2003), se refere à qualidade da hospitalidade, intimidade e comunidade no ambiente de trabalho, bem como o senso de equipe desenvolvido pelo grupo.

As respostas discordantes sobre o quesito camaradagem somaram $14 \%$ no Lakeside contra $11,11 \%$ no Metropolitan e os respondentes que demonstraram estar indiferentes a essa questão totalizam $2 \%$ no Lakeside contra $22,22 \%$ no Metropolitan. Contudo, dos entrevistados que responderam as afirmativas 5, 14 e 25, $66,66 \%$ da equipe do Metropolitan concordaram com as afirmativas que sugerem satisfação, ficando evidenciado que, assim como na equipe do Lakeside, a equipe do Metropolitan também se mostrou satisfeita no aspecto camaradagem, conforme a tabela 7.

Quanto ao quesito credibilidade, verificado pelas afirmativas 2, 3, 4, 7, 13, 22, 28 e 30, cuja abordagem afere satisfação no grau de acesso e abertura nas comunicações, competência em coordenar os recursos humanos e materiais, assim como integridade e consistência das decisões.

\begin{tabular}{|c|c|c|}
\hline \multirow[t]{2}{*}{ Credibilidade } & Lakeside & Metropolitan \\
\hline & $\%$ & $\%$ \\
\hline Discordo totalmente & 6 & 4 \\
\hline Discordo parcialmente & 5 & 6 \\
\hline Indiferente & 6 & 19 \\
\hline Concordo parcialmente & 39 & 38 \\
\hline Concordo totalmente & 44 & 33 \\
\hline Totais & 100 & 100 \\
\hline
\end{tabular}

Tabela 8 - Grau de satisfação: Credibilidade

Fonte: Pesquisa direta 
Os resultados sobre credibilidade somaram 71\% no Metropolitan contra $83 \%$ no Lakeside, indicando, alto índice de satisfação entre os colaboradores dos dois hotéis, conforme tabela 8.

As afirmativas de número 1, 19, 20 e 33 aludem ao caractere Imparcialidade, referente à eqüidade, ou seja, tratamento equilibrado para todos em termos de recompensas, bem como ausência de favoritismo em recrutamento e promoção, não discriminação e possibilidade de apelação por parte do colaborador.

\begin{tabular}{l|c|c}
\hline \multirow{1}{*}{ Imparcialidade } & Lakeside & Metropolitan \\
\cline { 2 - 3 } & $\%$ & $\%$ \\
\hline Discordo totalmente & 4 & 0 \\
\hline Discordo parcialmente & 10 & 8 \\
\hline Indiferente & 6 & 13 \\
\hline Concordo parcialmente & 31 & 29 \\
\hline Concordo totalmente & 49 & 50 \\
\hline & 100 & 100 \\
\hline
\end{tabular}

Tabela 9 - Grau de satisfação: Imparcialidade

Fonte: Pesquisa direta

No aspecto imparcialidade, foi constatado mesmo nível de satisfação nas duas equipes, haja vista que no Metropolitan os respondentes concordantes somaram $79 \%$ contra $80 \%$ no Lakeside, evidenciando assim, equidade de satisfação nesse quesito.

O próximo caractere avaliado pelas questões de número $9,11,12,15,17$, 23 e 26 foi o Orgulho, referindo-se ao prazer no trabalho realizado pelo indivíduo, no resultado alcançado por um membro ou pelo grupo, bem como nos produtos e serviços oferecidos pela empresa.

\begin{tabular}{|c|c|c|}
\hline \multirow[t]{2}{*}{ Orgulho } & Lakeside & Metropolitan \\
\hline & $\%$ & $\%$ \\
\hline Discordo totalmente & 4 & 5 \\
\hline Discordo parcialmente & 5 & 7 \\
\hline Indiferente & 3 & 7 \\
\hline Concordo parcialmente & 40 & 45 \\
\hline Concordo totalmente & 48 & 36 \\
\hline Totais & 100 & 100 \\
\hline
\end{tabular}

Tabela 10 - Grau de satisfação: Orgulho

Fonte: Pesquisa direta

Sobre o aspecto orgulho, constatou-se índice de satisfação próximo entre as duas equipes dos dois hotéis, ficando a equipe do Metropolitan com $81 \%$ de satisfação contra $88 \%$ de satisfação nas respostas concordantes da equipe do 
Lakeside e apenas 9\% nas respostas discordantes. O índice de indiferença sobre esse aspecto ficou na casa de 3\% no Lakeside, contra 7\% no Metropolitan, conforme ilustra a tabela a seguir.

O último caractere avaliado e ilustrado no gráfico a seguir, se refere ao Respeito, indicando a satisfação dos respondentes quanto ao suporte oferecido aos empregados em decisões relevantes, o tratamento dispensando aos colaboradores como indivíduos com vida pessoal e o apoio no desenvolvimento profissional.

\begin{tabular}{|c|c|c|}
\hline \multirow[t]{2}{*}{ Respeito } & Lakeside & Metropolitan \\
\hline & $\%$ & $\%$ \\
\hline Discordo totalmente & 6 & 0 \\
\hline Discordo parcialmente & 8 & 3 \\
\hline Indiferente & 4 & 8 \\
\hline Concordo parcialmente & 31 & 44 \\
\hline Concordo totalmente & 51 & 44 \\
\hline Totais & 100 & 100 \\
\hline
\end{tabular}

Tabela 11 - Grau de satisfação: Respeito

Fonte: Pesquisa direta

No aspecto respeito registrou-se $88 \%$ de satisfação por parte da equipe do Metropolitan contra $82 \%$ da equipe do Lakeside, representando elevado índice de satisfação nas duas equipes.

De acordo com Pereira (2003) o modelo de Litwin e Stringer também prevê a qualidade das relações entre os membros do grupo sob o título "relações" que é a percepção dos membros da organização acerca da existência de um ambiente de trabalho gratificante e de boas relações sociais, tanto entre os pares quanto entre chefe e subordinados.

Com base nas seis variáveis propostas pelo GPTWI, que determinam o clima organizacional de uma empresa, elaborou-se uma tabela com a média geral dos resultados obtidos nos dois hotéis pesquisados, sendo que as perguntas discordantes revelam insatisfação e as perguntas concordantes indicam a satisfação dos colaboradores. 


\begin{tabular}{|c|c|c|}
\hline \multirow[t]{2}{*}{ Clima organizacional } & Lakeside & Metropolitan \\
\hline & $\%$ & $\%$ \\
\hline Discordo totalmente & 4 & 2 \\
\hline Discordo parcialmente & 7 & 6 \\
\hline Indiferente & 4 & 12 \\
\hline Concordo parcialmente & 36 & 41 \\
\hline Concordo totalmente & 49 & 39 \\
\hline Totais & 100 & 100 \\
\hline
\end{tabular}

Tabela 12 - Indicadores de clima organizacional nos dois hotéis Fonte: Pesquisa direta

Os resultados apurados tanto no Lakeside quanto no Metropolitan apontam bom nível de clima organizacional. Entre os dois hotéis pesquisados, o clima organizacional do Lakeside se mostrou em melhor qualidade em relação ao Metropolitan Flat, haja vista que $85 \%$ dos respondentes da equipe Lakeside optaram pelas opções concordantes às afirmativas que aludem às condições ideais nos fatores que interferem no clima organizacional, contra $80 \%$ dos respondentes da equipe Metroplitan. Em uma escala de 0 a 100, pode-se dizer que 85 e 80 representam médias muito boas em termos de satisfação geral dos colaboradores.

Dessa forma, constatou-se que os resultados obtidos indicam níveis de clima organizacional muito semelhante entre as duas equipes, conforme se pode observar na tabela 12, restando comparar tais dados com os índices de satisfação dos clientes dos dois hotéis e, assim, poder constatar se há indícios ou não na relação entre o clima organizacional e a qualidade no atendimento, conforme propõe o objetivo do presente trabalho.

6.3 Índice de satisfação dos clientes

A Atlantica Hotels realiza avaliação de satisfação de seus clientes por meio de sistema informatizado, disponibilizado via internet, que se serve do Programa Market Metrix onde o cliente responde, em alguns minutos, sobre suas percepções com relação aos serviços e produtos utilizados durante o período em que ficou hospedado em uma das unidades administradas pela Rede.

O sistema foi implantado a partir de junho de 2006 e tem demonstrado eficácia na avaliação pretendida, oferecendo subsídios para a realização dos 
treinamentos com funcionários e até mesmo modificações em suas estruturas, visando sempre atender as expectativas de seu público-alvo. O sistema de score utilizado na plataforma Market Metrix vai de 50 a 90 pontos, e faz uma comparação instantânea com a média de toda rede.

Com relação à satisfação geral do cliente, com base na média simples referente ao mês de março/2007, o Lakeside alcançou o score 73,43 , enquanto o Metropolitan alcançou o score 71,4, conforme demonstra a tabela a seguir:

\begin{tabular}{l|c|c}
\hline \multirow{1}{*}{\multicolumn{1}{c|}{ Itens avaliados }} & Lakeside & Metropolitan \\
\cline { 2 - 3 } & score & score \\
\hline Atmosfera atrativa e agradável & 70 & 74 \\
\hline Serviço eficiente e amigável & 72 & 78 \\
\hline Avaliação geral do restaurante & 73 & 58 \\
\hline Apresentação da comida & 74 & 63 \\
\hline Qualidade da comida & 70 & 58 \\
\hline Variedade de opções & 68 & 47 \\
\hline Limpeza e aparência das áreas comuns & 68 & 80 \\
\hline Eficiência do chek-in & 75 & 84 \\
\hline Amabilidade do agente de reservas & 78 & 85 \\
\hline Serviços gerais e acessibilidade & 67 & 72 \\
\hline Qualidade do atendimento telef & 75 & 60 \\
\hline Amabilidade e atitude & 80 & 83 \\
\hline Conhecimento do hotel & 74 & 73 \\
\hline Avaliação geral da receptividade & $\mathbf{7 7}$ & 78 \\
\hline Cordialidade & $\mathbf{7 8}$ & 72 \\
\hline Disposição & $\mathbf{7 6}$ & $\mathbf{7 8}$ \\
\hline
\end{tabular}

Tabela 13 - Indicadores de satisfação do cliente

Fonte: Atlantica Hotels: Dados referente mar/2007

Para efeito de relacionar a qualidade do clima organizacional com a satisfação do cliente, separou-se os quesitos avaliados em duas tabelas distintas, sendo a primeira tabela com os itens que não exigem a interação direta do colaborador com o cliente e a segunda tabela contendo os itens que exigem a interação do colaborador com o cliente. O objetivo desta distinção de itens é para verificar se há registro de alteração na percepção da qualidade dos serviços por parte do cliente em ambos os casos.

Dessa forma, observa-se na tabela 14, a seguir, os seguintes resultados: 


\begin{tabular}{l|c|c}
\hline \multicolumn{1}{c|}{ Itens avaliados } & Lakeside & Metropolitan \\
\cline { 2 - 3 } & score & score \\
\hline Avaliação geral do restaurante & 73 & 58 \\
\hline Apresentação da comida & 74 & 63 \\
\hline Qualidade da comida & 70 & 58 \\
\hline Variedade de opções & 68 & $\mathbf{8 7}$ \\
\hline Limpeza e aparência das áreas comuns & 68 & 72 \\
\hline Serviços gerais e acessibilidade & 67 & 73 \\
\hline Conhecimento do hotel & 74 & $\mathbf{6 4 , 4 2}$ \\
\hline
\end{tabular}

Tabela 14 - Indicadores de satisfação do cliente em itens que não exigem interação direta com o cliente

Fonte: Atlantica Hotels: Dados referente mar/2007

O programa Market Matrix utilizado pela Rede Atlantica para avaliação de satisfação de seus clientes avalia de forma geral os serviços prestados, a qualidade no atendimento ao cliente, bem como os aspectos mais importantes na rotina de hospedagem. Entretanto, para o presente trabalho, considerou-se 0 ato de atendimento ao cliente as atividades que requerem a interação direta entre colaboradores e hóspedes, preterindo as atividades descritas na tabela $14 \mathrm{e}$ privilegiando as atividades descritas na tabela 15, pois, para efeito de checar a influência da disposição pessoal do colaborador no momento em que interage com o cliente se faz necessária tal distinção.

Para Ferreira (1993, p. 53) atender indica: 1) dar ou prestar atenção; 2) atentar, observar; 3) acolher com atenção ou cortesia. Neste sentido, o ato do atendimento exige a interação direta entre colaborador e cliente.

Segundo Kotler (1998), a satisfação para o cliente depende do que ele percebe em relação ao desempenho dos prestadores de serviços em relação às suas expectativas. Nesse sentido, o atendimento requer, necessariamente, o contato direto entre o colaborador que presta um serviço e o cliente, pois a percepção do cliente sobre a qualidade desse contato direto irá determinar o grau de satisfação do cliente e, consequentemente, a qualidade geral do atendimento recebido.

Dentre os aspectos de atendimento da rotina diária dos hotéis Lakeside e Metropolitan, destacaram-se aquelas atividades que exigem a interação direta entre colaborador e cliente, no intuito de comparar a percepção dos hóspedes em relação à disposição pessoal dos colaboradores dos dois hotéis. Parte-se da premissa que a disposição pessoal dos colaboradores é uma conseqüência do clima organizacional e quanto melhor for o clima organizacional, melhor será a disposição pessoal dos 
colaboradores, influenciando a forma como o cliente percebe 0 atendimento recebido.

Assim, apresentam-se os scores de satisfação do cliente nas atividades que requerem interação direta entre colaborador e cliente:

\begin{tabular}{l|c|c}
\hline \multirow{1}{*}{ Itens avaliados } & Lakeside & Metropolitan \\
\cline { 2 - 3 } & score & score \\
\hline Atmosfera atrativa e agradável & 70 & 74 \\
\hline Serviço eficiente e amigável & 72 & 78 \\
\hline Eficiência do chek-in & 75 & 84 \\
\hline Amabilidade do agente de reservas & 78 & 85 \\
\hline Qualidade do atendimento telefônico & 75 & 60 \\
\hline Amabilidade e atitude & 80 & 83 \\
\hline Avaliação geral da receptividade & 77 & 78 \\
\hline Cordialidade & 78 & 72 \\
\hline Disposição & 76 & 78 \\
\hline \multicolumn{1}{c|}{ Média geral } & $\mathbf{7 5 , 6 6}$ & $\mathbf{7 6 , 8 8}$ \\
\hline
\end{tabular}

Tabela 15 - Indicadores de satisfação do cliente em itens que exigem interação direta com o cliente

Fonte: Atlantica Hotels: Dados referente mar/2007

Comparando os resultados contidos nas tabelas 14 e 15 percebe-se que houve na segunda tabela um aumento significativo no score que mede a satisfação do cliente em relação ao atendimento recebido em ambos os hotéis. Portanto, presume-se que a qualidade do atendimento recebido pelo cliente nas atividades que requerem interação direta, sofre uma variação positiva, enquanto que nos quesitos que dispensam a interação do cliente com o colaborador, a variação é negativa e o índice de satisfação tende a diminuir.

Esse resultado indica a possibilidade de interferência do clima organizacional sobre a disposição pessoal do colaborador e, consequentemente, o impacto dessa disposição sobre a percepção do cliente em relação à qualidade do atendimento recebido.

Segundo o Sebrae (2007, p.1), a manutenção de um padrão elevado de qualidade na prestação de um determinado serviço depende da satisfação dos funcionários que lidam diretamente com os clientes. "[...] as empresas de serviços excelentemente administradas acreditam que as relações com os funcionários refletirão sobre as relações com os consumidores".

Para Juran (1990) a empresa que quer agradar seus clientes precisa zelar pela motivação de seus funcionários. 
Neste sentido, Lopes (1980, p.23), Ribeiro (1994, p.32) e Chiavenato (1991, p.33) defendem que a motivação está intrinsecamente relacionada com "sentimentos de realização e de reconhecimento profissional", interferindo na psicodinâmica interna da pessoa. Tais sentimentos estão contidos no rol de variáveis que compõem o clima organizacional de uma empresa.

Portanto, ao constatar indícios de influência do clima organizacional sobre a qualidade do atendimento, confirma-se a importância do clima organizacional como facilitador no processo de excelência no atendimento, devendo as empresas dedicar esforços para promover o melhor clima organizacional possível, com vistas à satisfação de seus clientes. 


\section{CONSIDERAÇÕES FINAIS}

O presente trabalho teve como objetivo analisar a relação da qualidade do clima organizacional e a qualidade do atendimento oferecido pelos colaboradores nos hotéis pesquisados. Embora possa parecer óbvia essa relação, nem sempre a ambiência do trabalho é responsável exclusivamente pela satisfação do cliente. Entretanto, ao se analisar o clima organizacional dos hotéis Lakeside e Metropolitan Flat, pôde-se pressupor que a harmonia entre os caracteres que resultam no clima organizacional satisfatório é importante para a satisfação geral do cliente.

Com base nas principais teorias sobre o turismo e sua evolução histórica no mundo, buscou-se compreender a demanda do mercado de hospitalidade e, assim, reunir importantes conceitos sobre gestão estratégica com foco no atendimento ao cliente, pois este fator contribui para a competitividade entre empresas concorrentes, determinando a preferência do cliente.

Os autores citados no capítulo 3 revelam em suas respectivas obras que a qualidade no atendimento ao cliente depende em parte da disposição dos colaboradores que interagem com esses clientes. Assim, buscou-se estudar no referencial teórico sobre clima organizacional e atendimento ao cliente, uma correlação entre estes dois fatores. Para testar a teoria, foram descritos os serviços e a infra-estrutura dos hotéis estudados, no intuito de efetivar pesquisa de campo e assim poder comparar as teorias citadas com os resultados obtidos, deduzindo hipoteticamente que o clima organizacional exerce certa influência sobre a qualidade no atendimento.

O desafio, portanto, foi estudar a relação direta entre a satisfação dos clientes como reflexo da satisfação dos colaboradores. Tal fator pode indicar uma correlação interessante de caracteres motivacionais, na busca pela excelência no atendimento. $O$ fator Orgulho alcançou o segundo lugar de satisfação entre os respondentes tendo alcançado $88 \%$ dos respondentes nas afirmativas concordantes.

Assim, com base nas principais teorias sobre clima organizacional pôde-se aplicar pesquisa de avaliação de clima organizacional, em um grupo representativo de colaboradores do Quality Resort Lakeside e Metropolitan Flat, cuja amostragem correspondeu a $31 \%$ do total de funcionários lotados em cada hotel pesquisado. 
De acordo com a pesquisa realizada, pôde-se constatar, somando os itens concordantes, que $85 \%$ dos respondentes do Lakeside estão satisfeitos com todos os caracteres necessários ao clima organizacional satisfatório, contra $80 \%$, utilizando os mesmos critérios no Metropolitan, indicando leve vantagem no clima organizacional do Lakeside em relação ao Metropolitan.

Reportando às principais teorias de clima organizacional estudadas neste trabalho, conclui-se que a harmonia dos caracteres que constituem o clima organizacional dos hotéis Lakeside e Metropolitan, por si só não poderia ser responsável pelo alto índice de satisfação dos clientes. Contudo, a ênfase no senso de apropriação e o orgulho de se trabalhar nos hotéis, potencializam significativamente os resultados obtidos, quando se compara esses resultados aos índices de satisfação do cliente quando os quesitos avaliados indicam interação direta com os funcionários, eleva-se o score de satisfação, se comparados com os quesitos que não exigem a interação direta com os funcionários, conforme demonstrados nas tabelas de resultados.

Para efeito de comparação, projetou-se no hotel Metropolitan a mesma pesquisa realiza no Lakeside, cujo objetivo foi verificar a reincidência dos aspectos do clima organizacional sobre a qualidade no atendimento. Os resultados obtidos no hotel Metropolitan indicaram equivalência com os resultados do Lakeside, inclusive com relação ao índice de satisfação dos clientes nas atividades que exigem interação entre os colaboradores e clientes.

Dessa forma, deduz-se que o clima organizacional exerce certa influência na satisfação geral do cliente, devendo, portanto, serem observados os caracteres apropriação, camaradagem, credibilidade, imparcialidade, orgulho e respeito como fatores de motivação da equipe e, por conseqüência, elementos de importância significativa na manutenção do clima organizacional da empresa como forma de se promover a qualidade no atendimento ao cliente. Contudo, devido à leve vantagem do clima organizacional do Lakeside sobre o Metropolitan, sugere-se à administração do Metropolitan certa atenção nos quesitos camaradagem, credibilidade e imparcialidade que foram os quesitos que obtiveram o maior índice de insatisfação por parte dos colaboradores, apesar de satisfatórios. Acredita-se que dessa forma, a administração do hotel Metropolitan possa aprimorar ainda mais a satisfação de seus colaboradores e, assim, alcançar melhores resultados. 


\section{REFERÊNCIAS}

ABBEY, A. \& DICKSON, J.W. R\&D work climate and innovation in semiconductors. Academy of Management Journal, v.26, n.2, p.362-368, 1983. In: LIMA, Wander Demonel de. Pesquisa de clima organizacional como ferramenta estratégica de gestão da qualidade de vida no trabalho. São Paulo, Unifei, 2004.

ALLPORT, G.W. Personalidade. São Paulo: Herder, 1966.

ALVES, J. Liderança e clima organizacional. Revista de Psicología del deporte, 9, 1-2, 123-133, 2000. Disponível em: <http://193.137.95.65/Conteudos/Avalia $\%$ C3\%A7\%C3\%A30\%20II/clima\%20lideran\%C3\%A7a.pdf>. Acesso em: 16 fev. 2007.

ANDRADE, José Vicente de. Turismo: fundamentos e dimensões. 8. ed. São Paulo: Ática, 2000.

ANSARAH, Marilia Gomes dos Reis (Org.). Turismo: Segmentação de Mercado. São Paulo: Futura, 1999.

BADARÓ, Rui Aurélio de Lacerda. O Direito do Turismo através da história e sua evolução. São Paulo: [s.n.], 2007. Disponível em: <www.ibcdtur.org.br/arquivos/DireitoDoTurismoHist.pdf>. Acesso em: 4 ago. 2007.

BAHL, Miguel (Org.). Turismo com Responsabilidade Social. São Paulo: Roca, 2004.

BARROS, Aidil J. da Silveira; LEHFELD, Neide Aparecida de Souza. Fundamentos de metodologia: um guia para a iniciação científica. 2. ed. São Paulo: Makroon Books, 2000.

BEDANI, Marcelo. Clima organizacional: mensuração, investigação e diagnóstico. São Paulo: UnB, 2006. Disponível em: <http://psicolatina.org/Siete/clima.html>. Acesso em: 17 set. 2006.

BEKIN, Saul Faingaus. Endomarketing: como praticá-lo com sucesso. São Paulo: Prentice Hall, 2004.

BENI, Mário Carlos. Análise Estrutural do Turismo. 2. ed. São Paulo: Editora

BERGAMINI, Cecília Whitaker. Motivação nas Organizações. 4. ed. São Paulo: Atlas, 1997.

BOSS, Medard. Angústia, Culpa e Libertação. 2. ed. São Paulo; Duas Cidades, 1997.

BRESCANCINI, Ana Maria. Insatisfeito, Satisfeito, Motivado. São Paulo: Governo do Estado de São Paulo, 2006. Revista Fundep, Vers. Elet. Artigo. Disponível em: <http://www.revista.fundap.sp.gov.br/revista2/paginas/ ferramentas.htm>. Acesso em 25 fev. 2007. 
CAMPOS, José Ruy Veloso (Org.). Estudo de viabilidade para projeto hoteleiro. Campinas: Papirus, 2003.

CARVALHO, Caio Luiz de et al. Destino Brasil. Rio de Janeiro, Hamburg, 1994.

CASTELLI, Geraldo. Administração Hoteleira. 8. ed. Caxias do Sul: Educs, 2001.

CASTRO, Sidnei Teixeira de. A hospitalidade e a qualidade total no Turismo. Rio de Janeiro: UERJ/Sipec, 2001.

CHIAVENATO, L. Administração de Recursos Humanos. São Paulo: Atlas, 1991.

CORIOLANO, Luzia Neide M. T. Do local ao global: O turismo litorâneo cearense. Campinas: Papirus, 1998.

CRUZ, Rita de Cassia A. Política de turismo e território. São Paulo: Contexto, 2000.

DIAS, Célia Maria de Moraes (Org.). Hospitalidade: Reflexões e perspectivas. São Paulo: Manole, 2002.

DENCKER. Ada. Métodos e Técnicas de pesquisa em Turismo. São Paulo: Futura, 2004

EMBRATUR. Disponível em: <www.turismo.gov.br>. Acesso em 8 fev. 2007.

FERREIRA, Aurélio Buarque de Holanda. Minidicionário da língua portuguesa. Rio de Janeiro: Nova Fronteira, 1993.

FOREHAND, G. A., GILMER, H. B. Environmental variation in studies of organizational behavior. Psychological Bulletin. v. 62, n. 6, p. 361-382, 1964. In: PALACIOS, Kátia Puentes. Clima social da organização. Brasília: Cecap, 2006.

GPTW, Great Place to Work Institute. Melhores empresas para se trabalhar no Brasil. Disponível em: <http://www.gptw.com.br/ melhoresbrasil/historico.html>. Acesso em: 11 mar. 2007.

GUIMARÃES, Paulo Ferraz. Novo Ciclo de Investimentos e Inovações Tecnológicas no Setor de Turismo no Nordeste. Fortaleza: BNB/ETENE, 1999.

HAZIN, Ana; OLIVEIRA, Cleide; MEDEIROS, Rejane. Turismo e mão-de-obra: entre o real e o ideal. Recife: Fundação Joaquim Nabuco / Universidade Católica de Pernambuco, 2001.

IBGE. Brasil em números 2004. Disponível em: <http://www1.ibge.gov.br/ibgeteen /datas/turismo/numeros.html>. Acesso em 27 fev. 2007.

JURAN, J. M. Planejando para a qualidade. São Paulo: Pioneira, 1990.

KOTLER, Philip. Administração de marketing: análise, planejamento, implementação e controle. 8. ed. São Paulo: Atlas, 1998. 
Hall do Brasil, 1998b.

LAGE, Beatriz Helena Gelas. Economia do Turismo. Campinas, SP: Papirus, 1991.

LEMOS, Leandro de. Turismo: Que negócio é este? Campinas: Papirus, 1999.

LOPES, Tomás de Vilanova Monteiro. Motivação no Trabalho. São Paulo: Fundação Getúlio Vargas, 1980.

LUZ, Ricardo Silveira. A qualidade do atendimento e o clima organizacional. RH em Síntese, n.10, mai/jun, ano II, 1996. Disponível em: <http://gestaoerh.com.br/site/ visitante/artigos/gead_011.php>. Acesso em: 25 fev. 2007.

MARCONI, M.; LAKATOS, E. Fundamentos da metodologia científica. São Paulo: Atlas, 2001.

MARTIN, Vanesa. Manual Prático de Eventos. São Paulo: Atlas, 2003.

MAXIMIANO, Antônio C.A. Da escola científica à competitividade na economia globalizada. 2. ed. São Paulo: Atlas, 2000.

MCKENNA, Regis. Marketing de relacionamento: estratégias bem-sucedidas para a era do cliente. Rio de Janeiro: Elsevier, 1997.

MENEZES, Eduardo Frigoletto de. Evolução histórica do turismo. Disponível em: <http://www.frigoletto.com.br/GeoTur/evol.htm>. Acesso em 19 fev. 2007.

MOLINA, Sergio. Modernización de empresas turísticas: Un enfoque para el logro de la calidad total. México: Editorial Diana, 1994.

. El Pós Turismo: de los centros turísticos industriales a las ludópolis. México: MOLINA, 1998. In: Revista Turismo. Disponível em: <www.revistaturismo. com.br>. Acesso em: 22 mar. 2007.

OMT. Disponível em: <http://www.world-tourism.org/facts/eng/economy.htm>. Acesso em: 20 mar. 2007.

PADILLA, Oscar de la Torre. El turismo: fenómeno social. 2 $2^{\mathrm{a}}$ ed., México: Fondo de Cultura Económica, 1997.

PALACIOS, Kátia Puentes. Clima social da organização. Brasília: Cecap, 2006.

PARANHOS, Moacyr. Gestão da Produção. Apostila. Curitiba: Ibpex, 2006.

PEREIRA, Luiz Alberto. Poder e clima organizacional: um estudo de caso em uma empresa petroquímica. 2003 (tese), Salvador: UFB. Disponível em: <http://www. adm.ufba.br/PoderClimaOrganizacional2.pdf>. Acesso em: 9 fev. 2007.

PIETRI JR., P.H; MOSLEY, D.C; MEGGINSON, L.C. Administração: Conceitos e aplicações. 4. ed. São Paulo: Harba, 1998.

PROGESTÃO CONSULTING. Desmistificando Produtividade. Disponível em: $<$ http://www.progestao.com.br/produtividade.htm>. Acesso em 26 jan. 2007. 
REVISTA TURISMO. Disponível em: <www.revistaturismo.com.br>. Acesso em: 22 mar. 2007.

RIBEIRO, Dr. Lair. Auto-Estima. 3.ed. Rio de Janeiro: Objetiva, 1994.

ROBINSON, Mike. Por um turismo consensual. O Correio da UNESCO, pp.22-23, set./out., 1999.

RUSCHMANN, Doris. Turismo e Planejamento Sustentável: a proteção do meio ambiente. Campinas: PAPIRUS, 1997.

SALGADO, Léo. Motivação no trabalho. Rio de Janeiro: Qualitymark, 2005.

SANTOS, Milton. O mundo, o Brasil e a globalização: $O$ horror não dura eternamente. Rumos do Desenvolvimento. oㅜ 137. Rio de Janeiro, jun/1997, pp.410.

SEBRAE. Produtividade. Disponível em: <http://www.sebrae.com.br/br/parasua empresa/produtividade.asp>. Acesso em: 26 jan. 2007.

SEHN, Caroline. A motivação dentro da motivação do grupo Accor: ferramenta de comunicação interna como meio motivacional nas organizações. 2005 (tese), São Paulo: USP, 2005.

SICOLI, Marcelo Caus. Brasil e o turismo: construindo um presente sólido para as futuras gerações, 2005. In: Revista Turismo. Disponível em: <www.revistaturismo. com.br>. Acesso em: 19 mar. 2007.

SILVA, Mary Aparecida Ferreira da. Métodos e técnicas de pesquisa. Curitiba: Ibpex, 2003.

SISTARE, Paul. Atlantica Hotels International. Disponível em: <www.atlanticahotels.com>. Acesso em 4 mar. 2007.

SOARES, Lucila. Revista VEJA, São Paulo, ed. 1.635, p.80-81, 09/02/2000.

TRIGO, Luiz Gonzaga Godoi. Turismo e qualidade. Tendências contemporâneas. Campinas: Papirus, 1993.

VASSALO, Cláudia. Um negócio bom para os dois. Revista Exame. N.18, set, 2004, p. 24-30.

WANTANABE, Sônia. Hospitalidade: uma abordagem para melhoria da qualidade. Disponível em: <http://www.hospitalar.com/opiniao/opiniao_1176.html>. Acesso em: 30. abr 2007.

WILLE, Sorahia Regina. Como viabilizar melhorias no mecado turistico brasileiro. São Paulo: 2007. In: Revista Turismo. Disponível em: <www.revistaturismo. com.br>. Acesso em: 5 ago. 2007. 


\title{
ANEXO I \\ Questionário de Avaliação de Clima Organizacional \\ Quality Resort Lakeside e Metropolitan Flat
}

\author{
Universidade de Brasilia \\ Universidade de Brasília \\ UNIVERSIDADE DE BRASÍLIA - UnB \\ Centro de Excelência em Turismo
}

Prezado[a] Colega,

Esta pesquisa tem por finalidade dar subsídios técnicos à minha monografia para obtenção do título de Especialista no Curso de Pós-Graduação em Gestão De Negócios em Turismo, promovida pela Universidade de Brasília - UnB.

A sua aplicação está direcionada aos funcionários do Quality Resort Lakeside.

As informações serão analisadas desconsiderando-se a identificação dos respondentes, tendo em vista a manutenção do sigilo e do anonimato da pesquisa.

Obrigada por sua colaboração!

Ricardo Caiafa 


\section{Questionário de avaliação de clima organizacional Informações Pessoais}

\begin{tabular}{|c|c|}
\hline Área de atuação & $\begin{array}{l}\text { [ ] Portaria [ ] Recepção [ ] Camareira [ ] Supervisão } \\
\text { [ ] Cozinha [ ] Gerviços gerais [ ] Outro: }\end{array}$ \\
\hline Sexo & Masculino [ \\
\hline Estado civil & $\begin{array}{l}\text { ] Solteiro[a] [ ] Separado[a] ou divorciado[a] [ ] Casado[a] } \\
\text { ] Viúvo[a] [ ] União estável }\end{array}$ \\
\hline Idade & de 16 a 30 anos [ ] de 31 a 45 anos [ ] acima de 45 anos \\
\hline Tempo de serviço & $\begin{array}{l}\text { até } 2 \text { anos } \\
\text { de } 3 \text { a } 5 \text { anos } \\
\text { de } 6 \text { a } 10 \text { anos } \\
\text { acima de } 11 \text { anos }\end{array}$ \\
\hline $\begin{array}{l}\text { Grau de } \\
\text { escolaridade }\end{array}$ & $\begin{array}{l}\text { Ensino Fundamental (antigo } 1^{\circ} \text { Grau) } \\
\text { Ensino Médio (antigo } 2^{\circ} \text { grau) } \\
\text { Ensino Superior incompleto } \\
\text { Ensino Superior completo } \\
\text { Pós-graduação } \\
\text { Outro }\end{array}$ \\
\hline
\end{tabular}

\section{Instruções para o Preenchimento}

1 - Leia cuidadosamente cada questão antes de responder;

2 - Responda cada questão considerando a situação real do seu dia-a-dia de trabalho;

3 - Para responder as questões, marque um "X" na melhor alternativa que represente sua opinião. Sendo:

- Opinião número 1 - Discordo totalmente;

- Opinião número 2 - Discordo parcialmente;

- Opinião número 3 - Indiferente

- Opinião número 4 - Concordo parcialmente;

- Opinião número 5 - Concordo totalmente.

\begin{tabular}{|c|c|c|c|c|c|c|c|c|c|}
\hline \multirow{2}{*}{\multicolumn{2}{|c|}{$\begin{array}{c}\begin{array}{c}\text { Discordo } \\
\text { totalmente }\end{array} \\
1\end{array}$}} & $\begin{array}{c}\text { Discordo } \\
\text { parcialmente }\end{array}$ & Indiferente & \multicolumn{2}{|c|}{$\begin{array}{l}\text { Concordo } \\
\text { parcialmente }\end{array}$} & \multicolumn{4}{|c|}{$\begin{array}{l}\text { Concordo } \\
\text { totalmente }\end{array}$} \\
\hline & & 2 & 3 & 4 & & & & 5 & \\
\hline $\mathbf{N}^{\circ}$ & \multicolumn{4}{|c|}{ Afirmações } & 1 & 2 & 3 & 4 & 5 \\
\hline 1 & \multicolumn{4}{|c|}{$\begin{array}{l}\text { Os trabalhos são distribuídos de forma justa e equilibrada entre } \\
\text { todos os funcionários de um mesmo setor. }\end{array}$} & & & & & \\
\hline 2 & \multicolumn{4}{|c|}{ Meu salário é um atrativo para minha permanência no hotel. } & & & & & \\
\hline 3 & \multicolumn{4}{|c|}{ Tenho possibilidade de progredir salarialmente. } & & & & & \\
\hline 4 & \multicolumn{4}{|c|}{$\begin{array}{l}\text { O hotel oferece benefícios que atendem minhas necessidades e } \\
\text { expectativas. }\end{array}$} & & & & & \\
\hline 5 & \multicolumn{4}{|c|}{$\begin{array}{l}\text { Existe cooperação entre os funcionários dos diversos setores do } \\
\text { hotel. }\end{array}$} & & & & & \\
\hline 6 & \multicolumn{4}{|c|}{ Meu chefe sabe o que faz e conhece bem o seu serviço. } & & & & & \\
\hline 7 & \multicolumn{4}{|c|}{ Meu chefe sempre me fala sobre o que ele pensa do meu trabalho. } & & & & & \\
\hline
\end{tabular}




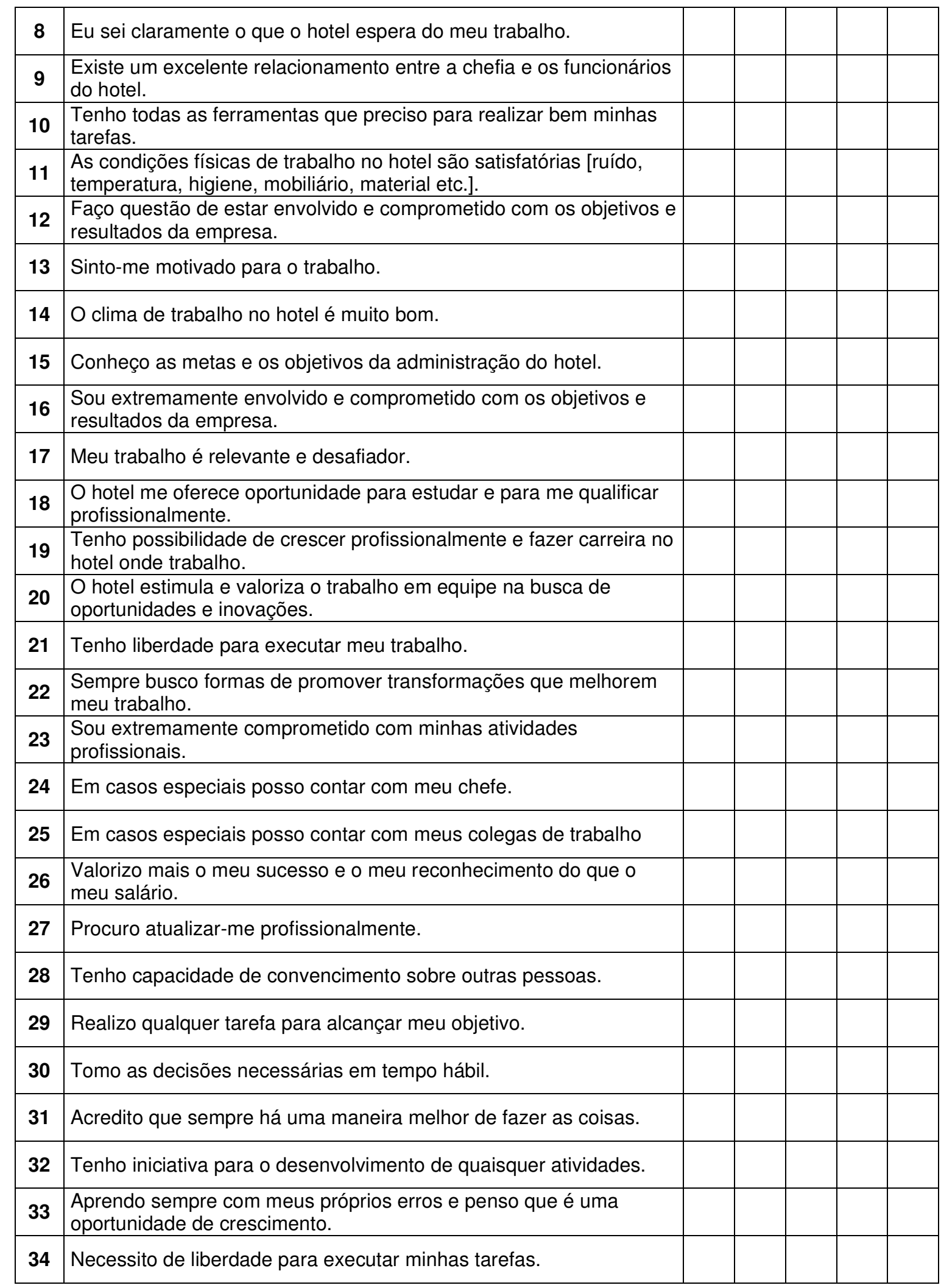




\section{ANEXO II \\ Gráfico de satisfação dos clientes Lakeside e Metropolitan Flat}

A seguir, apresentam-se os índices de satisfação dos clientes do Lakeside e Metropolitan Flat, conforme pesquisa interna, realizada pela administração do hotel.

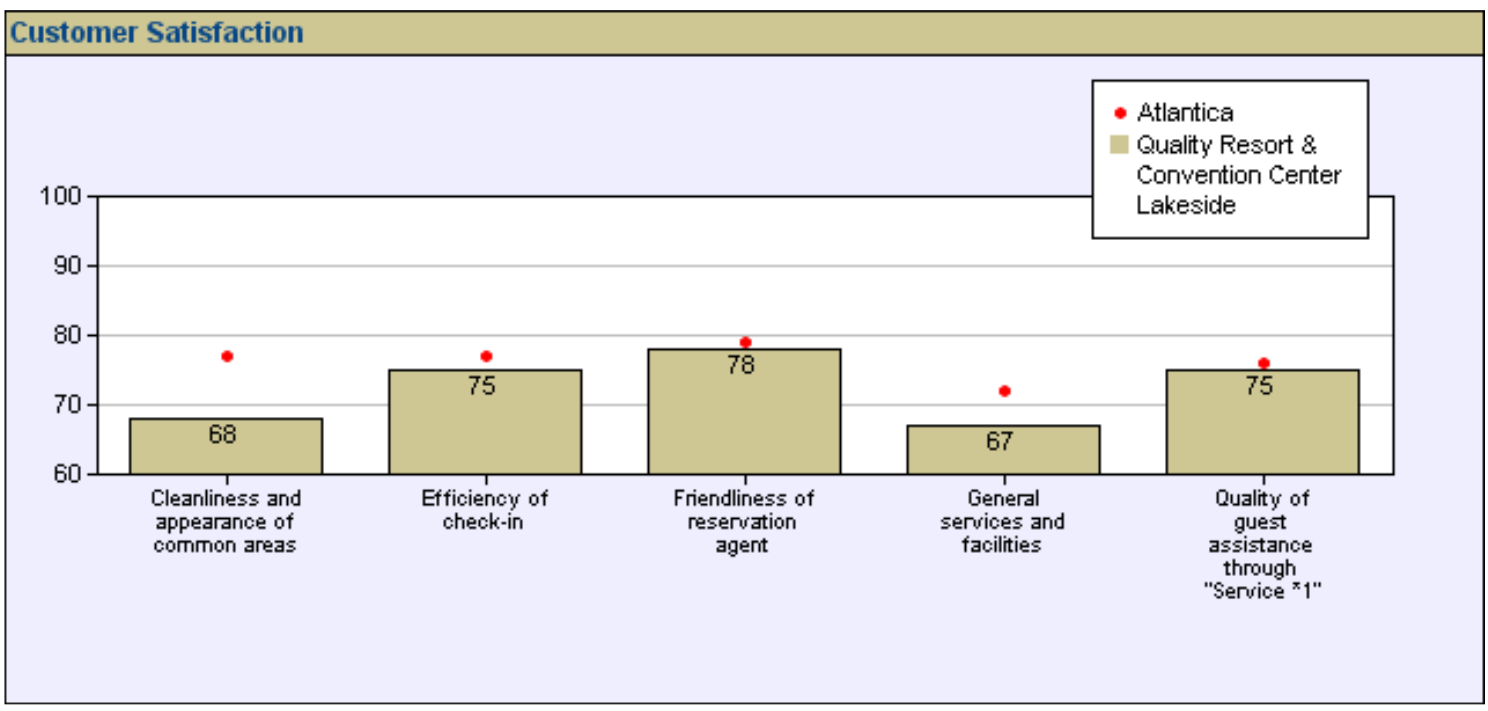

Gráfico 1 - Satisfação do cliente por categoria de serviços / Lakeside.

Fonte: Banco de dados Atlantica Hotel - Market Metrix (mar/2007).

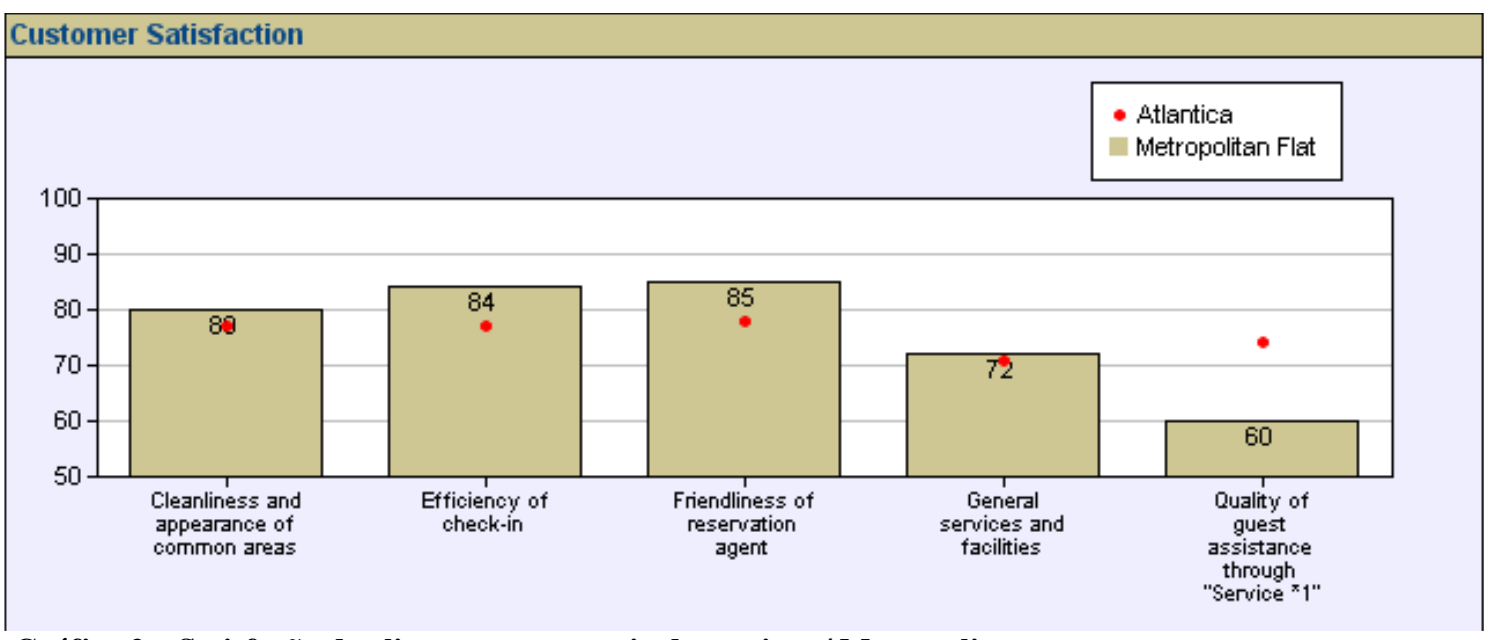

Gráfico 2 - Satisfação do cliente por categoria de serviços / Metropolitan.

Fonte: Banco de dados Atlantica Hotel - Market Metrix (mar/2007). 


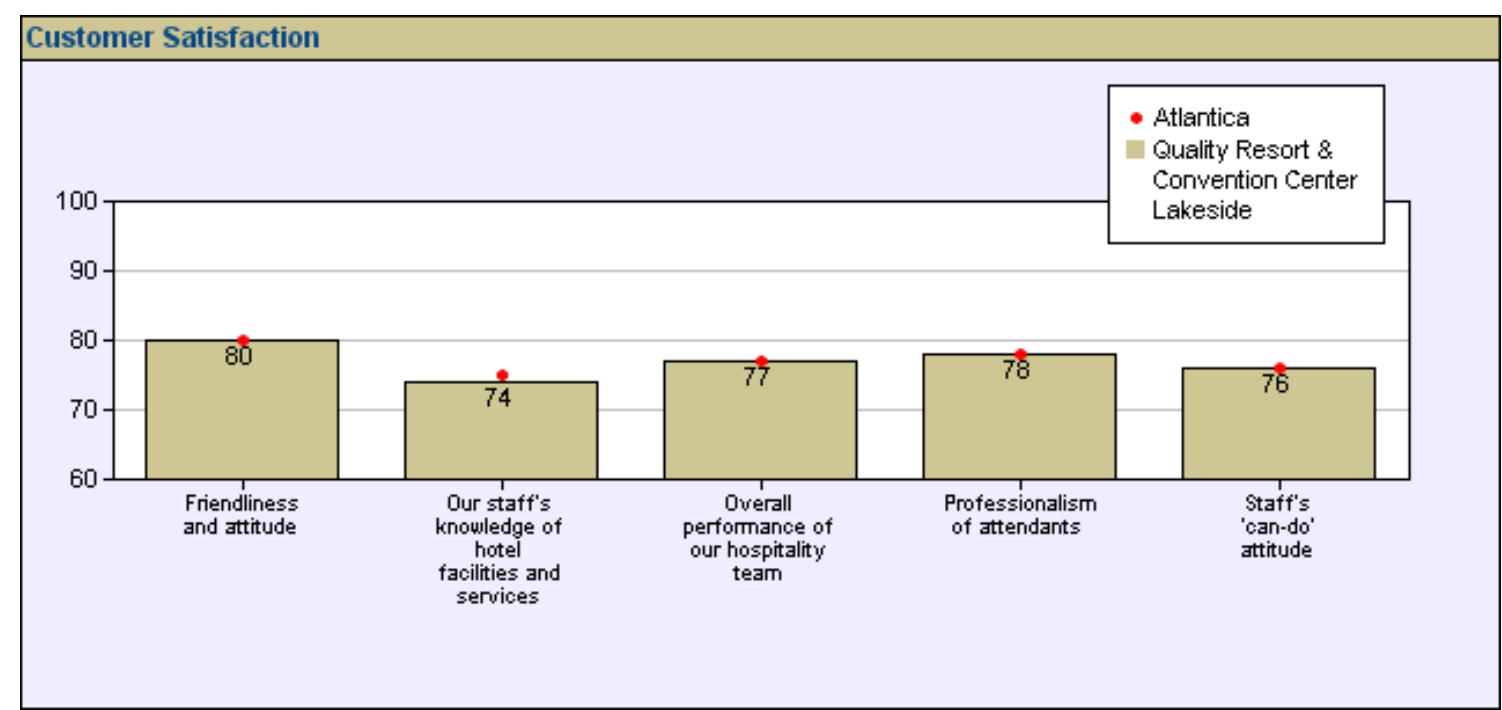

Gráfico 3 - Satisfação do cliente em interação com colaboradores do hotel Lakeside.

Fonte: Banco de dados Atlantica Hotel - Market Metrix (mar/2007).

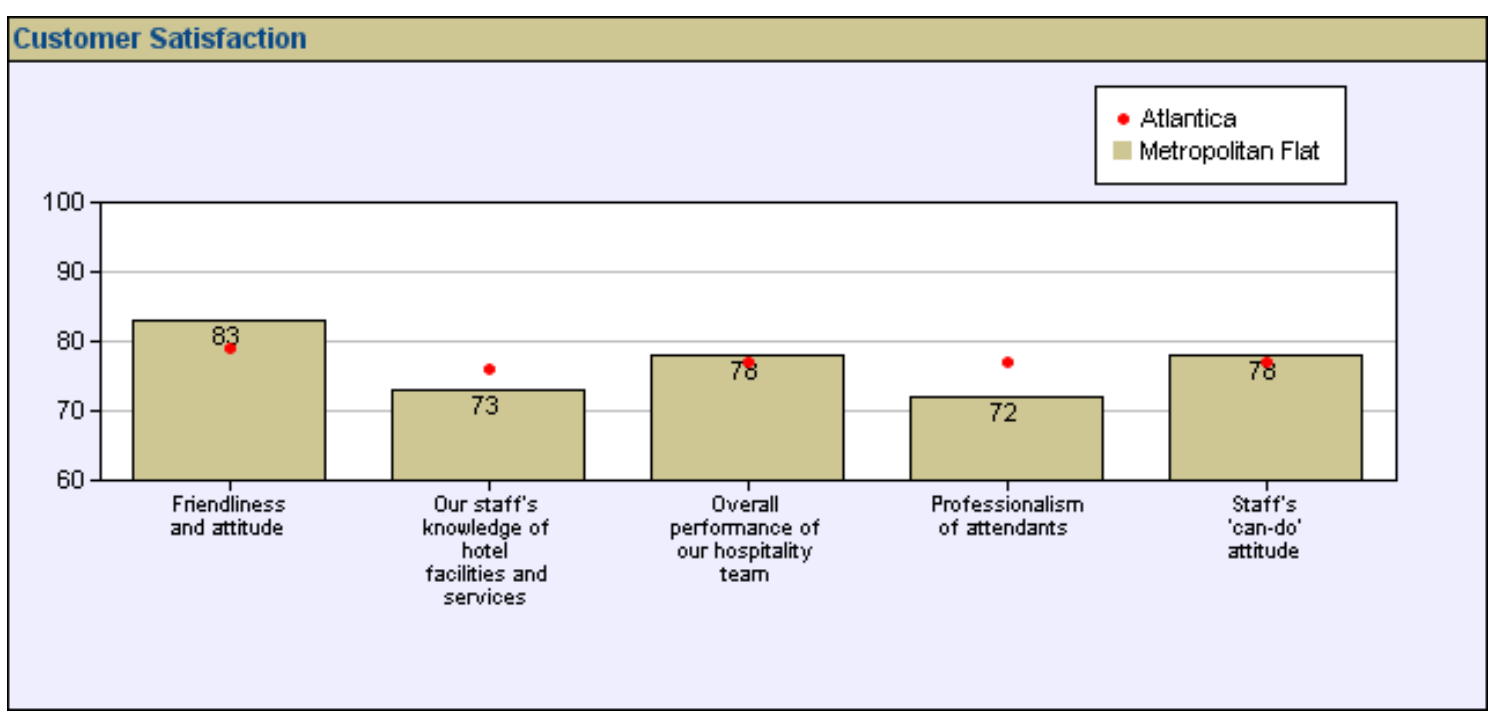

Gráfico 4 - Satisfação do cliente em interação com colaboradores do hotel Metropolitan.

Fonte: Banco de dados Atlantica Hotel - Market Metrix (mar/2007). 


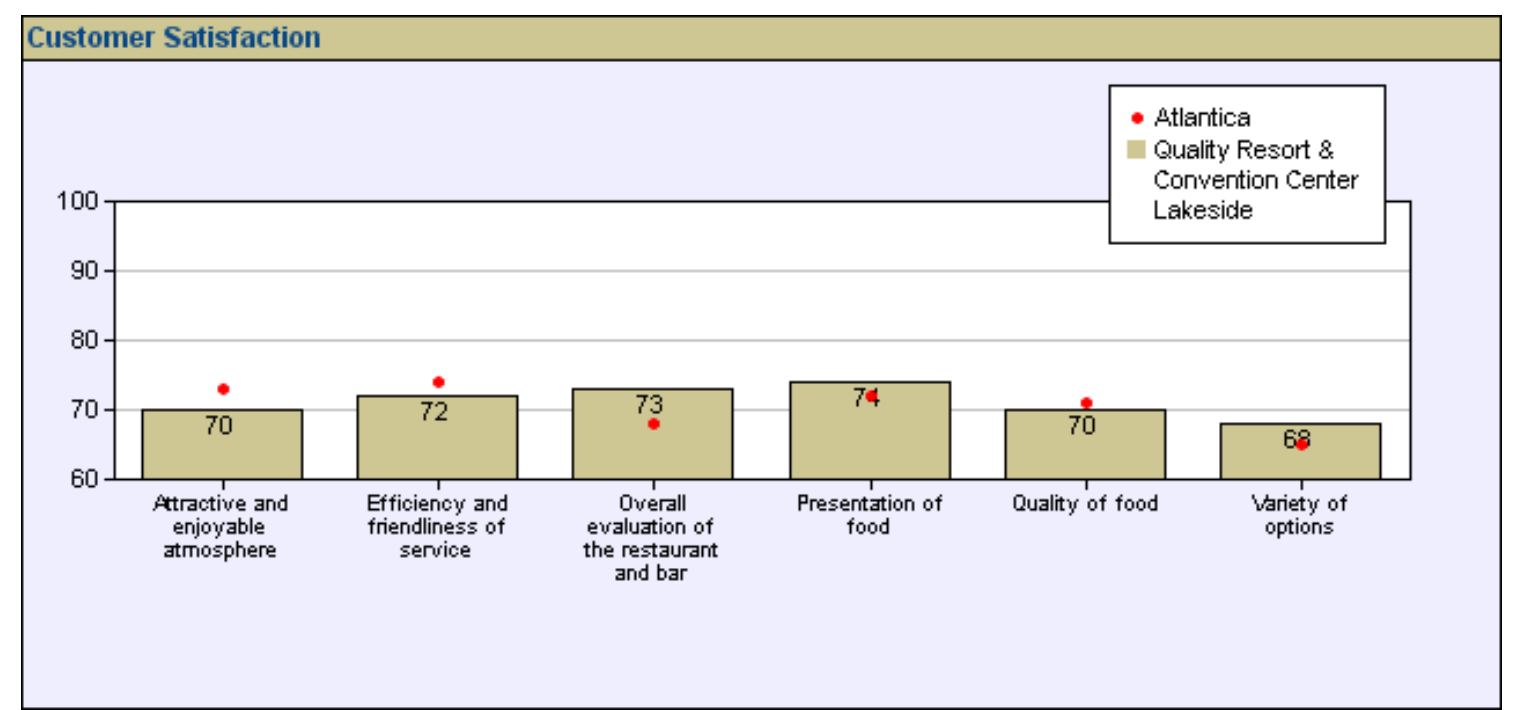

Gráfico 5 - Satisfação dos clientes em situações que não exigem interação direta com o cliente Lakeside Fonte: Banco de dados Atlantica Hotel - Market Metrix (mar/2007).

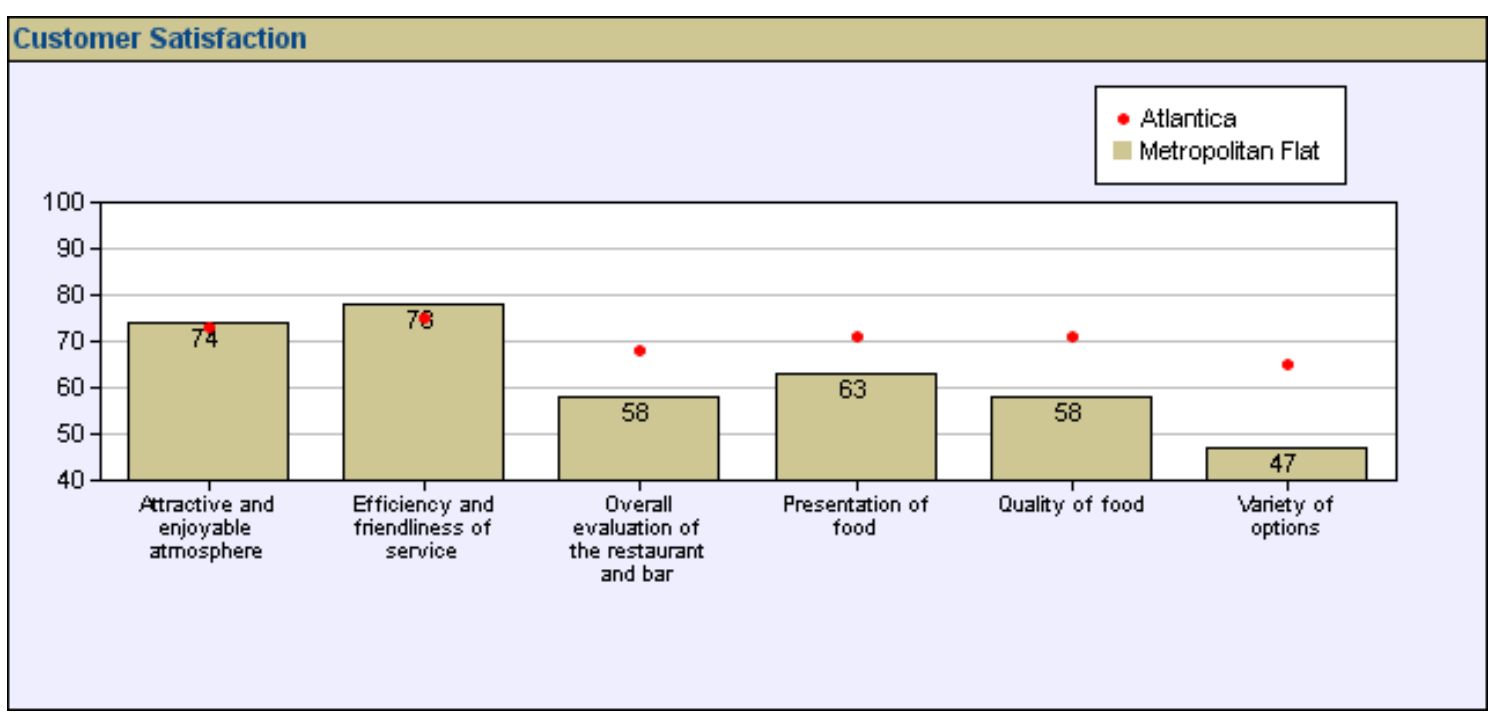

Gráfico 6 - Satisfação dos clientes em situações que não exigem interação direta com o cliente Metropolitan

Fonte: Banco de dados Atlantica Hotel - Market Metrix (mar/2007). 